\title{
Estudo da Variação da Densidade Mamográfica ao Longo de um Ciclo Menstrual
}

\section{Kíssiner Pazuello}

Dissertação apresentada ao Programa de Pós-Graduação Interunidades em Bioengenharia / Escola de Engenharia de São Carlos / Faculdade de Medicina de Ribeirão Preto / Instituto de Química de São Carlos, da Universidade de São Paulo, como parte dos requisitos para obtenção do título de Mestre em Bioengenharia.

\section{Orientador: Prof. Dr. Homero Schiabel}

São Carlos 


\section{Dedicatória}

Este trabalho é dedicado a Deus pelo companheirismo.

É oferecido aos meus filhos: Verena, Guilherme, Fabrício e Tomaz. 


\section{Agradecimentos}

Este trabalho é testemunho da habilidade e criatividade aliado à grande inteligência e paciência do Prof.Dr.Homero Schiabel. No Laboratório de Análise e Digitalização de Imagem da Escola de Engenharia Elétrica de São Carlos ( U.S.P ) contei com muitos amigos, em especial devo reiterar os meus agradecimentos a alguns amigos, como: Claudio, Mauricio, Rodrigo, Marcelo.

Todavia, antes de realizar este trabalho dirigido à mama, alguns nomes são muito marcantes para mim. Pessoas que me ensinaram a operar mama e me fizeram ver na mastologia uma oportunidade de trabalhar crescendo: Prof.Dr.Antonio Figueira Filho; Prof. Dr. Umberto Veronesi; John Haward; Dr.Armando Tejerina.

A parte experimental deste estudo não teria êxito se não fosse o empenho e a técnica do Prof.Dr. Julio Carlos Canola, chefe do Departamento de Radiologia, da Escola de Veterinária de Jaboticabal (U.N.E.S.P), onde fui recebido e contei com a colaboração importantíssima do técnico Paulo.

Um sinal especial de agradecimentos ao Prof.Dr. Wilter Ricardo Russiano Vicente, do Departamento de Reprodução Animal da Escola de Veterinária de Jaboticabal.( U.N.E.S.P). Colaborou do início ao fim deste estudo.

Aos meus professores do Departamento de Bioengenharia de São Carlos (U.S.P): Prof.Dr. Orivaldo Lopez da Silva Prof.Dr. Jose Marcos Alves , Prof. Dr. Luiz Romariz Duarte e Prof . Dr Nelson Ferreira Junior e Prof.Dr. Jose Carlos Pereira

A todas as pacientes do Ambulatório de Mastologia de Matão e de todos os outros ambulatórios que criei.

Aos criadores de caprinos que me cederam os animais: Fernando Cardoso, Guto Vilela e Bia Biagi .

A todas as pessoas que de uma forma direta ou ndireta, colaboraram com este estudo. 


\section{Sumário}

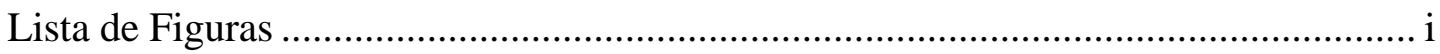

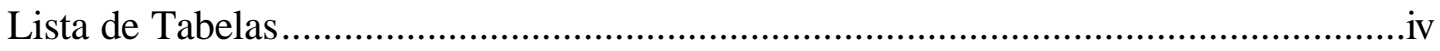

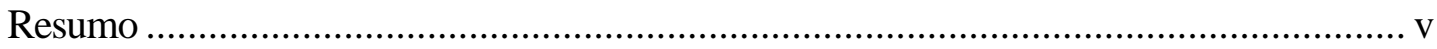

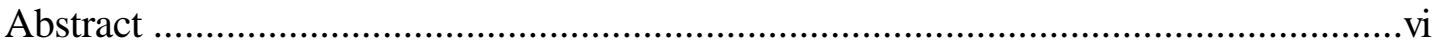

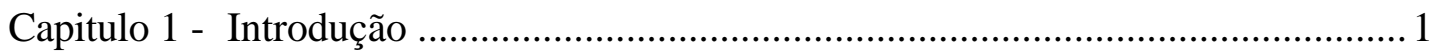

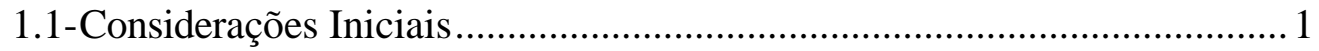

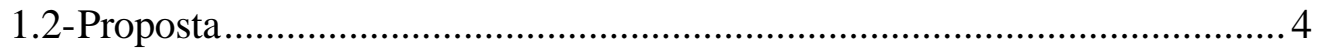

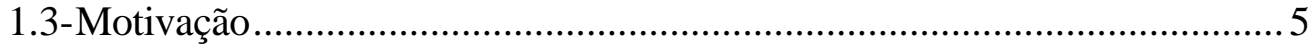

1.4-Disposição do Trabalho ........................................................................... 6

Capítulo-2 - Aspectos Históricos do Câncer de Mama................................................... 7

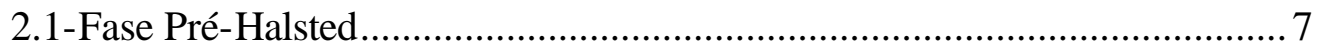

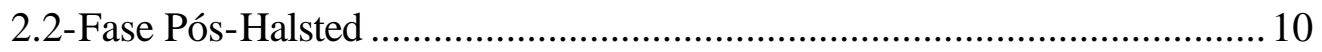

2.3-Aspectos Epidemiológicos do Câncer de Mama....................................... 14

2.4-A Evolução dos Conhecimentos Numéricos do Câncer de Mama .......... 14

2.5-Os Números do Câncer de Mama. ............................................................. 18

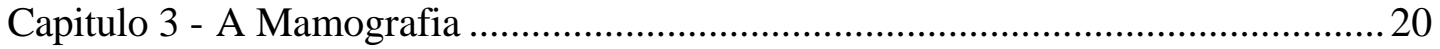

3.1-A Mamografia Como Instrumento Contra o Câncer de Mama ................ 20

3.2-Histórico do Emprego da Mamografia........................................................ 22

3.3-Análise Médica da Mamografia ........................................................... 23

3.3.1 Área de Densidade Aumentada-.................................................... 24

3.3.2 Microcalcificações- .................................................................. 27

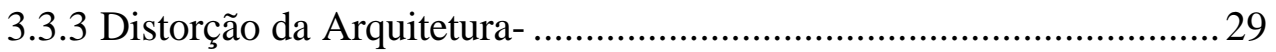

3.3.4 Edema de Pele ou Espessamento de Pele-....................................... 29

3.3.5 Permeação Linfática- ..................................................................... 29

3.3.6 Aumento da Vascularidade- ........................................................... 29

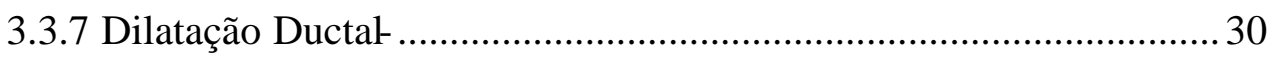

3.3.8 Linfonôdos Comprometidos-............................................................. 30

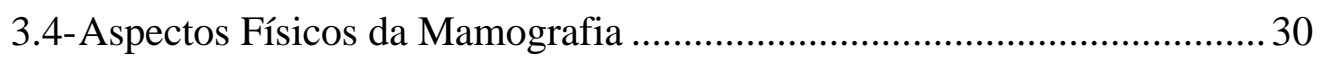

Capítulo 4 - Processamento de Imagem em Mamografia ........................................... 35

4.1-Digitalização de Imagem Mamográfica ................................................. 35

4.2-Processamento de Imagem Mamográfica ................................................ 38

Capitulo.5 - Variações Biológicas da Mama............................................................ 42

5.1-Variações Anatômicas da Mama............................................................ 43 
5.2-Variações Fisiológicas da Mama ao Longo da Vida .44

5.3-Variações Clínicas ao Longo do Ciclo. .46

5.4-Variações do Conteúdo de Água e Sal na Mama ao Longo do Ciclo Menstrual

5.5-Variações Citológicas da Mama ao Longo do Ciclo Menstrual. .48

5.6-Variações da Histologia da Mama ao Longo do Ciclo Menstrua 1............51

5.6.1 I-Fase Proliferativa .52

5.6.2 II-Fase Folicular de Diferenciação .52

5.6.3 III-Fase Luteal de Diferenciação 53

5.6.4 IV-Fase Secretória .53

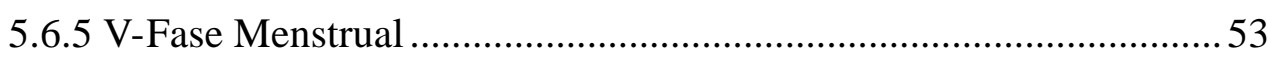

Capitulo 6 - Proposta Geral e Metodologia .............................................................. 55

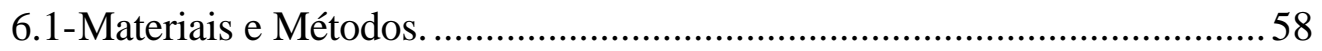

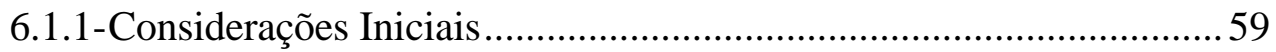

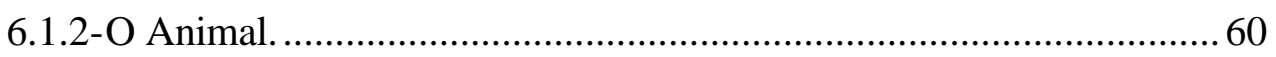

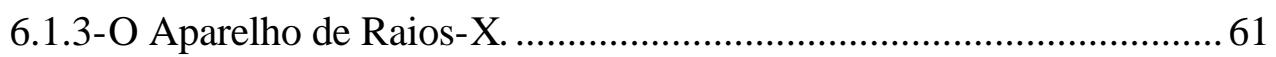

6.1.4-O Instrumento de Compressão da Mama.......................................... 62

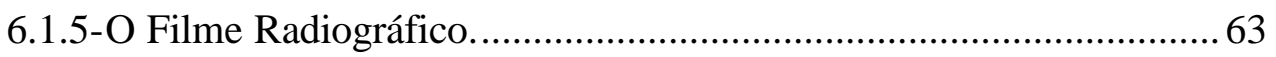

6.1.6-Material de Coleta de Sangue. ........................................................ 63

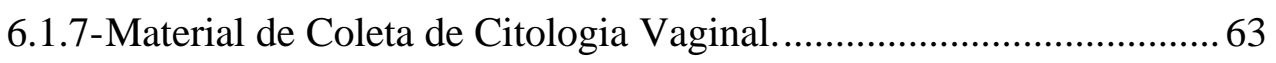

6.2-Método de Aquisição dos Mamogramas da Cabra. ................................. 64

6.3-Método de Aquisição dos Mamogramas Femininos............................... 65

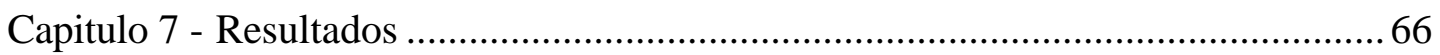

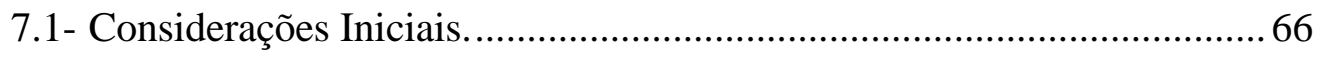

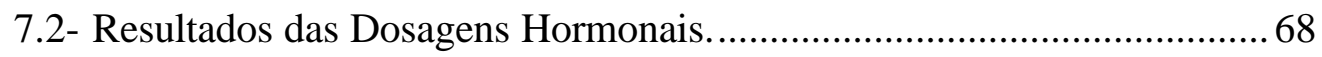

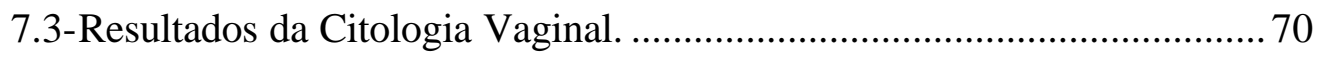

7.4- Exibição das Mamografias Digitalizadas do Animal. ............................ 70

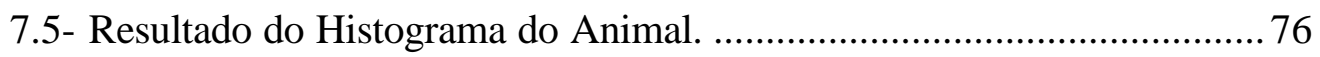

7.6-Avaliação Numérica da Variação da Densidade Mamográfica do Animal.

7.7- Exibição das Mamografias Digitalizadas Femininas. ............................ 82

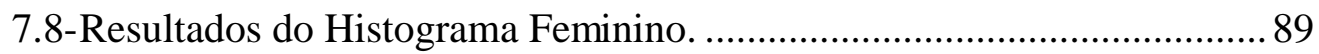

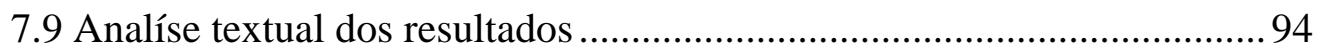

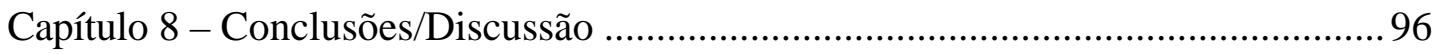

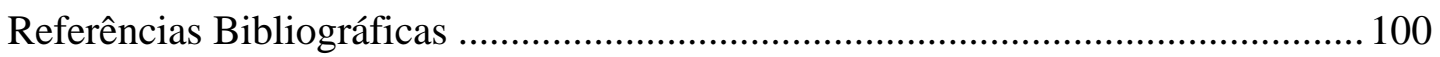

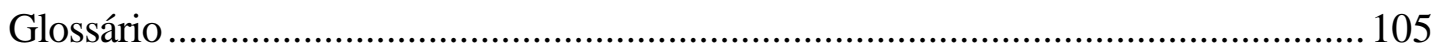




\section{Lista de Figuras}

Figura 3.3-1 Demonstra a freqüência de: (k) adenose tumoral, HAAGENSEN (1987); (Y) carcinoma, GONZALEZ et al.(1986). Segundo a topografia mamaria.. 25

Figura 3.3-2- Demonstra dois cortes do tórax envolvendo a mama. Sendo (1) Corte Vertical e (2) Corte Horizontal. Estão representadas as seguintes estruturas: a) Pele da Mama; b) Gordura Pré-Glandular; c) Espaço Retromamario; d) Costela ; e) Pleura ; f) Pulmão ; g) Ductos Lactíferos. Fonte- TESTUT ...................................... 26

Figura 3.4.1. Contraste entre um tumor de $5 \mathrm{~mm}$ de diâmetro (linha cheia) e uma pequena calcificação (linha tracejada) em função da energia da radiação (HAUS_00). 31

Figura 3.4-2. Espectro de emissão típico de um equipamento mamográfico. Para o alvo de molibdênio (Mo) foi utilizado um filtro de $0,03 \mathrm{~mm}$ de molibdênio e $26 \mathrm{kVp}$ de tensão. Para melhor penetração do feixe, um filtro de ródio (Rh) deve ser utilizado (linha tracejada), (HAUS_00)..... 33

Figura 3.4.3. Imagem de um aparelho mamográfico comercial. 34

Figura 5.2-1. Desenvolvimento da mama: I e II anatômico de frente e de perfil; III esquemático da unidade funcional (ducto e lóbulo);IV aparência nos cortes histológicos. Aqui foram abordadas, as fases: (a) Pré-Púbere, (b) Puberal, (c) Adultas, Gestacionais, Lactantes, Senis. Fonte-BLAND et al .(1994).

Figura 6.1-1- Gráfico esquemático da variação fisiológica dos hormônios Estradiol e Progesterona dos caprinos em 1 ciclo estral, notar que no terceiro dia ocorre a ovulação. Fonte: Chemineau (1993) 61

Figura 6.1-2. A) Fotografia do aparelho compressor da mama e chassi sendo colocado no aparelho.B) Fotografia do aparelho sendo usado na tomada de mamografia, em posição ortostática da cabra. 63

Figura 7.2-1 Representação gráfica dos dados colhidos da dosagem dos hormônios da cabra. Aqui no eixo $\mathrm{X}$ representamos as datas do experimento. 69

Figura-7.4-1. Variação da densidade da mama de acordo com as datas: a) 06/06/2001; b) 07/06/2001; c) 08/06/2001; d) 09/06/2001. 71

Figura-7.4-2. Variação da densidade da mama de acordo com as datas: a) $10 / 06 / 2001$; b) $11 / 06 / 2001$; c) $12 / 06 / 2001$; d) $13 / 06 / 2001$. 72

Figura-7.4-3. Variação da densidade da mama de acordo com as datas: a) $14 / 06 / 2001$; b) $15 / 06 / 2001$; c) $16 / 06 / 2001$; d) $17 / 06 / 2001$. .73

Figura-7.4-4. Variação da densidade da mama de acordo com as datas: a) $18 / 06 / 2001$; b) 19/06/2001; c) 20/06/2001; d) 21/06/2001 .74

Figura-7.4-5. Variação da densidade da mama de acordo com as datas: a) $23 / 06 / 2001$; b) $24 / 06 / 2001$; c) $25 / 06 / 2001$; d) 26/06/2001. 75

Figura-7.4-6 . Variação da densidade da mama de acordo com a data: A) 26/06/01; B) $27 / 06 / 01$;C) $28 / 06 / 01$; D) $29 / 06 / 01$. .76 
Figura 7.5-1 Mamografias do animal realizadas nos dias (a) $10 / 06 / 01$ (b) $15 / 06 / 01$ e seus respectivos histogramas: (c) Histograma da Imagem a; (d) Histograma da imagem $b$.....

Figura 7.5-2 Mamografias do animal realizadas nos dias (a) $21 / 06 / 01$ (b) $26 / 06 / 01$ e seus respectivos histogramas: (c) Histograma da Imagem a; (d) Histograma da imagem (b) .78

Figura-7.5-3. Mamografias do animal realizadas nos dias(a) 27/06/01 ; (b) 28/06/01 e seus respectivos histogramas: (c) histograma da imagem (a); (d) histograma da imagem (b) 79

Figura 7.6-1 Grafico representando a variação dos setores da imagem digitalizada do animal. As cores distinguem os setores. 80

Figura 7.6-2 . Expõe a variação media calculada a partir da media dos valores aferidos em cada setor. 82

Figura 7.7-1 Exibição de dois mamogramas de uma das onze mulheres com a mesma técnica, sendo (a) Fase periovulatória;(b) Fase luteal, do mesmo ciclo. .83

Figura 7.7-2 Exibição de dois mamogramas de uma das onze mulheres com a mesma técnica , sendo (a) Fase periovulatória;(b) Fase luteal , do mesmo ciclo.

Figura 7.7-3 Exibição de dois mamogramas de uma das onze mulheres com a mesma técnica , sendo (a) Fase periovulatória;(b) Fase luteal , do mesmo ciclo.

Figura 7.7-4 Exibição de dois mamogramas de uma das onze mulheres com a mesma técnica , sendo (a) Fase periovulatória;(b) Fase luteal , do mesmo ciclo. 85

Figura 7.7-5 Exibição de dois mamogramas de uma das onze mulheres com a mesma técnica , sendo (a) Fase periovulatória;(b) Fase luteal, do mesmo ciclo.

Figura 7.7-6 Exibição de dois mamogramas de uma das onze mulheres com a mesma técnica , sendo (a) Fase periovulatória;(b) Fase luteal , do mesmo ciclo. 86

Figura 7.7-7 Exibição de dois mamogramas de uma das onze mulheres com a mesma técnica , sendo (a) Fase periovulatória;(b) Fase luteal , do mesmo ciclo. 86

Figura 7.7-8 Exibição de dois mamogramas de uma das onze mulheres com a mesma técnica , sendo (a) Fase periovulatória;(b) Fase luteal, do mesmo ciclo. 87

Figura 7.7-9 Exibição de dois mamogramas de uma das onze mulheres com a mesma técnica , sendo (a) Fase periovulatória;(b) Fase luteal , do mesmo ciclo. 87

Figura 7.7-10 Exibição de dois mamogramas de uma das onze mulheres com a mesma técnica , sendo (a) Fase periovulatória;(b) Fase luteal, do mesmo ciclo. ..... 88

Figura 7.7-11 Exibição de dois mamogramas de uma das onze mulheres com a mesma técnica , sendo (a) Fase periovulatória;(b) Fase luteal , do mesmo ciclo. ...... 88

Figura 7.7-12 Mamografias (a) e (b) e seus respectivos histogramas (c) e (d)......... 89

Figura 7.7-13 Mamografias (a) e (b) e seus respectivos histogramas (c) e (d)......... 90

Figura 7.7-14 Mamografias (a) e (b) e seus respectivos histogramas (c) e (d)......... 91

Figura 7.7-15 Mamografias (a) e (b) e seus respectivos histogramas (c) e (d)......... 92 
Figura 7.7-16 Mamografias (a) e (b) e seus respectivos histogramas (c) e (d)..........93 


\section{Lista de Tabelas}

Tabela 2.2-1. Comparação da casuística de Von Wolkmann e de W.S.Halsted por

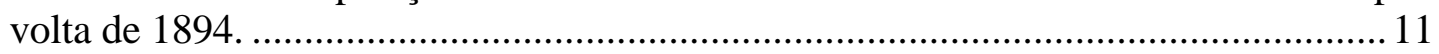

Tabela 2.4.1- Índices mais usados no estudo epidemiológico do câncer de mama ... 16

Tabela 3.3-1 Agrupa os sinais mamográficos do câncer de mama, em sinais

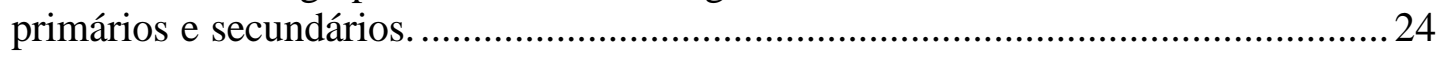

Tabela 5.5-1.Correlação dos achados citológicos de Malberger, segundo as fases por

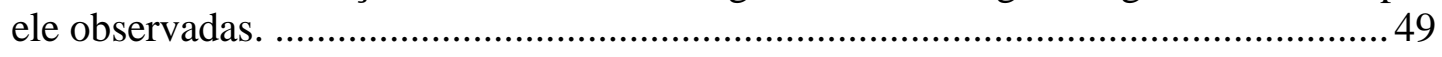

Tabela 7.1 Esposição da Dosagem diária de Estradiol e Progesterona do dia 06/06 até 09/07, indicando a fase do ciclo..... 68

Tabela 7.6-1-Mostra valores aferidos na avaliação dos tons em cada setor, associado aos dias da tomada. 81 


\section{Resumo}

Há muito que se reconhece que a mama não é um orgão estático. Do nascimento à senilidade a mama esta sujeita à variações que vão desde o formato até a composição e arquitetura tecidual.Estas variações são notórias à simples inspeção, palpação, cortes histológicos, dosagens e outros métodos de estudo. Tais variações são decorrentes de fenômenos da esfera endócrina relacionada à vários hormônios envolvidos com o desenvolvimento, tal como: Estrogênios, FSH, LH, TSH, Mineralocorticóides, Prolactina, Progestágenos, Insulina , T3, T4, Glicocorticóides, Hormônio do Crescimento etc. Por outro lado, sabe se também das variações que a mama sofre dentro de apenas um ciclo menstrual decorrentes de fenômenos da esfera endócrina diretamente relacionadas aos hormônios envolvidos com o ciclo menstrual. Por isso, o presente trabalho avalia as implicações cíclicas da mama na qualidade da imagem mamográfica. Para tanto, uma investigação extensiva é feita com exposições radiográficas das mamas de uma cabra a fim de avaliar o perfil das variações de densidade ao longo de um ciclo completo. Inferências dos resultados obtidos são comparadas com algumas mamografias de mulheres, o que comprova a influência e o período em que melhor se pode visibilizar estruturas de interesse no mamograma convencional 


\section{Abstract}

There is known, in long time, that breast is not an static organ. From birth to old age the breast is vulnerable to many variations that come from shape to composition and tissue architecture. This variation is well-know in a single inspection, touching, histological cuts, dosages and many others learning's methods.These variations come from endocrine phenomenon, connected to many hormones that are involved with the breasts development, as this sequence: Estrogenes, FSH, LH, TSH, T3, T4, Glycocorticoids, Growth's Hormones and many others. On the other hand, it's known that the breast's variations during a menstrual cycle come from endocrine phenomenon with a directly connection to the hormones in this cycle. The present work evaluatetes the breast cycle implications to mammographic images quality. For this pourpose, an extensive investigation is been done by using radiographic exposures of an goat breast in orden to evaluate the image density variation pattern thow a complete cycle. The result can ben inferred to some human mammographics showin the influence and period when structures of interest in convencional mammographicies 


\section{Capítulo 1 - Introdução}

\section{1-Considerações Iniciais}

O estudo epidemiológico do câncer de mama, além de revelar conhecimentos numéricos que flagram a face quantitativa desta doença, deve orientar não só a direção das pesquisas, mas também a direção dos investimentos quando o assunto é assistência médica.

Analisando estes dados pode-se anunciar que o câncer de mama é uma doença 100 vezes mais comum entre as mulheres, em relação aos homens. Pode se dizer que os países mais industrializados são atingidos de uma forma mais freqüente do que os países menos industrializados. De uma forma geral, é certo dividir o mundo em três zonas: zona de alta incidência, zona de média incidência e zona de baixa incidência. Precisamente a zona de alta incidência é composta pelos países do norte da Europa, E.U.A e Canadá; já a zona de incidência mediana é composta pelos países do sul da Europa e os países da América Latina. Já na zona de baixa incidência inclui-se o Japão e Singapura. Vale salientar que na zona de baixa incidência, o câncer de mama não é notado de forma a ser encarado como um problema de saúde pública ao contrario da zona mediana e de alta é tida. A análise destes dados, permite fazer enunciados breves, mas de certo peso.

O câncer de mama no ocidente é cinco vezes mais comum do que no oriente. 
No mundo todo, são dados 1.000 .000 de diagnósticos de câncer de mama ao ano.

Especificamente no Brasil, é o câncer de maior índice de mortalidade entre as mulheres.

Mas estes dados são desprovidos de informações que falem a respeito do sofrimento que a mulher acometida experimenta quando comprometida biologicamente com esta doença. Visto assim individualmente, o câncer de mama é muito mais contundente para a mulher.

Grandes esforços são feitos no sentido de interromper a história natural do câncer de mama, visto que não se descreveu ainda um caso de remissão espontânea. Logo, a intervenção terapêutica se faz necessário em 100\% dos casos diagnosticados.

Por outro lado, os conhecimentos sobre o câncer de mama remontam já há quatro milênios. E talvez o mais importante tenha sido percebido e registrado já no papiro de Erbs, por volta de 1500 A.C. em que consta a preocupação com o estágio da doença. Ou seja, já no papiro de Erbs, nota-se uma associação do prognóstico com o estágio da doença. Por conseguinte, há a necessidade de se dar o diagnóstico em estágios iniciais da doença, e se instituir o tratamento prontamente.

Dentre o arsenal de instrumentos que a humanidade conta para diagnosticar o câncer de mama, tem-se a mamografia que há muitos anos vem sendo implementada no sentido de identificar o tumor ainda em dimensões pequenas. Isto numa concepção nítida de que o tamanho do tumor tem associação direta com o estágio da doença. Vale salientar que a mamografia é o exame complementar com maior especificidade para o câncer de mama. Contudo, como exame complementar, este instrumento deve complementar uma hipótese diagnóstica formulada a partir do exame clínico, onde se nota o nódulo. A partir de então, a mamografia investiga a mama.

O mamógrafo é um instrumento que se baseia fundamentalmente na formação da imagem em um filme radiossensível. Tecnicamente o tumor é identificado por uma área circunscritamente mais densa, que fisicamente denota um comportamento diferente do feixe ao atravessar a mama, um fenômeno de subtração desigual e irregular ao longo da mama. Desta forma, a chapa radiossensível deverá registrar apenas os feixes que tiveram êxito em atravessar a mama.Todavia, este fenômeno 
não ocorre nos moldes do "tudo ou nada", mas sim registrando os feixes que foram subtraídos de uma forma parcial. Mais que isto, o sistema empregado pelo mamógrafo admite o registro de feixes num amplo espectro. Uma vez registrado na chapa radiossensível, vislumbram-se áreas mais claras e mais escuras, com fidelidade de posição e tamanho, visto serem os feixes paralelos. Desta forma, tira-se proveito visual e se consegue identificar áreas mais densas e menos densas, com a prerrogativa de localização e com chances destas áreas mais densas estarem relacionadas com o câncer de mama.

Mas as mamas, assim como todo órgão e partes de sistemas biológicos, não são homogêneos e o resultado visual ao examinarmos o mamograma é uma imagem sem comprometimento com a anatomia do órgão, mas sim com a variação de tons de branco ao preto. Assim a análise do mamograma não pressupõe a identificação dos elementos de anatomia micro e macroscópica da mama, tal como em outros exames radiográficos, mas sim a identificação, em meio a esta variação de tons, de área circunscritamente mais densa. A esta variação de tons, que permite distinguir ou identificar área mais e menos densa, atribui se o termo contraste.

Portanto, a identificação do câncer de mama está calcada na capacidade que o tumor sediado na mama tem em se destacar, ou seja, formar o contraste no espectro de branco ao preto, ao longo de uma chapa radiossensível.

Histologicamente a mama é conhecida, assim como os tumores que nela sejam formados. $\mathrm{Na}$ realidade, o tumor é uma variação histológica, citológica e bioquímica do próprio tecido mamário, com distorção da arquitetura tecidual, das organelas celulares e da composição bioquímica da célula. Estes aspectos são muito bem estudados nos cortes histológicos, corados ou impregnados e analisados em microscópios ópticos e eletrônicos. Assim examinados, vê se uma perda da arquitetura tecidual original da mama, que basicamente é a de formação de ductos e lóbulos, para assumir uma arquitetura tecidual bizarra, mas monótona, ou seja, tal arquitetura anárquica assumida pelo tumor é via de regra uma constante ao longo de todo o tumor.

Se histologicamente pode-se dizer que o tumor envereda pr uma arquitetura tecidual anárquica, esta distorção tecidual, citológica e bioquímica, quando estudada pelos fenômenos dos Raios-X, deverá de ser interpretada à luz da variação da 
densidade. Isto é, as mudanças ocorridas no processo de formação do tumor devem ser suficientemente capazes de variar a subtração do feixe de elétrons, a ponto de ser registrado pela chapa radiossensível. Esta variação da subtração deve ser pontual, pois a visualização depende da formação do contraste setorial.

$\mathrm{Na}$ concepção atual da mamografia, tem se a idéia de que a mama, é um órgão estático, insensível às variações pertinentes a um diclo menstrual, que como se sabe, são fundamentalmente dependentes da fisiologia hormonal. Assim, as tomadas de imagens são feitas em qualquer fase do ciclo menstrual. Ou seja, atualmente não se respeita a variação da mama ao longo de um ciclo menstrual, no que tange, à variação da densidade que estas variações podem causar na chapa radiossensível, ao menos, quando se solicita ou se marca o exame mamográfico da paciente.

\section{2-Proposta}

Neste trabalho, pretende-se estudar parcialmente a variação da densidade da mama, ao longo de um ciclo menstrual, com o intuito de identificar um dia, ao longo do ciclo, em que a densidade da mama seja menor e portanto, o contraste seja maior entre o tumor e a mama de histologia habitual. Isto será feito a partir da premissa que tanto a mama como o tumor, respondem à variação fisiológica hormonal, todavia em níveis de tons de branco ao preto diferentes.

O ideal seria dispor de instrumentos capazes de manusear o fator etiológico do câncer de mama, pois assim poder se ia variar a incidência da doença câncer de mama. Porém enquanto aguarda-se estes conhecimentos, segue-se tentando melhorar o prognóstico da mulher acometida pelo câncer de mama. O índice de mortalidade afere este aspecto. Na medida em que melhoramos os índices de mortalidade têm-se a certeza de estarmos caminhando no sentido de mudar o comportamento desta doença. Com este embasamento, o diagnóstico precoce segue sendo a forma mais eficiente de se abordar esta doença.

Calcula-se que possa variar entre 3 a 18 anos, desde a indução do tumor até o diagnóstico clínico. Um outro cálculo importante é que o tumor que se inicia na 
forma dita pré-invasiva demore de 10 a 15 anos para se tornar invasívo, ou seja, tenha potencial de ser sistêmico.

Ao se analisar os gráficos de mortalidade por câncer de mama, entre 1950 e 1980, percebe-se que em todos os países a mortalidade aumentou, embora em níveis discretos. A interpretação destes dados de fato foge ao propósito deste texto, mas deve ficar claro que apesar da mamografia não ter mudado o índice de morte por câncer de mama, é ainda o meio mais eficiente para se diagnosticar o câncer de mama, com potencial de diagnosticar tumores em fases iniciais da doença.

Incrementar a mamografia é uma forma de invadir a fase pré-clínica da doença e assim abordá-la em uma fase em que a cura é mais provável. Difícil dizer se no futuro, será a imagem produzida pelo Raios-X que vai efetivamente diagnosticar o câncer de mama em fase pré-clínica, mas pode-se dizer que em termos atuais, seria a fase de atuação da medicina, para alvejar a cura da doença.

\section{3-Motivação}

O mamógrafo é de fato o grande instrumento com que a medicina conta para diagnosticar o câncer de mama.

Paira sobre o mamógrafo o estigma de que é um exame infalível. São, porém, vários os pontos mais comuns de falhas do exame, que vai desde a concepção do instrumento, até a interpretação. Por outro lado, o número de mulheres envolvidas com o câncer de mama é grande. Estima-se, que nos E.U.A haja 50.000.000 de mulheres portadoras de fatores de risco. O mamógrafo é um instrumento voltado basicamente para a mulher e eventualmente para a paciente de câncer de mama. A rigor, o mamógrafo deveria ser usado em todas as mulheres, de forma periódica.

Por isso, a motivação nesse trabalho flui do interesse em se melhorar o atendimento da mulher com potencial de se transformar em paciente do câncer de mama. 


\section{4-Disposição do Trabalho}

Além do presente capítulo, que denominamos de Introdução, que dimensiona o problema câncer de mama enfocando o diagnóstico, há mais os seguintes capítulos compondo o trabalho:

Capitulo-2: Aspectos Históricos do Câncer de Mama: Narrou se de forma concisa a historia da investida do homem contra o câncer de mama.

Capitulo-3: A Mamografia- Compila se a histórica do emprego da mamografia. Analisando os verdadeiros benefícios que este exame trouxe. Descreve se os princípios de física que rege tal instrumento. Enumera e interpreta se sinais associados ao câncer de mama em uma abordagem médica.

Capitulo-4: Processamento de Imagem em Mamográfica-Aborda se aspectos técnicos relativos á digitalização de mamogramas e processamento de imagem digitalizada.

Capitulo-5: Variação Biológica da Mama- Analisa se a variação da mama ao longo da vida e dentre um ciclo menstrual, no âmbito citológico, histológico e bioquímico.

Capitulo-6:Proposta Geral e Metodologia. Deixa claro uma proposta investigativa da densidade mamográfica e expões o projeto de pesquisa

Capitulo-7:Resultados-Tece comentários sobre os resultados adquiridos e exibe os resultados numéricos e radiográficos digitalizados e tratados, em uma interpretação dos fenômenos á luz da biologia e física.

Capitulo-8: Conclusão. Expões as conclusões de forma explicita e sugere caminhos de pesquisas e de demonstração de fenômenos correlatos.

Capitulo-9: Discussão. Discute-se os resultados frente aos limites e abrangência do próprio experimento. Faz se indicações de redundâncias deste estudo.

Referências Bibliográficas. Em ordem alfa-numérico se lista as obras consultadas e citadas. 


\section{Capítulo-2 - Aspectos Históricos do Câncer de Mama.}

A abordagem histórica de qualquer assunto se faz mister na medida em que se pretende tornar o texto mais lógico e alicerçado em fatos. Neste capítulo, pretende se sedimentar não só o objetivo deste trabalho, que é a idéia de que a imagem da mama no filme radiográfico varia ao longo do ciclo menstrual, mas dar a devida importância a isto, assim como justificar alguns aspectos concernentes ao câncer de mama, quer seja no âmbito do diagnóstico, quer seja no âmbito dos instrumentos terapêuticos usados na atualidade.

Deve-se deixar claro que o câncer de mama em si não tem história, pois o seu biologismo admite-se ser o mesmo com o passar do tempo, isto é, o biologismo do tumor de 2000 anos atrás é o mesmo biologismo de hoje. Na realidade, pretende se narrar os fatos relevantes das investidas dos homens contra esta doença, no ambiente científico.

\section{1-Fase Pré-Halsted}

O câncer na mama já foi registrado por volta de 2000 anos a.C. Em 1862 Edwin Smith encontrou o chamado papiro cirúrgico, em Tebas, Egito. Trata se de um rolo de 4,5 m gravado em ambos os lados, em que se faz menção às doenças da mama tal como abscessos e tumores ulcerados assim como traumatismos. Propõe o uso de cautério, e deixa clara a diferença entre o abscesso e o tumor. Por volta de 1500 anos a.C, foi gravado ou pintado o papiro de Ebers. Neste fica claro o uso da 
faca como instrumento de tratamento do câncer de mama, e ainda faz menção aos linfonôdos axilares, no que tange ao prognóstico da paciente portadora do câncer de mama: "Aqui a cirurgia não pode atuar e a morte vem" (BLAND et al (1994); GONZÁLEZ et al (1986) ; URIBURU(1986))

Vale salientar que a medicina nesta fase da história do Egito era bastante limitada em termos de especulação, pois os cirurgiões eram obrigados a, antes de iniciar o tratamento, fazer uma previsão com relação ao sucesso do tratamento proposto e a abordagem cirúrgica era sempre com uso de facas afiadas e cauterização. Nesta fase não se tinha concessão ao insucesso. Ou ele aguardava a evolução da doença, ou tratava e se comprometia com o sucesso ou ele se negava a tratar. Estes aspectos desestimularam a prática médica inclusive tolhia a observação, tão importante no ímpeto científico. Muitos médicos egípcios, mudaram-se para a Grécia a fim de estudar. (BLAND et al (1994))

Hipócrates (460-370 a.C), na Grécia, teorizava quatro humores: sangue, flegma, bile amarela e bile negra. A doença e a saúde dependiam destes humores e a proposta era de um equilíbrio entre eles. Hipócrates dividiu as doenças em três categorias, as que a medicina curava, as doenças que a medicina não curava, mas a faca curava, e as que nem medicina e nem a faca curavam, mas o fogo curava. Hipócrates escreveu bastante, mas pouco sobre as mamas, e um desses poucos relatos, menciona o derrame papilar mamário e associa-o ao carcinoma de mama, relatando morte da paciente quando o derrame cessou. Associou o fim da menstruação com o carcinoma e com os nódulos de mama. Mas o mais importante escrito deixado por Hipocrates sobre o câncer de mama é a noção da inviabilidade do tratamento para tumores avançados e profundamente localizados. Talvez tenha sido este o primeiro posicionamento clássico, com relação ao câncer de mama, que tenha confrontado a proposta terapêutica com o prognóstico. ((BLAND et al (1994); URIBURU(1986).)

A primeira descrição clínica do câncer de mama, deve-se a um enciclopedista e não médico, no primeiro século da era cristã: Aurélio Cornélio Celso, romano, descreve as tumorações endurecidas ou amolecidas e irregulares das mamas femininas e classifica os tumores das mamas em quatro fases: malignidade (inicial), carcinoma sem úlcera, câncer ulcerado e câncer ulcerado vegetante. Neste mesmo 
tratado, Aurélio desaconselha o tratamento em estágios mais avançados, tal como nos três últimos, justificando que o tratamento nestas fases causariam mais recidiva por irritarem os tecidos.(.BLAND et al (1994))

Galeno (131-201 d.C) médico reconhecido em Roma, seguidor de Hipócrates, notou a semelhança dos tumores malignos de mama com as patas do caranguejo, na sua forma invasiva. Este aspecto foi de uso comum ao resto do organismo quanto ao termo câncer, para definir tumores que invadem, e portanto são malignos. (BLAND et al (1994); GONZALEZ et al (1986))

Os ensinamentos de Hipócrates e Galeno somente foram abalados por volta de 1550, quando Andrés Vesallius, um anatomista e cirurgião de Bruxelas, rejeitava veementemente a anatomia comparada, tão praticada por Galeno. Com relação ao câncer de mama, Vesalius indicava a excisão da mama e ligadura dos vasos sangrantes e não o uso do cautério, ou óleo quente. Neste mesmo século, Francisco Arceo publica o primeiro relato sobre o câncer de mama no homem. Michel Servet, espanhol que estudou na França, nesse mesmo século, faz menção à importância da retirada dos linfonôdos axilares e ainda propõe a retirada do músculo grande peitoral.(BLAND et al (1994) ; URIBURU (1986))

O século XVll pode ser lembrado pela presença de dois grandes cirurgiões e de alguns avanços no tratamento e entendimento do câncer de mama, incorporandose ao assunto alguns conceitos de peso. Le Dran estabeleceu a via linfática como fator de disseminação do câncer de mama. Já Louis Petit descreve a mastectomia com esvaziamento axilar e formaliza o prognóstico baseado no comprometimento linfonôdal. Louis Petit, ainda descreve o comprometimento ósseo no câncer de mama em sua forma metastática.(BLAND et al(1994); URIBURU(1986)).

Nem todos os cirurgiões da época viam resultados compensatórios em se realizar tais cirurgias. Afinal, os números eram desencorajadores. Em 1853 foi publicado um trabalho por Alfred Armand Louis Velpeaul, que demonstrava que ao término de cinco anos somente 7 pacientes estavam vivas, de um universo de 170 casos operados de câncer de mama. Robert Liston, cirurgião de Londres, desaconselhava a busca dos linfonôdos axilares, por entender ser este procedimento por demais cruel. E assim outros trabalhos apontavam para maus resultados da cirurgia de câncer de mama. Os benefícios na realidade eram duvidosos, pelo menos 
numericamente demonstrados. Fato é que, embora na primeira metade do século XVIll o número de mastectomias fosse grande, no final desse século esse número já tinha reduzido bastante. Tanto a população como a classe cientifica via desfilar as mutilações e os números desencorajadores que serviam como desestímulo à prática da cirurgia do câncer de mama. (BLAND et al (1994); GONZALEZ (1986); HAAGENSEN (1987).)

$\mathrm{O}$ começo do século $\mathrm{XIX}$ se caracteriza por se entender a diferenciação entre os processos malignos e benignos da mama como uma resposta da ciência ao descrédito das empreitadas contra o câncer de mama do século XV1ll. Astley Paston Cooper deixa clara a benignidade do fibroadenoma, descreve a tuberculose mamaria, e realça os descaminhos que a cirurgia da mama tinha tomado. Deixa claro que muitas mulheres tinham sido operadas sem a menor necessidade, pois, ao invés de câncer, muitas lesões operadas eram na verdade benignas. Logo, muitas mulheres tinham morrido de forma desnecessária, assim como muito sofrimento fora causado em vão, simplesmente por se desconhecer a natureza benigna de certas lesões. (BLAND et al(1994).)

Athanase Leon Gosselin, em 1873, publicou uma classificação das doenças malignas da mama, em que pode-se identificar uma tentativa de se classificar os tipos clínicos do câncer de mama: câncer bilobulado com eczema eritematoso ao redor do mamilo, câncer galopante, câncer em couraça, câncer ulcerado, etc. Note-se que já nesta época já se tentava diferenciar as apresentações da doença câncer de mama, pelo menos clinicamente. Dubar em 1881 descreveu com detalhes a anatomia patológica mamária iniciando o entendimento microscópico da patologia mamária, de fundamental importância para o diagnóstico do câncer de mama, visto ser um importante parâmetro que determina o procedimento terapêutico a ser tomado. (BLAND et al (1994))

\section{2-Fase Pós-Halsted}

No Roosevelt Hospital em Nova Iorque, W.S. Halsted fez a primeira mastectomia radical em 1882 e passou a perseguir os números de Richard Von 
Wolkmann, que tinha grande mortalidade intra-operatória, grande número de recidivas locais e pequenos números de sobrevivência ao final de 3 anos. (HAAGENSEN ( 1987)). Só para termos uma perfeita noção deste momento histórico, pode-se dizer que o mundo praticava a cirurgia de Richard Von Wolkmann, no final do século XIX e, por conseguinte, experimentava as suas estatísticas. Halsted mudou o procedimento ao melhorar a técnica cirúrgica e torná-la mais ampla. Publicou trabalho em 1894 realizado em cima de uma casuística de 50 casos operados ao longo de 12 anos em que divulgou os seguintes números: mortes intra operatórias: zero; recidiva ao final de 3 anos: 6\%; número de pacientes livres da doença no final de 3 anos:50\%.(GONZALEZ (1986)).

Tabela 2.2-1. Comparação da casuística de Von Wolkmann e de W.S.Halsted por volta de 1894.

\begin{tabular}{|c|c|c|c|}
\hline & $\begin{array}{c}\text { Mortalidade intra- } \\
\text { operatória }\end{array}$ & $\begin{array}{c}\text { Recidiva após } \\
\text { três anos }\end{array}$ & $\begin{array}{c}\text { Porcentagem de } \\
\text { pacientes vivas } \\
\text { após três anos de } \\
\text { cirurgia }\end{array}$ \\
\hline $\begin{array}{c}\text { Casuística de } \\
\text { Richard von } \\
\text { Wolkmann } \\
\text { publicado em 1876 }\end{array}$ & $18,7 \%$ & $82 \%$ & $4,7 \%$ \\
\hline $\begin{array}{c}\text { Casuística de } \\
\text { Willian Stuart } \\
\text { Halsted publicado } \\
\text { em 1894 }\end{array}$ & Zero & $6 \%$ & $50 \%$ \\
\hline
\end{tabular}

A tabela 2.2-1 deixa claro o motivo pelo qual o mundo atual considera W.S. Halsted o pai da cirurgia para o câncer de mama, pois na realidade apresentou números consistentes de melhoria do tratamento.

O tratamento do câncer de mama recebeu, a partir da segunda metade do século XIX, grandes contribuições. No início do século XX, o tratamento do câncer de mama tinha recebido as suas sustentações mais importantes, que eram a diminuição da mortalidade intra-operatória através do controle da hemorragia, menos infecção pós-operatória e um tratamento com menos dor.( BLAND et al(1994).) 
No início do século XX, o diagnóstico era puramente ocasional, a maioria das pacientes que se submetiam ao tratamento do câncer de mama, tinha o diagnóstico dado em fase tardia da doença, visto que nesta época, não se conhecia nem mesmo o auto-exame das mamas. Apesar de os conhecimentos de que essa doença, a partir de um determinado estágio, é sistêmica, o tratamento seguia sendo o mesmo para todos os casos. Isto teve como consequiência um mau uso da cirurgia de Halsted, quando se avaliava de forma científica os índices de sobrevivência das pacientes. Notou-se que a cirurgia de Halsted era pequena para alguns casos, e grande para outros. Alguns outros conhecimentos contribuíram para se refletir melhor com relação à indicação da cirurgia do câncer de mama. O conhecimento do mecanismo de metástase e da história natural da doença foram de fundamental importância para se tentar novas cirurgias.

Uma preocupação que surge também nesta mesma época é com o desfiguramento corporal a que as pacientes estavam sujeitas, quando submetidas ao tratamento. Em 1895 Vincenz e Czerny fazem a primeira reconstrução de mama usando um lipoma. Em 1896 Tanisini na Universidade de Pádua faz a primeira reconstrução de mama usando o retalho miocutâneo dorsal. Em 1954 usou-se a esponja de Ivalon, introduzida por Pagman e Wallace. Em 1963, Cronin e Gerow usaram o silicone, como instrumento de reconstrução das deformidades causadas pelas mastectomias. (BLAND et al(1994)).

Umberto Veronesi, em Milão, em 1968 fez à OMS uma proposta de se iniciar em vários centros do mundo um protocolo que tentava concluir com relação a uma cirurgia mais conservadora para o câncer de mama inicial. Após várias reuniões, concluiu-se que os institutos de Moscou, Paris, Budapeste, Londres e Milão participariam da investigação. A proposta era de se fazer tumorectomia ampla com ampla dissecção axilar, o que recebeu o nome de quadrantectomia. Os serviços de Moscou, Londres, Budapeste e Paris não levaram a termo o projeto, mas Milão concluiu ser um procedimento escolhido para tumores menores de $2 \mathrm{~cm}$. Em 1981 os resultados foram publicados na mais importante revista médica do mundo, New England Journal of Medicine, e divulgados subseqüentemente na primeira página do New York Times, em 2 de julho de 1981. ( HAAGENSEN (1987); VERONESI at al (1992).) 
Os Raios-x foram descobertos em 1895 por Wilhelm Conrad Roentgen, e após 2 meses, um estudante de medicina de Chicago, Emile Grubbe, iniciou o seu uso com finalidades terapêuticas em uma paciente portadora de câncer de mama. (BLAND et al (1994); HAAGENSEN (1987)). O efeito inibidor da divisão celular provocado pela radiação, foi descrito pela primeira vez em 1903, por Georg Clemens Perthes. (BLAND et al. (1994)).

Apesar de não se ter controle da dose, o uso da radiação- $X$ tornou-se convencional para casos avançados desde o começo do século XX, com efeitos indesejáveis tais como: vesiculação, eritema, depilação e necrose. Não se conhecia a totalidade dos efeitos da radiação ainda em 1919, quando o mundo tinha uma lista de 169 médicos comprometidos biologicamente por trabalhar com radiação. BLAND et al (1994).

Em 1920 a Radioterapia foi reconhecida como especialidade médica. Nesta mesma época, extende-se o uso da radiação ionizante à mastectomia, como forma de combater as células neoplásicas residuais. Em 1932 Geoffrey Langdon Keynes em Londres, usa o rádio como fonte de radiação e consegue uma sobrevida de $77 \%$ sem comprometimento linfonôdal axilar e 36\% com comprometimento linfonodal axilar, ao término de 5 anos. (BLAND et al (1994); HAAGENSEN (1987)).

Por volta de 1952 surgiram trabalhos que demonstravam microscopicamente os efeitos da radiação no câncer de mama. Nos anos de 1960 adicionou-se o Cobalto como fonte de radiação, e o Irídio implantado na mama, com resultados cosméticos animadores, e menor incidência de complicação pós-radioterapia. (BLAND et al (1994); HAAGENSEN (1987).)

Por volta de 1913 Salomon na Alemanha radiografou 3000 produtos de mastectomias, demonstrando a forma cirrosa e nodular do câncer de mama e verificou as microcalcificações, porém não as-associou ainda com o câncer de mama. (BLAND et al. (1994); HAAGENSEN (1987)).

Egan em 1962, publicou trabalhos que davam ênfase ao diagnóstico diferencial de doenças benignas e malignas através da mamografia. Este método sofreu aperfeiçoamentos culminando com o uso de menor dose, o que diminuiu o medo de indução de câncer de mama. (HAAGENSEN (1987)). 
Witten e Thurber da Clinica Mayo, relataram em 1964, uma casuística de 5014 pacientes com carcinoma de mama, todavia somente em 8 pacientes foi dado o diagnóstico pela mamografia, o que desestimulou o seu uso. Outro trabalho que desestimulou o uso do método como forma de se dar o diagnóstico de câncer de mama, foi o trabalho publicado por Stevens e Weigen, em 1966, quando relataram ter encontrado somente 8 carcinomas em 1233 pacientes.( HAAGENSEN (1987)).

A mamografia, no entanto, tem sido aperfeiçoada a ponto de atualmente ser o exame complementar de eleição para se detectar o câncer de mama, assim como para melhor caracterizar lesões palpáveis de mama, como forma de se planejar o tratamento e se estimar o prognóstico. (BLAND et al. (1994); HAAGENSEN (1987)).

\section{3-Aspectos Epidemiológicos do Câncer de Mama}

O conhecimento quantitativo do câncer de mama é relativamente recente assim como a concepção de que estes dados são importantes. Na realidade são estes conhecimentos que orientam não só os investimentos na assistência à saúde como orientam a aquisição de conhecimentos, em forma de trabalhos científicos.

A matéria é de cunho estatístico, e trabalha com dados numéricos, colhidos em fontes diversas, que vão desde instituições educadoras como universidades, até instituições comerciais, tal como laboratórios de patologia.

No que tange ao câncer de mama, a Organização Mundial de Saúde tem tentado uniformizar a colheita destes dados.

\section{4-A Evolução dos Conhecimentos Numéricos do Câncer de Mama}


Nos EUA, por volta de 1900, o órgão chamado Oficina do Censo publicou dados sobre mortalidade. Os dados desta época apontam para uma mortalidade do câncer de mama, por volta de 13,5 por 100.000 mulheres ao ano em 13 Estados e em 1930 a mortalidade aferida foi de 23,2 por 100.000 mulheres ao ano, já com todos os Estados envolvidos. Estes são historicamente os primeiros números publicados do câncer de mama. (BLAND et al.(1994); GONZALEZ et al (1986); HAAGENSEN.(1987)).

Em 1957 a Organização Mundial da Saúde publicou dados específicos da mortalidade por câncer de mama, comparando dados de 1936/38 com dados de 1952/54. Desde 1962, esta organização, publica dados de mortalidade do câncer de mama em um documento chamado:Anuário Mundial de Estatística de Saúde, compilando informações de 60 países.(BLAND et al.(1994); HAAGENSEN.(1987)).

Um outro índice importante do câncer de mama é a distribuição das mortes segundo a idade, em períodos de 5 anos. Este dado é expresso em gráfico e permite avaliar a faixa etária em que a morte mais ocorre. Em 1942, surge na Dinamarca o índice de incidência anual, ou índice de morbidade anual vinculado ao câncer de mama. Em 1960, Segi et al, iniciaram a publicação de índice de mortalidade que leva em evidência o órgão em que ocorre primariamente o câncer, permitindo então avaliar a incidência de morte relativa a cada órgão. (GONZALEZ et al. (1986); HAAGENSEN.(1987)).

De um modo geral, os números do câncer de mama são expressos por 6 índices: Índice de Morte Anual; Índice de Morte Anual por Faixa Etária; Índice de Morte Anual ao Longo do Tempo; Índice de Morbidade ou Índice de Incidência Anual; Índice de Enfermas Constantes; Índice de Morte por Câncer de Cada Órgão.Na tabela 2.4.1 elencamos e definimos tais índices. $\mathrm{O}$ índice de mortalidade anual é de fato o índice que melhor expressa o tamanho da doença, e pode ser representado de varias formas. A forma exposta em gráfico permite uma comparação visual de cada espaço geográfico. 
Tabela 2.4.1 - Índices mais usados no estudo epidemiológico do câncer de mama

\begin{tabular}{|c|c|}
\hline Índice de Morte Anual & $\begin{array}{l}\text { É o número de mortes que ocorrem em } 1 \\
\text { ano em relação a } 100.000 \text { mulheres. }\end{array}$ \\
\hline $\begin{array}{c}\text { Índice de Morte Anual por Faixa } \\
\text { Etária }\end{array}$ & $\begin{array}{l}\text { É a distribuição das mortes em períodos } \\
\text { de } 5 \text { anos, ao longo de uma escala etária. }\end{array}$ \\
\hline $\begin{array}{l}\text { Índice de Morte Anual ao Longo do } \\
\text { Tempo }\end{array}$ & $\begin{array}{l}\text { É o Índice de Morte Anual por } 100.000 \\
\text { mulheres em } 1 \text { ano ao longo do tempo. }\end{array}$ \\
\hline $\begin{array}{l}\text { Índice de Morbidade ou Índice de } \\
\text { Incidência Anual }\end{array}$ & $\begin{array}{l}\text { É o número de casos novos que surgem } \\
\text { em } 100.000 \text { mulheres em } 1 \text { ano. } \\
\text { Multiplica se o índice de mortalidade } \\
\text { anual pelo fator } 2,7\end{array}$ \\
\hline Índice de Enfermas Constantes & $\begin{array}{l}\text { É o número de mulheres que em um } \\
\text { determinado momento esta em } \\
\text { tratamento. Multiplica se o índice de } \\
\text { morbidade pelo fator } 6 \text {. }\end{array}$ \\
\hline $\begin{array}{l}\text { Índice de Morte por Câncer de Cada } \\
\text { Órgão. }\end{array}$ & $\begin{array}{l}\text { É o índice de morte por câncer causado } \\
\text { por determinado órgão ao longo do } \\
\text { tempo. }\end{array}$ \\
\hline
\end{tabular}




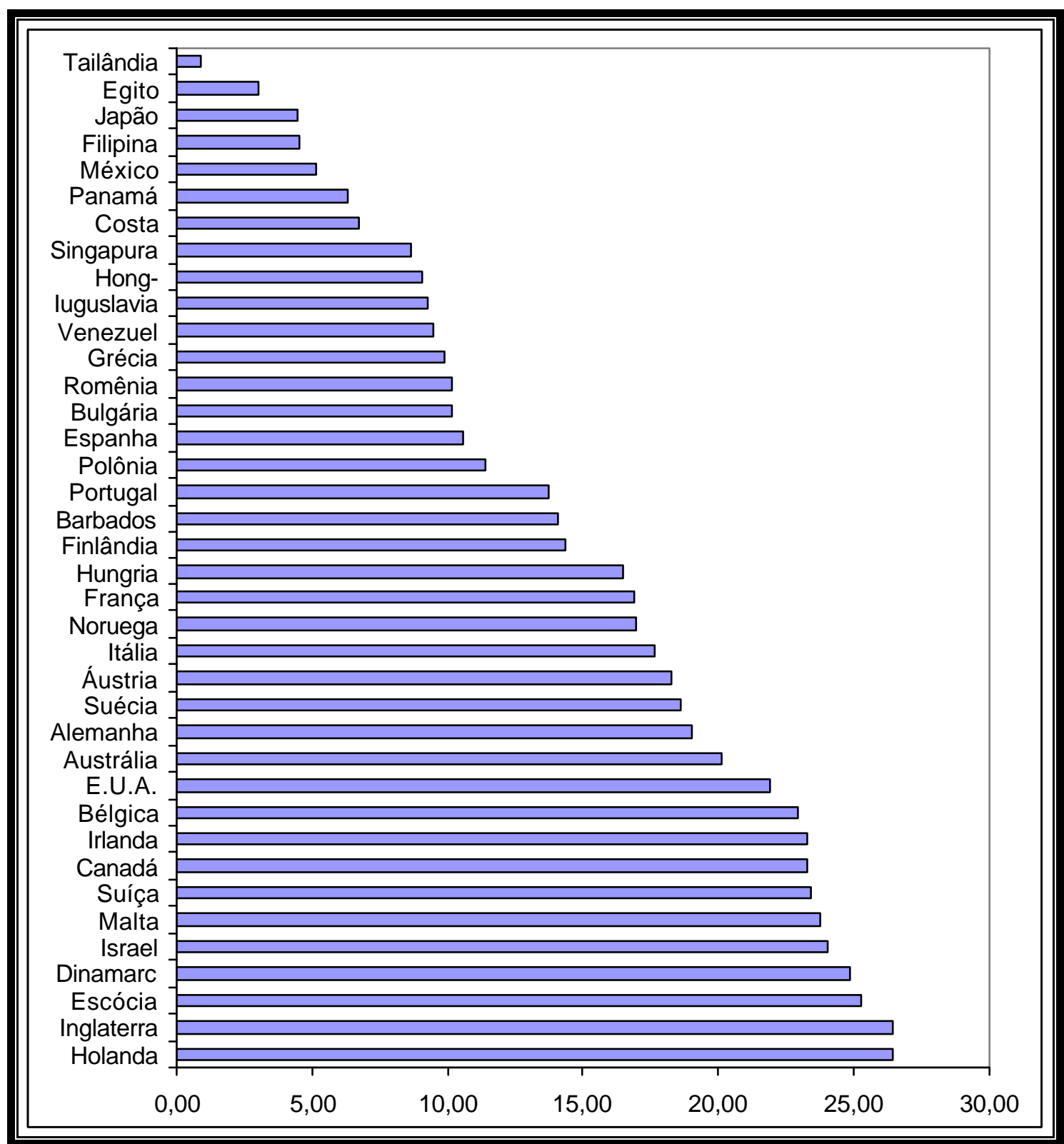

Figura 2.4.1-Demonstração gráfica dos índices de mortalidade anual por câncer de mama em vários países. No eixo (X) temos os índices e no eixo (Y) os respectivos países. FonteHaagensen(1987).

A representação gráfica do índice de mortalidade por câncer de mama deixa clara a variação deste índice entre países, figura 2.4.1. Fica evidente também que o planisfério pode ser dividido em três zonas quanto à incidência do câncer de mama: incidência alta, incidência mediana e incidência baixa. 


\section{5-Os Números do Câncer de Mama.}

$\mathrm{Na}$ realidade o câncer de mama é encarado como sendo um problema de saúde pública mundial. É a primeira causa de morte por câncer em mulheres. É a terceira causa de morte por câncer nos humanos, sendo superado somente pelo câncer de pulmão e de estômago. Foi responsável por 500.000 mortes no ano 2000 no mundo todo. Por volta do ano 2000 teve se 1.000 .000 de casos novos diagnosticados no mundo todo. Nos EUA, em cada 500 mulheres ocorre um caso de câncer de mama a cada ano, em mulheres acima de 35 nos, isto é 100.000 casos novos por ano sobre 50.000.000 de mulheres do grupo de risco. O câncer de mama oferece uma predileção pelos paises industrializados. É uma doença do Ocidente que cursa com uma proporção de 5:1 em relação ao Oriente. (BLAND et al. (1994)).

Alguns fatos induzem às grandes reflexões. $O$ fato de $o$ Japão ser industrializado e ter uma tendência pequena para o câncer de mama desmonta a idéia de que um fator ambiental associado à industrialização seja responsável pela alta incidência de câncer em países industrializados.(BLAND et al.(1994)). O fato de terse na Índia regiões em que o ambiente é o mesmo, mas a crença é diferente, com índices diferentes para câncer de mama, é capaz de tornar o assunto extremamente polêmico. De forma objetiva, os números de Grande Bobain, na Índia são: se o grupo de mulheres estudado for de cristãs o índice de incidência é de 31, se for muçulmana 24,4, se for hindú é de 18,4. O próprio Estado de Israel experimenta índices diferentes de câncer de mama ao se analisar mulheres de crença hebraica e de crença não hebraica. Mulheres judias que moram em Tel Aviv, têm um índice de morbidade de 65, mas para mulheres de Tel Aviv que não são judias, o índice de morbidade é de 10. Katz et al, estudaram o comportamento destes índices aproveitando a migração para Israel de povos vindos da Europa, Ásia e África. Detectaram um incremento nos índices dos povos que vieram da África, diferente do incremento dos povos que vieram da Europa, para os migrantes europeus somente houve um incremento de $12 \%$, ao passo que para as mulheres que vieram da Ásia e África o incremento foi de 54\%. Estes números são bastante distantes e fora da 
margem de erro.(BLAND. et al.(1994); GONZALEZ et al.(1986); HAAGENSEN. 1987)).

$\mathrm{O}$ assunto torna-se mais intrigante quando se analisa o caso das migrantes para os EUA. Por exemplo: mulheres de Varsóvia que migraram para os EUA, assimilaram os índices americanos de câncer de mama, mas isto se deu em 10 anos, ao passo que as japonesas que migraram demoraram menos tempo para adquirir os índices americanos. Aliás, a segunda geração tem índices muito próximos ao americano, quando se analisam imigrações para os EUA. Este fato ilustra e colabora com a idéia de que existe um fator ambiental e um fator cultural. (HAAGENSEN. ( 1987)). 


\section{Capitulo 3 - A Mamografia}

A interpretação da mamografia se faz no sentido de se identificar principalmente o câncer de mama, seja em que fase estiver. Esta análise é uma prerrogativa médica, e só aos médicos é dado o direito de interpretar as mamografias, de forma profissional. A Sociedade Brasileira de Mastologia tem expedido um documento aos mastologistas que querem se habilitar em analisar mamografias, após prova teórica e prática, devidamente concebidos pelo Conselho Federal de Medicina. Já aos radiologistas este direito é pertinente à sua especialização.

\section{1-A Mamografia Como Instrumento Contra o Câncer de Mama}

Ainda em 1964, a Clinica Mayo publicou um trabalho que denotava um desestímulo ao emprego da mamografia. Este trabalho exibia uma casuística desanimadora, pois, após mamografar uma única vez 5014 mulheres, conseguiu-se dar o diagnóstico de câncer de mama somente em 8. Outra face do problema que é discriminante para o uso da mamografia, é o perigo de indução de câncer de mama através da investigação da mama pelos Raios-X.( HAAGENSEN.(1987)).

Mc Gregor em 1977 estudou o comportamento epidemiológico do câncer de mama entre mulheres expostas às radiações no evento bélico de Nagasaki e Hiroshima, ocorrido em 1945. De 1945 até 1969 registraram-se 192 carcinomas de mama em um universo de 11.968 mulheres expostas. A idade de corte foi de 10 anos. Notou que a incidência de câncer de mama entre as mulheres expostas a este 
episódio, foi maior entre as que tinham na época do bombardeio entre 10 e 19 anos, se analisado em relação às mulheres que na época tinham mais que 35 anos. Portanto, enunciou que as radiações ionizantes são indutoras de carcinoma de mama e que, quanto mais jovem na fase de exposição, maior é a ocorrência de carcinoma. Além disso, pôde verificar também uma relação direta com a dose de exposição. Então, as radiações ionizantes podem causar o carcinoma de mama, e se comportam de forma a ser a idade e a dose de exposição importantes na sua causalidade.

Em 1977, Bailar publicou um trabalho em que restringia o uso da mamografia em "screnning" para mulheres com idade inferior a 50 anos. Todavia, o seu trabalho calcou-se em dose por exame de 0,002 Gray, e com a evolução da técnica de mamografia chegou-se atualmente à dose de 0,001 Gray por exame, no centro da mama.

Estes aspectos culminaram com trabalhos que concluíram a favor da mamografia em uma escala muito favorável, numa relação risco/benefício extremamente positiva para a saúde da mulher, a ponto de atualmente ser considerado desprezível o risco de indução de câncer de mama, quando usado sob o rigor da técnica e normas vigentes. O seguinte cálculo nos fala a favor deste problema: se fizermos o exame duas vezes ao ano, em 1.000.000 de mulheres, estaremos dando 7.000 diagnósticos de câncer de mama em fase inicial e estaremos induzindo 6 casos de câncer de mama. Este enunciado é calculado em doses praticadas atualmente, e com um maior critério de avaliação dos mamogramas. HAAGENSEN.(1987)).

Nos últimos anos tem-se tentado identificar alterações mamográficas derivadas de alterações histológicas da mama, mais precisamente nas alterações dtas pré-cancerosas, ou pré-malignas. Esta linha de pesquisa promete uma contemplação da mamografia em um estágio anterior à fase de câncer instalado. Ou seja, antes do câncer inicial. Algumas lesões histológicas estão profundamente comprometidas com o câncer de mama. As formas proliferativas da doença displásica, configurada por hiperplasia ductal, epiteliose e papilomas múltiplos representam, para alguns, a forma inicial do câncer de mama. Destaque deve ser dado à lesão dita doença fibrocística na forma proliferativa, que alguns acreditam ser a histologia inicial do câncer de mama.(BLAND.et al.(1994)). 


\section{2-Histórico do Emprego da Mamografia}

Salomon em 1913 conseguiu, através de radiografias de produtos de mastectomias, caracterizar a forma esquirrosa do câncer de mama em relação a outras formas nodulares. Descreveu as microcalcificações, mas não as associou ao câncer de mama. (BLAND et al. (1994)).

Em 1932 Vogel, descreveu alguns tipos de câncer através da radiografia da mama. Em Buenos Aires, Baraldi em 1933 injetou dióxido de carbono no espaço retromamário, como meio de se conseguir melhor imagem, as custas de uma melhor exposição da mama aos feixes de raios-X. Na Filadélfia, Jacob Gershon Cohen estudou padrões dos cânceres de mama, numa casuística colhida entre os anos de 1937 a 1948, fez grandes avanços na interpretação das radiografias de mama, e em 1948, defendeu a idéia da mamografia ser capaz de identificar o carcinoma oculto. Não conseguiu abarcar mais conhecimentos por uso de técnica equivocada.

Em 1943 e 1949 Raul Leborgne, radiologista de Montevideo, publicou em espanhol suas experiências com a radiografia de mama. Em 1951, publicou em inglês no Journal of Roetgenology and Radiation Therapy suas experiências com o uso dos Raios-X na mama, usando pela primeira vez o termo mamografia, o que foi assimilado nos EUA e incorporado, como procedimento para se diagnosticar o câncer de mama.

Em 1962 alguns trabalhos elaborados no Anderson Hospital no Texas, por R.L. Egan, ganharam grande destaque, pois conseguiu diferenciar o carcinoma dos tumores benignos sem ajuda clínica. Nesta época prevalecia o temor de se induzir câncer de mama com o uso dos Raios-X. Por outro lado, a tecnologia respondeu com o uso de doses de radiação menores e xerografia. Estes trabalhos deram um incremento na especificidade do método em 90\%, levando à possibilidade de se identificar o carcinoma impalpável da mama. (HAAGENSEN.(1987)).

Em 1978 o Instituto Nacional de Saúde e Instituto Nacional do Câncer ros EUA publicaram um consenso, em que diferenciava as duas formas de uso da mamografia: a do "screnning" e a de caracterização do tumor palpável. Neste documento fica clara a vantagem em se usar nos casos palpáveis e fica claro também 
o uso restritivo no "screnning". Conclui-se, junto com outros trabalhos, a relação de tomadas de mamografias e idade para se fazer "screnning": 50 anos. (BLAND et al.(1994) HAAGENSEN.(1987))

\section{3-Análise Médica da Mamografia}

A mamografia tem uma especificidade de $90 \%$, e o risco de falso positivo e de falso negativo existe mesmo quando analisada por médicos experientes. Vale salientar que as mamografias falsas negativas terão como conseqüência um atraso no tratamento da doença e os diagnósticos falsos positivos terão como conseqüência biopsias desnecessárias. Por se tratar de um procedimento invasívo a biopsia expõe a paciente à cicatrizes e riscos cirúrgicos desnecessários, e até formação de doenças benignas da mama, tal como fístula mamária ou mastites sépticas e esteatonecrose, que poderá no futuro dificultar o diagnóstico do câncer de mama. Sabe se que a mama densa é sede da maior porcentagem de falsos negativos. (HAAGENSEN.(1987); BLAND et al.(1994));

Vários critérios norteiam a análise técnica das mamografias, mas a observância de sinais é uma disciplina técnica bastante eficiente. Para isto academicamente classificam-se os sinais mamográficos do câncer de mama, em sinais primários e sinais secundários. (BLAND et al.(1994)); $\mathrm{Na}$ tabela 3.3.1 agrupamos e classificamos os sinais mamográficos. 
Tabela 3.3-1 Agrupa os sinais mamográficos do câncer de mama, em sinais primários e secundá rios.

\begin{tabular}{|c|c|}
\hline SINAIS PRIMÁRIOS & SINAIS SECUNDARIOS \\
\hline 1) Área de densidade aumentada & 1) Espessamento de pele \\
\hline 2) Microcalcificação & 2) Permeação Linfática \\
\hline 3) Distorção Arquitetural & 3) Vascularidade aumentada \\
\hline Tecidual & 4) Comprometimento linfonodal \\
\hline & 5) Dilatação Ductal. \\
\hline
\end{tabular}

\subsection{1 Área de Densidade Aumentada-}

Para tumores menores que $1 \mathrm{~cm}$, as microcalcificações são mais importantes do que a evidência de área densa.Uma área de densidade aumentada, tem mais valor se for visibilizada em todas as incidências. A localização da área densa é outro aspecto importante, visto que o tecido celular subcutâneo segue na mama sendo superficial e os tumores epiteliais da mama, objeto de nosso estudo, são de origem parenquimatosa, e como observado na figura 3.3-2, tem um sentido radial a partir da aréola e respeita a porção estromal gordurosa que é superficial. Logo, áreas densas em posição superficial na mama portam pouco valor preditivo para câncer de mama. Uma vez identificada a área densa, esta deve ser observada no sentido de se identificar se esta lesão invade ou não os tecidos vizinhos. No caso de câncer, a área densa invade e assume um formato estrelar, que configura uma invasão irregular do tecido circunvizinho. Então uma área densa, maior que $0,5 \mathrm{~cm}$, de contorno irregular, fora da periferia da mama, e presente em todos as incidências, é fortemente sugestiva de processo maligno.

Uma outra face que norteia quem esta avaliando um mamograma é o estudo da frequência de carcinomas na mama, segundo a topografia mamaria. Segundo (GONZALEZ et al.(1986)) , por trabalhos publicados por Busk \& Clemmensen (1947), há um predomínio da mama esquerda em 11\%, na incidência de carcinomas. Evidentemente a análise de qualquer sinal mamográfico deve ser feito com todo o rigor, quer esteja nesta ou naquela mama, assim como neste ou naquele quadrante. Por outro lado, existem estatísticas que elegem quadrantes, em que o carcinoma é 
mais comum, mais que isto, quadrantes em que tanto a sintomatologia pré-menstrual, como as lesões benignas são mais freqüentes. Segundo (HAAGENSEN (1987)), os quadrantes superiores são mais bem dotados de parênquima mamário, por uma contingência morfológica. Porém não existem trabalhos que façam uma relação de percentagem de carcinomas com quantidade de tecido mamário, enfim algo quantitativo que sustente a idéia de que o carcinoma assim, como as lesões benignas, são mais comum nos quadrantes superiores, por ter mais tecido mamário, numa avaliação percentual.

Por outro lado, o estudo estatístico de freqüência de adenose tumoral, e carcinoma segundo a topografia mamaria, exibe números muito distantes. Como pode se observar na Figura 3.3-1.

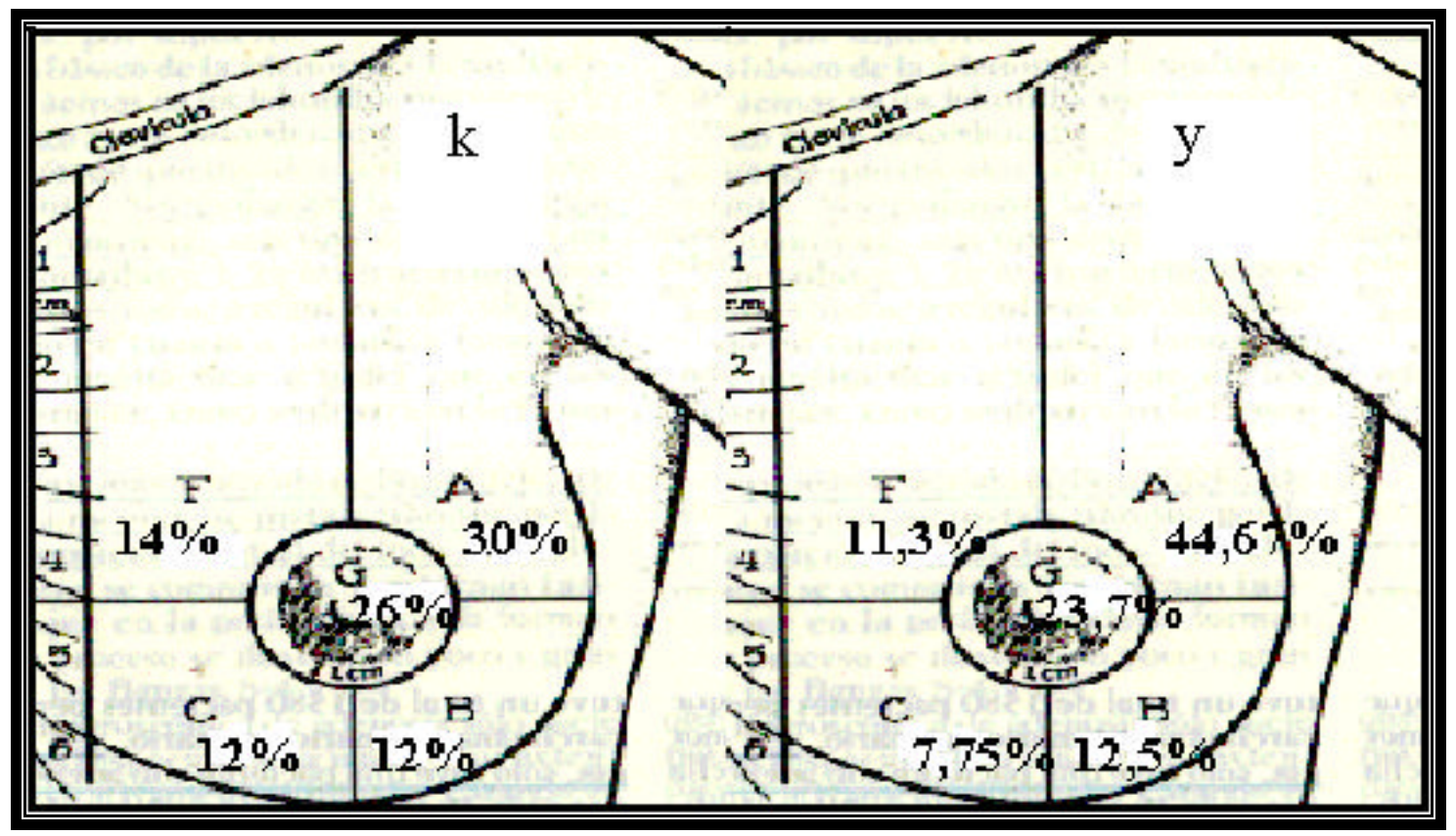

Figura 3.3-1 Demonstra a frequiência de: (k) adenose tumoral, HAAGENSEN (1987); (Y) carcinoma, GONZALEZ et al.(1986). Segundo a topografia mamaria.

Evidentemente que uma área de densidade aumentada nos quadrantes superiores tem maior probabilidade de ser câncer, ou mesmo de ser doença benigna. A análise da Figura 33-2, que se refere a dois cortes do tórax, envolvendo a mama, em duas tomadas que coincidem com as tomadas das duas incidências mais comuns 
em mamografia, (médio-lateral e crânio-caudal), permite uma visualização do posicionamento do tumor na anatomia mamária, a partir da mamografia.Vale salientar, que apesar da frequiência dos carcinomas ter uma variação bem estabelecida pela figura 3.3-1, o prognostico dos carcinomas na mama, variam também pela localização. Então uma área densa de localização no quadrante súpero externo tem um significado diferente em relação a uma área densa de mesmo tamanho e formato de localização em outro quadrante, na avaliação clínica.E isto, também é importante para o médico que esta avaliando uma mamografia, pois redundará ou não em uma intervenção cirúrgica. Assim, estatisticamente, os carcinomas localizados nos quadrantes externos têm um melhor prognóstico, em relação aos quadrantes internos. Mas o quadrante central oferece o pior prognóstico. (GONZALEZ et al (1986)).

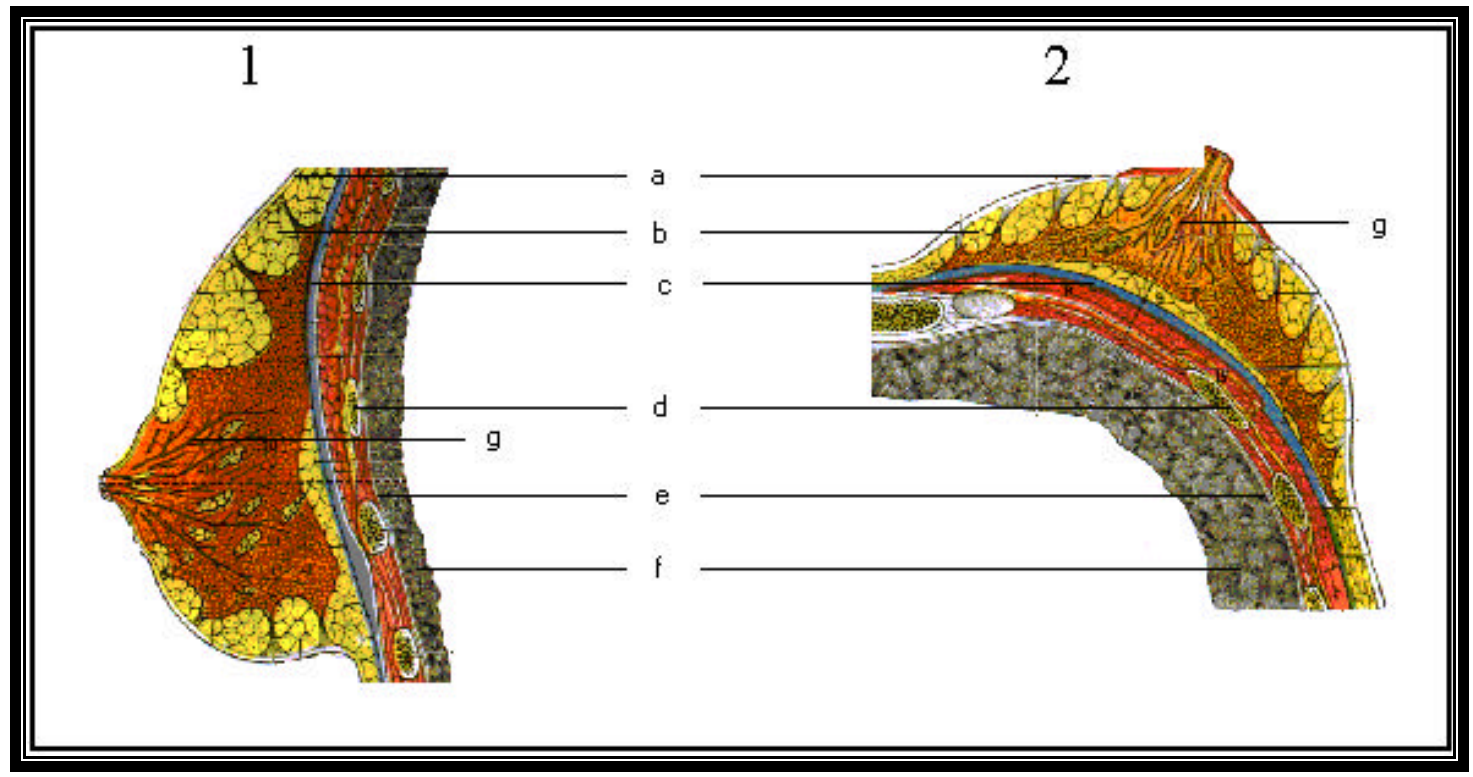

Figura 3.3-2- Demonstra dois cortes do tórax envolvendo a mama. Sendo (1) Corte Vertical e (2) Corte Horizontal. Estão representadas as seguintes estruturas: a) Pele da Mama; b) Gordura Pré-Glandular; c) Espaço Retromamario; d) Costela ; e) Pleura ; f) Pulmão ; g) Ductos Lactíferos. Fonte- TESTUT

Tumores mais dotados de receptores hormonais possuem contornos mais irregulares, por crescerem mais. Por outro lado, tumores benignos são encapsulados, e de contornos regulares. Estas particularidades dos tumores podem ser 
caracterizadas nos mamogramas Todavia, pode-se deparar com tumores malignos de contornos regulares, ou pouco irregulares, que são mais ou menos dotados de receptores hormonais.

Hematomas, cistos, cicatrizes, abscessos e linfonôdos podem ter uma aparência de área densa, porém os linfonôdos são os que oferecem maior dificuldade em se discernir.

\subsubsection{Microcalcificações-}

As microcalcificações foram primariamente identificadas pelos patologistas e somente recentemente associadas aos achados mamográficos, embora já tivessem sido relatadas por Salomon em 1913..

As deposições de cálcio em tecidos lesados são classificadas em três grupos: a) Calcificação distrófica; b) Calcificação metastática; c) Calcificação idiopática. A primeira é a que mais interessa, pois está diretamente relacionada com os fenômenos averiguados nas microcalcificações encontradas na mama. O cálcio que se envolve nesta calcificação na realidade é de origem tanto extracelular como intra celular e do plasma. O termo distrofia conota aqui um distúrbio de suprimento de elementos do trofísmo do tecido. Na realidade é um processo que se assemelha ao processo fisiológico de ossificação. (MONTENEGRO et al.(1992))

O tumor tem uma necessidade metabólica aumentada, pois está em crescimento constante, que depende de um suprimento vascular adequado, pois é através dele que o tumor obtém nutrientes e consegue excretar metabólitos. O suprimento vascular na maioria das vezes acompanha o aumento do tumor, mas o sistema pode desacoplar e aí surgem áreas isquêmicas de forma pontuais, que com a persistência ou intensidade, estas áreas transformam-se em áreas necróticas. Mas antes de necrosar e haver morte celular existe a lesão celular, e o mecanismo começa com a mudança do Ph e subseqüente seqüestro de cálcio para o local da lesão celular. Então o mecanismo envolvido com a formação de microcalcificação no caso de distrofias, como é o caso das microcalcificações encontradas em tumores, é o isquêmico. $\mathrm{Na}$ realidade, as microcalcificações se instalam em áreas enfartadas, em que o suprimento sanguíneo foi tão insuficiente que causou uma necrose coagulativa, e aí desencadeou o processo de precipitação de cálcio, que culmina com a formação 
de microcalcificação. Mas nos tumores, o processo se desacopla por um aumento de demanda, ao contrário do que acontece na maioria dos processos isquêmicos do organismo, em que uma determinada vasculopatia restringe o suprimento sanguíneo. No caso dos tumores, em que existe uma perda de relação entre o suprimento e a necessidade do tumor, o que existe é um aumento de demanda, que não foi acompanhado pelas colaterais vasculares, ou se houve colaterais, não de forma farta. Fato é que surgem pontos no tumor em que o suprimento não é satisfatório.( BOGLIOLO.( 1972); MONTENEGRO et al (1992)).

Assim as microcalcificações verificadas na mama são decorrentes de necroses pontuais que ocorrem no tumor, na vigência de isquemia. Então quando se dá a lesão celular o meio passa a ser ácido e estes grupos ácidos conjugam os fosfatos que servem de núcleo para o depósito do cálcio.( MONTENEGRO et al (1992)).

A presença de microcalcificações na mama é prova irrefutável de patologia mamaria, de forma alguma fazem parte da histologia e jamais serão vistas sem que estejam associadas a uma patologia.(BLAND.et al.(1994)). Quanto à presença, podese ainda acrescentar que em 50\% da presença de microcalcificações pode ser encontrado o carcinoma. Pode-se ainda dizer que, 30-40\% dos cânceres iniciais se manifestam única e exclusivamente por algumas microcalcificações. Nos cânceres ocultos, em $75 \%$ dos casos, notam-se microcalcificações. Em 10-20\% das microcalcificações não estão associadas à área de densidade aumentada, ou seja, não se percebe halo tumoral (BLAND.et al.(1994); HAAGENSEN.(1987)).

As microcalcificações de secreção intraductal tendem a ser lineares e de orientação em fuso, tal como os ductos, e de ocorrência bilateral. Na adenose esclerosante, tende a ocorrer de forma bilateral também, mas o formato é de difícil discernimento com o carcinoma. Na epiteliose ductal a ocorrência é geralmente em fileiras de microcalcificações desenhando os ductos. No fibroadenoma as microcalcificações tem o aspecto de pipoca. A lactocele tem calcificações pequenas com contornos incompletos. As microcalcificações vasculares ocorrem de forma bilateral e em fileiras, em pacientes mais idosas e desenhando um trajeto aleatório. (BLAND. et al.(1994); PIATO.(1979)). 


\subsubsection{Distorção da Arquitetura-}

O valor preditivo deste sinal é inferior ao da área densa e microcalcificação. Contudo, alguns autores a incluem como sinal primário do câncer de mama. Aliás, de forma acertada, afinal é uma manifestação primária da presença de neoplasia na área em evidência. Este aspecto é oriundo da capacidade de registro que a mamografia tem em revelar estruturas estudadas na histologia da mama, tal como ligamentos e ductos. A análise se faz em comparação com a mesma área da outra mama, que tende a ser idêntica.( BLAND. et al.(1994)).

\subsubsection{Edema de Pele ou Espessamento de Pele-.}

O edema de pele é um sinal que pode estar presente no carcinoma de mama, quando este dificulta a drenagem linfática da mama, que pode ser por embolização dos vasos linfáticos ou até mesmo já grande comprometimento dos linfonôdos. Mas esta presente em doenças inflamatórias, insuficiência cardíaca, edemas posturais, doença de Mondor, nefropatias, traumas e outras eventualidades patológicas. Para pacientes que ficam a maior parte do tempo ereta este surge na porção inferior da mama, para as pacientes acamadas surgem na região periareolar. Citado em laudo como sendo espessamento de pele, mas visto pelo mastologista na presença da paciente, como edema de pele, que ele pode confirmar pelo aspecto que a pele assume em casca de laranja.

\subsubsection{Permeação Linfática-}

A permeação linfática é o fato da drenagem linfática estar debilitada e isto causa o aspecto típico de edema de pele.

\subsubsection{Aumento da Vascularidade-}

O aumento da vascularidade é um dado que só tem valor se for extraído da comparação entre as duas mamas, podendo ser um sinal desprovido de significado quando em uma mama somente. 


\subsubsection{Dilatação Ductal-}

Comum da fase pós-menopausa, mas carece de significado se bilateral, se unilateral deve de ser investigado, pois associa-se ao carcinoma de mama.

\subsubsection{Linfonôdos Comprometidos-}

Os linfonôdos intra-mamários são comuns e são menores que os linfonôdos da cadeia axilar. Geralmente tem por volta de $1,5 \mathrm{~cm}$ e contem um seio marginal transparente, os linfonôdos intra-mamários tendem a ser menores e de aparência habitual. Os linfonôdos enfartados tendem a ser maiores e arredondados, sem transparência marginal.(BLAND. et al.(1994))

\section{4-Aspectos Físicos da Mamografia}

A mamografia constitui uma forma particular de radiografia que utiliza níveis de tensões mais baixos que os utilizados em radiografia convencional e se destina a registrar imagens das mamas a fim de diagnosticar a eventual presença de estruturas indicativas de doenças, sobretudo de câncer. De acordo com Vieira VIEIRA,(2002), a mamografia de alta resolução oferece uma sensibilidade média (possibilidade de visualização de estruturas de interesse) de $91 \%$ a $96 \%$, variando essas taxas em função da idade, do tipo de mama e do tamanho da lesão. Além disso, apresenta uma taxa de falsos-negativos (tumores que não são detectados) em torno de $4 \%$ a $9 \%$.

Antigamente, as imagens mamográficas eram obtidas por meio de equipamentos radiográficos convencionais. Com o passar do tempo, acessórios foram acrescentados para que esses aparelhos se tornassem mais adequados para registrar a imagem da mama, até surgirem os equipamentos dedicados exclusivamente para a mama, chamados de mamógrafos. Nos últimos anos, todo o sistema de mamografia sofreu um grande avanço, visando melhorar a detecção precoce do câncer de mama. Atualmente, todo o processo de aquisição da mamográfia é dedicado exclusivamente a esse tipo de exame: equipamento, sistema de registro, técnica radiográfica, reveladora, negatoscópio, etc. 
Os mamógrafos diferem dos equipamentos convencionais devido às particularidades radiográficas dos tecidos que compõem a mama, basicamente tecido glandular, tecido fibroso e gordura (Figura 3.3-1). Esses tecidos possuem níveis de atenuação aos Raios-X muito próximos, o que acarreta um baixo contraste na imagem. Além disso, as estruturas indicativas de câncer, como as microcalcificações e pequenos nódulos, devem ser visibilizadas ainda em seu estado inicial e, portanto, possuem dimensões reduzidas (entre 0,1 e $0,5 \mathrm{~mm}$ de diâmetro). Assim, os equipamentos mamográficos devem não só gerar imagens de alto contraste como também com alta resolução espacial e baixo ruído.

Para se conseguir um contraste adequado nas imagens de mama, os mamógrafos operam numa faixa mais baixa de energia, comparada aos equipamentos convencionais, com valores usuais entre 22 e $35 \mathrm{keV}$. Para fótons de baixa energia, as diferenças entre os coeficientes de atenuação dos tecidos que compõem a mama são maiores, o que resulta em diferentes níveis de enegrecimento no filme radiográfico. A Figura 3.4-1 mostra um exemplo de como o contraste entre a imagem de um tumor e de uma pequena calcificação decresce com o aumento da energia dos fótons.

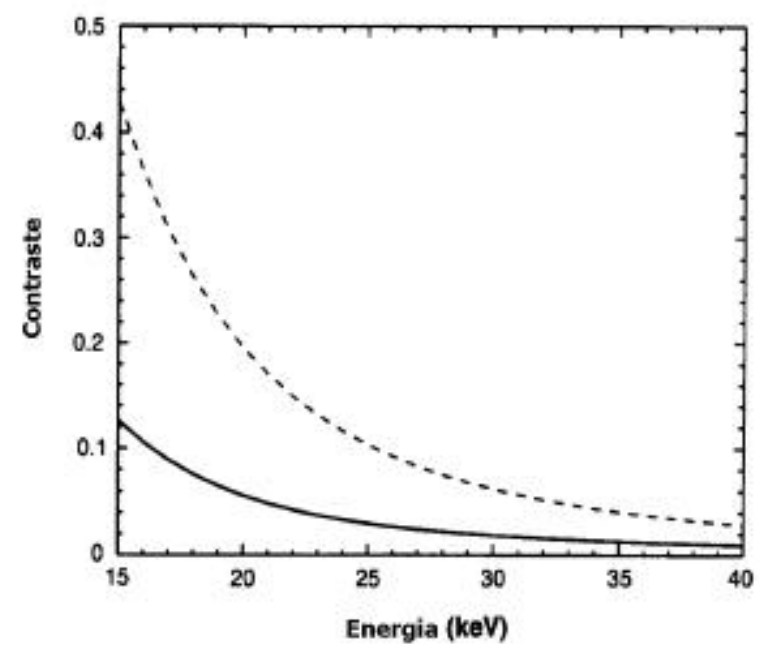

Figura 3.4.1. Contraste entre um tumor de $5 \mathrm{~mm}$ de diâmetro (linha cheia) e uma pequena calcificação (linha tracejada) em função da energia da radiação HAUS et al_(2000).

O espectro de radiação gerado pelo tubo mamográfico também exerce influência bastante significativa no contraste da imagem. De modo geral, os aparelhos de mamografia possuem tubo com alvo de molibdênio (Mo) no lugar do 
tungstênio (W), e em alguns aparelhos mais modernos ainda podem ser encontrados alvo de ródio $(\mathrm{Rh})$. A vantagem da utilização desses elementos no alvo é que eles garantem uma grande emissão de radiação característica de baixa energia (17,4 e 19,8 keV para o molibdênio), permitindo a formação de um espectro mais adequado para produzir imagens mamográficas de alto contraste. A Figura 3.4-2 ilustra um exemplo de espectros de Raios-X produzidos com alvo de molibdênio e ródio.

Quando um filtro de molibdênio, tipicamente de $0,03 \mathrm{~mm}$, é utilizado na produção do feixe, o espectro ainda perde os fótons de muito baixa energia, que geralmente não contribuem para a formação da imagem, pois são quase totalmente absorvidos pela mama, mas aumentam a dose na paciente. Além disso, fótons de energia maior que $20 \mathrm{keV}$ também sofrem grande filtração devido à alta absorção pela camada $\mathrm{k}$ do molibdênio nessa faixa de energia. Isso acaba resultando em um espectro quase totalmente formado por radiação característica ou de energia muito próxima a ela, permitindo a formação de imagem de alto contraste e ainda diminuindo a dose absorvida pela mama durante o exame HAUS et al _(2000).

Para mamas maiores ou mais densas, em que há uma maior quantidade de tecido fibroglandular presente, o contraste na imagem não é tão alto como o obtido com uma mama normal. Isto ocorre porque poucos fótons de baixa energia conseguem atravessar a mama para atingir o filme, o que provoca um "endurecimento" do feixe (aumento da energia efetiva) e, conseqüentemente, uma diminuição na diferença de absorção (e contraste) entre os tecidos presentes na mama. Embora um aumento de energia possa ser conseguido com um aumento da tensão do tubo $(\mathrm{kVp})$, a eficiência do espectro continua sendo limitada pela radiação característica que possui valor fixo. Assim, nos exames mamográficos, utilizam-se diferentes combinações de alvo e filtro, com diferentes materiais, para definir o formato do espectro de emissão e conseguir o melhor contraste possível na mamografia. Por exemplo, utilizando-se alvo de molibdênio com um filtro de ródio $(\mathrm{Mo} / \mathrm{Rh})$, consegue-se um feixe mais energético e penetrante do que com o filtro de molibdênio (Mo/Mo) para a mesma $\mathrm{kVp}$, adequado para exames de mama mais densas ou de maior volume. Isso ocorre pois a camada $\mathrm{k}$ do ródio possui energia de $23 \mathrm{keV}$, permitindo que os fótons entre 20 e $23 \mathrm{keV}$ não sejam absorvidos, como no caso da filtração com molibdênio (Figura 3.4-2). 


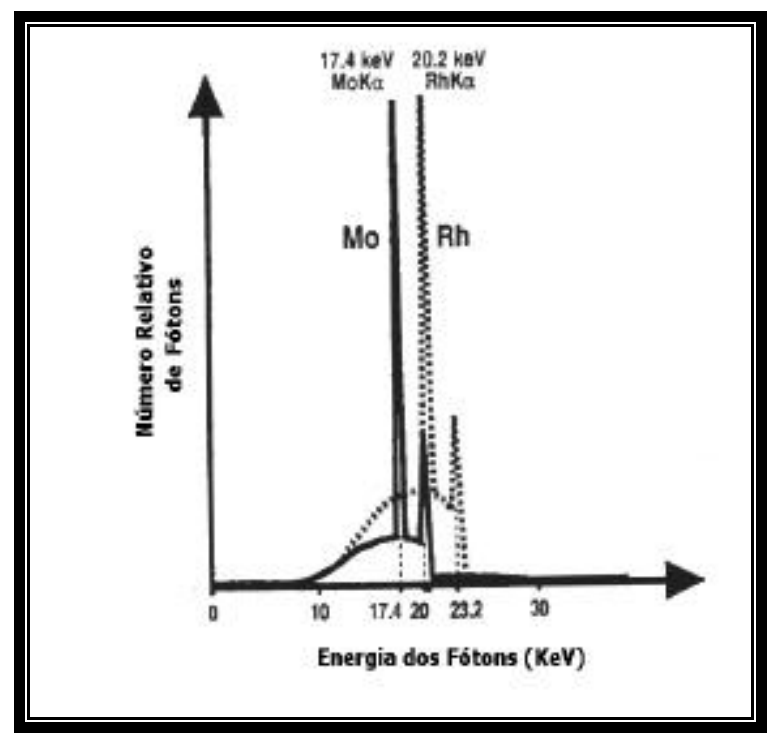

Figura 3.4-2. Espectro de emissão típico de um equipamento mamográfico. Para o alvo de molibdênio (Mo) foi utilizado um filtro de $0,03 \mathrm{~mm}$ de molibdênio e $26 \mathrm{kVp}$ de tensão. Para melhor penetração do feixe, um filtro de ródio (Rh) deve ser utilizado (linha tracejada), HAUS et al_(2000)

Além dos dispositivos comuns aos aparelhos convencionais de radiografia, o mamógrafo possui um compartimento de compressão, composto por duas placas de plástico, cuja finalidade é comprimir a mama de modo a homogeneizar ao máximo a densidade a ser radiografada. Na Figura 4.4-3 é apresentada uma fotografia de um aparelho mamográfico real, em que se destaca o compartimento de compressão. 


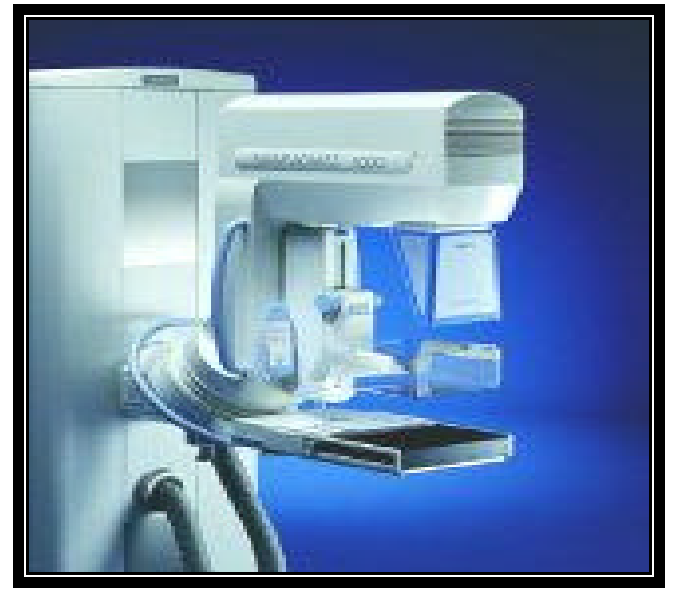

Figura 3.4.3. Imagem de um aparelho mamográfico comercia1

A compressão da mama, apesar de provocar um desconforto para a paciente durante o exame, melhora significativamente a qualidade da imagem mamográfica. As mamas comprimidas, possuindo uma espessura menor e mais uniforme, favorece a diminuição da dose absorvida, diminui o espalhamento dos fótons de Raios- $\mathrm{X}$ no filme e conseqüentemente o ruído na imagem, reduz a sobreposição de imagens das estruturas internas da mama e garante a imobilidade da paciente durante o exame. Além disso, os aparelhos mamográficos mais novos possuem também uma grade móvel, colocada entre a mama e o cassete radiográfico, para reduzir a radiação espalhada e conseqüentemente o ruído das imagens mamográficas.

Para garantir imagens de alta resolução espacial, os equipamentos mamográficos devem possuir ponto focal com dimensões bem menores do que os encontrados em aparelhos convencionais. De modo geral, os equipamentos convencionais apresentam ponto focal aparente em torno de $1,0 \mathrm{~mm}$ ou mais de diâmetro enquanto os mamógrafos apresentam valores em torno de $0,3 \mathrm{~mm}$. Considerando que a distância entre a mama comprimida e o cassete mamográfico é muito menor do que a distância do foco ao filme, consegue-se uma magnificação geométrica bastante razoável para se obter alta resolução espacial na imagem. Geralmente a distância entre a mama e o filme não ultrapassa $2 \mathrm{~cm}$, enquanto a distância total entre o filme e o ponto focal fica em torno de $65 \mathrm{~cm}$. 


\section{Capítulo 4 - Processamento de Imagem em Mamografia}

\section{1-Digitalização de Imagem Mamográfica}

O processo de aquisição da imagem mamográfica digital é uma das mais importantes etapas do processo de diagnóstico auxiliado por computador (CAD). É nesta etapa que são definidos alguns parâmetros de qualidade da imagem digital, como resolução e contraste, que serão de fundamental importância para o desempenho do diagnóstico computacional e também do diagnóstico médico CHAN_(1994).

Devido ao alto custo dos mamógrafos digitais e também por serem equipamentos muito recentes, em alguns casos ainda em fase de desenvolvimento, a grande maioria das imagens mamográficas digitais existentes atualmente são, na verdade, imagens digitalizadas, obtidas a partir do mamograma original em filme. A obtenção dessas imagens geralmente é feita através do uso de "scanners" especiais para filme radiográfico, que compreendem basicamente dois elementos: o sensor e o conversor analógico-digital (A/D).

O sensor é um dispositivo físico sensível a uma faixa de energia no espectro eletromagnético (como Raios-X, luz visível ou laser), que produz na saída um sinal elétrico proporcional à intensidade detectada. $\mathrm{O}$ conversor $\mathrm{A} / \mathrm{D}$ é um dispositivo que transforma o sinal elétrico (analógico) gerado pelo sensoriamento físico em um sinal digital. Entre os dispositivos sensores mais freqüentes utilizados na aquisição de imagens digitais estão os microdensitômetros, os tubos fotomultiplicadores (PMT) e os CCDs GONZALEZ_(1992).

O microdensitômetro consiste num equipamento capaz de promover uma varredura no filme radiográfico que se movimenta fixado por um rolo ou tambor. A 
varredura é obtida ao se focalizar um feixe de luz ou laser na imagem e ao mesmo tempo girar o tambor em relação ao feixe para movimentar o filme. No caso de radiografias, o feixe passa através do filme e é focalizado num fotodetector onde o nível de cinza em cada ponto da imagem é registrado pelo detector com base na intensidade do feixe transmitido (densidade óptica). Uma imagem digital é obtida ao se permitir apenas valores discretos de intensidade e posição, sem a utilização de um conversor A/D. Embora os microdensitômetros sejam dispositivos lentos, eles são capazes de desejável ao processamento computacional. Esse processo de discretização espacial é chamado de amostragem e o processo de discretização de amplitude é chamado de quantização MARQUES FILHO_(1999).

Basicamente, a amostragem converte uma imagem analógica contínua $\mathrm{f}(\mathrm{x}, \mathrm{y})$ em uma matriz discreta, igualmente espaçadas, de $\mathrm{M}$ por $\mathrm{N}$ pontos. Cada ponto corresponde a um elemento da imagem digital e é chamada de "pixel" (do alto nível de precisão no posicionamento, devido à natureza essencialmente contínua da translação mecânica usada no processo de digitalização. São muito utilizados nos procedimentos de determinação experimental das funções de transferência.

Um tubo fotomultiplicador (PMT) consiste da combinação de um fotodiodo a vácuo e um multiplicador de elétrons colocados dentro do mesmo tubo. O fotodiodo capta os fótons incidentes através de um fotocatodo que promove a geração de elétrons através do efeito fotoelétrico. Os elétrons são então acelerados para o anodo positivamente carregado gerando uma corrente elétrica. O multiplicador de elétrons amplifica o fluxo inicial desta corrente por meio de múltiplas emissões secundárias de elétrons. Esse processo produz correntes com uma magnitude bem maior que a corrente inicialmente obtida pela fotoemissão BURKE_(1996). Os "scanners" que utilizam os PMTs para a aquisição de imagens são mais sensíveis ao ultra violeta e à luz visível e também possuem algum tipo de mecanismo para movimentarem o filme durante a varredura.

O conversor A/D é um dispositivo para a conversão da saída elétrica (sinal analógico) de um dispositivo de sensoriamento físico para a forma digital, de forma que esta informação possa ser representada através de bits 0s e 1s e assim interpretada pelo computador. O sinal analógico obtido na saída do dispositivo de aquisição deve, então, ser submetido a uma discretização em espaço e amplitude, 
para tomar o formato inglês "picture element"). Quanto maior o número de valores de $\mathrm{M}$ e $\mathrm{N}$ utilizados na digitalização de uma imagem, maior será sua resolução espacial e conseqüentemente melhor será sua qualidade quando comparada à imagem original. Além da forma M x N (linhas por colunas da imagem), a resolução espacial de uma imagem digital pode ser apresentada na forma de quantidade de pontos por polegada ou DPI (do inglês "dot per inch") ou também pelo tamanho do "pixel"

A quantização faz com que cada um destes "pixels" assumam um valor inteiro, na faixa entre 0 e $2^{n}-1$ valores, sendo $n$ o número de bits do conversor A/D. Quanto maior o valor de $n$, maior o número de níveis de cinza presentes na imagem digitalizada e melhor será sua qualidade. Do ponto de vista eletrônico, a digitalização consiste em uma conversão analógico/digital na qual o número de amostras do sinal contínuo, por unidade de tempo, indica a taxa de amostragem e o número de bits do conversor A/D utilizado determina o número de tons de cinza resultantes na imagem digitalizada.

$\mathrm{Na}$ especificação do processo de digitalização, deve-se decidir quais valores de $\mathrm{N}, \mathrm{M}$ e $n$ são necessários para a produção de uma imagem digital de qualidade adequada. Do ponto de vista qualitativo, é certo que quanto maiores os valores de $\mathrm{M}$, $\mathrm{N}$ e $n$, melhor será a qualidade da imagem digitalizada. No entanto, maiores serão os "custos" computacionais envolvidos, como tempo de digitalização e processamento, e memória para o armazenamento. Portanto, para se definir tais valores devem-se levar em conta os fins para os quais a imagem está sendo digitalizada. No caso da mamografia, vários trabalhos visam definir a quantidade mínima de resolução (espacial e contraste) para um processamento confiável visando ao diagnóstico computacional.

No caso de digitalização de imagens mamográficas, a qualidade da imagem digitalizada está diretamente associada à taxa de detecção de pequenas estruturas no diagnóstico computadorizado, como, por exemplo, as microcalcificações. A resolução a ser empregada na digitalização dos mamogramas deve estar relacionada diretamente com as características do filme mamográfico e das estruturas pesquisadas CHAN_(1994).

O filme mamográfico possui grãos de aproximadamente $0,0015 \mathrm{~mm}$ a 0,003mm de diâmetro CURRYIII_(1990) e as microcalcificações possuem tamanho 
em torno de $0,1 \mathrm{~mm}$ a $0,5 \mathrm{~mm}$ de diâmetro. Dessa forma a resolução espacial empregada no processo de digitalização fica limitada a um tamanho de "pixel" entre 0,1 mm (limitado pelo tamanho da microcalcificação) e 0,015 mm (limitado pelo tamanho de aproximadamente 5 maiores grãos do filme). O tamanho mínimo de 5 grãos é aconselhável para que se evite a incorporação de sinais de ruído ao "pixel" RUSS_(1992).

\section{2-Processamento de Imagem Mamográfica}

A identificação segura de estruturas suspeitas nas mamografias é de grande relevância devido à possibilidade de evitar procedimentos cirúrgicos invasivos, biópsias desnecessárias e até mesmo a morte da paciente. Entretanto, a dificuldade para identificar certas estruturas nos mamogramas, como por exemplo, as microcalcificações, ocorrem porque elas geralmente tendem a se confundir com outras estruturas de semelhante contraste na faixa de energias empregadas pelo mamógrafo. Isso é tanto mais problemático quando se trata de imagem de uma mama densa, cuja constituição tende a apresentar menos tecidos gordurosos, o que faz com que haja maior absorção de Raios-X e, portanto, menor diferenciação de contraste no filme. Os radiologistas fazem normalmente uma busca na imagem com lupas para garantir um nível maior de eficiência, mas, devido à sutileza da imagem, há sempre um razoável potencial de engano ou "perda" dessa informação no exame.

A utilização do computador no processamento de mamogramas para o reconhecimento de anormalidades teve seu início com Winsberg et al. WINSBERG et al_(1967) que descreveram um procedimento para analisar as densidades ópticas da imagem e, a partir daí, relacionar diferenças bruscas com áreas suspeitas. No entanto, até o final da década de 80, a maioria desses estudos cujo objetivo era quantificar aspectos mamográficos para discriminar tumores benignos e malignos apresentava precisão inferior à de observadores humanos experientes CHAN_(1998). Contudo, o desenvolvimento de sofisticados sistemas radiográficos digitais criou um interesse renovado em esquemas de diagnóstico auxiliado por computador em radiologia. Associado a isso, os procedimentos de processamento de imagens 
digitalizadas ganharam força ao longo da década de 90, constituindo-se num importante recurso para auxiliar o radiologista DAVIES_(1990). Entre as técnicas empregadas, particular interesse remete às que buscam detectar e/ou classificar as microcalcificações (QIAN_95, JIANG_98), nódulos e tumores LAI_(1989), BRZAKOVIC (1990), além das técnicas de pré-processamento que visam aprimorar o contraste nas imagens mamográficas para melhorar a detecção das estruturas de interesse RAM_(1982,); J.I (1994).

Para realização do processamento computadorizado da imagem mamográfica, visando a detecção automatizada de estruturas de interesse, os procedimentos básicos geralmente partem da digitalização dos mamogramas originais para utilização subseqüiente de técnicas de processamento sobre a imagem digital. Apenas no caso dos mamógrafos digitais o procedimento de digitalização do mamograma é dispensado, devido à aquisição direta da magem digital pelos detectores do equipamento HAUS et al_(2000).

Além dos fatores inerentes ao aparelho namográfico, alguns aspectos podem dificultar a percepção desses sinais durante a inspeção visual do mamograma, assim como criar barreiras para o processamento computadorizado quando se pretende identificar e classificar as lesões mamárias. Alguns deles relacionam-se às características do mamograma, outros são resultantes de limitações da digitalização e outros ainda constituem características intrínsecas da própria lesão. Os detalhes e características dos mamogramas devem ser previstos de forma que seja possível estabelecer procedimentos automatizados para encontrar as estruturas desejadas (ISHIDA_(1984), DHAWAN_(1988)).

Sickles SICKLES_(1982) apresentou uma série de testes que foram realizados a fim de estudar a detectabilidade de pequenas estruturas em mamografias com sistemas écran-filme. O objetivo principal foi demonstrar que a detectabilidade dessas estruturas nos sistemas testados dependem muito das especificações utilizadas quanto ao filme, ponto focal, posicionamento e outros aspectos, que tornam impossível o estabelecimento de um procedimento global sem interação humana. Neste trabalho, foram avaliadas 24 técnicas radiográficas, usando uma grande variedade de tubos de Raios- $X$, sistemas de registro de imagem e graus de magnificação. Microcalcificações foram simuladas por grãos de óxido de alumínio, 
de tamanho variando entre $0,15 \mathrm{~mm}$ e $0,55 \mathrm{~mm}$, arranjados randomicamente em clusters, sendo alocadas, para cada cluster, de 4 a 12 partículas de cada um dos seis tamanhos definidos para as microcalcificações. As estruturas simuladas foram coladas em tiras de tecidos de mamas humanas de mulheres adultas. O autor chegou às seguintes conclusões: a detectabilidade das partículas foi melhorada nas técnicas de magnificação, quando utilizado o foco fino $(0,1 \mathrm{~mm})$; nenhuma das calcificações simuladas menores que $0,29 \mathrm{~mm}$ foi detectada pelas técnicas convencionais, mas todas as técnicas de magnificação, porém, registraram com sucesso pelo menos alguns dos pontos com tamanho igual ou inferior a $0,22 \mathrm{~mm}$.

Chan et al. (CHAN_1994) avaliaram a influência do tamanho e da intensidade do "pixel" em mamogramas digitalizados na previsão de um esquema automatizado de detecção. Foram digitalizados 25 mamogramas obtidos por um equipamento com ponto focal de $0,3 \mathrm{~mm}$. Cada mamograma possuía um cluster de microcalcificações comprovado por biópsia. Os mamogramas foram digitalizados com tamanho de "pixel" de 0,035 mme 12 bits de resolução de contraste. O sistema de aquisição foi calibrado de tal forma que a densidade fosse linearmente relacionada com valores de "pixel" no intervalo 0,1 a 2,8 unidades de densidade óptica, sendo que cada valor de "pixel" representava 0,001 unidade. Mamogramas digitalizados com tamanho de "pixel" grande ou menor número de bits foram simulados através da média de "pixels" adjacentes ou truncando-se bits menos significativos, respectivamente. $\mathrm{O}$ processamento foi aplicado a imagens de vários tamanhos $\mathrm{e}$ intensidades de "pixel" e para cada tamanho foi testado um conjunto de parâmetros. Os resultados indicaram que o tamanho do "pixel" e a quantidade de níveis de cinza utilizados na digitalização exercem grande influência na detecção de microcalcificações. Além disso, os efeitos dos parâmetros de digitalização na precisão de detecção também dependem muito das imagens utilizadas para teste. Se as imagens possuem microcalcificações, essa dependência é ainda maior.

Assim, os principais requisitos de métodos computacionais para detecção de estruturas de interesse em mamografia é que preservem a forma e o tamanho das estruturas individuais da imagem. Para isso, é necessário que algumas características importantes da imagem digital sejam padronizadas a fim de garantir que eventuais problemas de qualidade possam prejudicar a detecção computadorizada. Os 
pesquisadores da área consideram que níveis de quantização de 10 bits com resolução espacial da ordem de 0,1 mm (tamanho de "pixel") são adequados para uma boa detecção das estruturas mais relevantes no exame mamográfico.

Essas são algumas características necessárias à elaboração dos bancos de imagens para os testes de desenvolvimento e desempenho dos esquemas CAD. É bem reconhecido que as características das imagens armazenadas nessas bases de dados podem afetar significativamente o desempenho de um esquema CAD ou de uma técnica particular de processamento NISHIKAWA_(1994). Todavia, as bases de dados existentes, disponíveis ou não, geralmente não oferecem uma padronização que permita uma comparação confiável entre o desempenho de diferentes técnicas ou diferentes esquemas CAD. 


\section{Capitulo.5 - Variações Biológicas da Mama}

Pelo fato de se ter interesse na variação orgânicas da mama concernente a um ciclo menstrual, suas variações anatômicas e fisiológicas foram incluídas aqui, apenas para que o assunto fosse esgotado.

Vale salientar que temporalmente o ciclo menstrual foi dividido em fases e isto se deu por volta de 1908 , com trabalhos publicados por Hitschmann e Adler. Estes estudaram a variação histológica do útero, vagina e trompa de Falópio , perante um ciclo menstrual. Até os dias atuais, alguns patologistas tem dificuldades em identificar a fase do ciclo menstrual apenas pela análise histológica de espécimes colhidas do útero, tamanha é a variabilidade de amostragem e falta de critério homogêneo de seleção. Novak \& Jones (1977) .O útero esta sob efeitos de vários hormônios, assim como sofre influência de passado de gravidez e de uso de anticoncepcional, assim como da idade da mulher. Com vistas nestes estudos, o ciclo menstrual foi dividido em: fase proliferativa, fase secretora e fase menstrual. Mas outras classificações surgiram, tal como fase folicular e luteal, assim como fase préovulatoria e fase pós-ovulatoria e outras, que incluem a fase hemorrágica etc.

Existem evidências de que a mama também sofre variações suficientemente patentes, para se reconhecer a fase do ciclo apenas pela analise da histologia mamaria. (BLAND et al (1994)). Porém alguns aspectos devem ser abordados antes de se descrever estas variações da mama, ao longo do ciclo. Assim como o útero, a mama também, esta sujeita a um grande número de hormônios e fatores tais como idade, historia obstétrica, história endócrina, uso de anticoncepcional, distúrbios endócrinos tal como obesidade, história familiar etc.(HAAGENSEN ( 1987)). Além destes aspectos, temos ainda a variabilidade citada por vários autores, de região para região da mama (VOGEL et al( 1981)). Uma outra dificuldade em se estabelecer diretrizes de analise destas variações é a forma de coleta do material. Alguns trabalhos foram feitos em material colhido de mamas com patologia maligna e 
outros com patologia benignas assim como material vindo de cadáveres. Outros materiais foram colhidos de mamas que se submeteram à mastectomia subcutânea assim como material de mamoplastia redutora. Por outro lado, alguns se basearam em material colhidos por agulha fina e outros por material colhido por biópsia a céu aberto.

Fato é que a variabilidade dos fatores intrínsecos à paciente, assim como o método que o autor usou são passíveis de distorcer os resultados obtidos.

A análise da maioria do material foi feita em nível de microscópio óptico usando-se coloração por hematoxilina e eosina.( H-E). Esta análise foi desde a arquitetura tecidual, como citológica do parênquima e do estroma, conteúdo de DNA e forma de núcleo e citoplasma das células do parênquima.

\section{1-Variações Anatômicas da Mama}

O formato da mama lembra uma semi esfera, que se relaciona com o tórax por sua face plana, e a sua face convexa tem em seu ápice o mamilo. Podemos diferenciar na mama dois diâmetros, o ântero-posterior e o diâmetro látero-lateral. Quando o diâmetro ântero-posterior se alonga, a mama assume um formato cônico, e se o diâmetro ântero-posterior se encurta temos a mama discoide ou aplainada. Quando o diâmetro látero-lateral encurta temos a mama pediculada. Estas variações são de decorrência genética e de historia de gestação e de amamentação, assim como intercorrências de saúde. O volume da mama tem uma relação direta com a herança e com a fase da mulher. Ao nascimento, a mama tem em média 10mm, na puberdade começa o seu crescimento na mulher, que chega à seguintes dimensões de um modo geral: $10-11 \mathrm{~cm}$ de altura, $12-13 \mathrm{~cm}$ de largura, por $5-6 \mathrm{~cm}$ de espessura.

Diante de uma fecundação a mama passa a aumentar seu volume a partir de então até o quinto mês, quando pára de aumentar. Com o parto, a mama volta a aumentar em até três vezes o seu volume inicial. Com o fim da amamentação a mama volta ao volume inicial.(TESTUT.et al.(1978)). 


\section{2-Variações Fisiológicas da Mama ao Longo da Vida .}

Após o nascimento, a mama passa por um processo estável até a menarca, por volta dos 12 anos, quando sofre efeitos hormonais e passa a se desenvolver. Até esta fase, a mama tem dimensões diminutas. Os ductos nesta fase são bastante rudimentares e são desprovidos de ácinos. Com a menarca, a mama atinge maior peso e consegue uma protuberância típica das nulíparas, com um perfil levemente abaulado, lembrando o cone, sem ainda o efeito da gravidade sobre o seu colo, que a caracteriza. Após a menarca, a mama sofre efeito da gravidade, o que confere com o tempo uma certa queda, dando ao conjunto um perfil de movimento

Com a gravidez, logo após a fecundação, a mama passa a se desenvolver no sentido de ganho de volume e tamanho. Com a lactação, tende a ser mais pêndula e mais túrgida, aumentando o seu volume, e torna-se mais tensa, com contornos mais arredondados, de aparência mais nigurgitada. Com a chegada da senilidade, a mama assume um aspecto pendente e de desproporção entre o continente e o conteúdo, dando a impressão de sobra de pele ou de falta de glândula, o que faz com que a orientação do mamilo oriente-se no sentido caudal. (BLAND .et al.(1994) ; GRAY.(1977) ; PIATO.(1979 ); TESTUT.et al.(1978)).

A figura 5.2-1 demonstra estas variações, em nível macroscópico e microscópico. Vale a pena salientar que estas variações s̃o hormônios dependentes e pertinentes ao desenvolvimento normal da mulher. Em alguns disturbios endócrinos, estas variações sofrem distorções. Na mesma figura, podemos verificar o incremento que a unidade funcional da mama recebe, nas diferentes fases, vista em forma esquemática e em aparências nos cortes. 


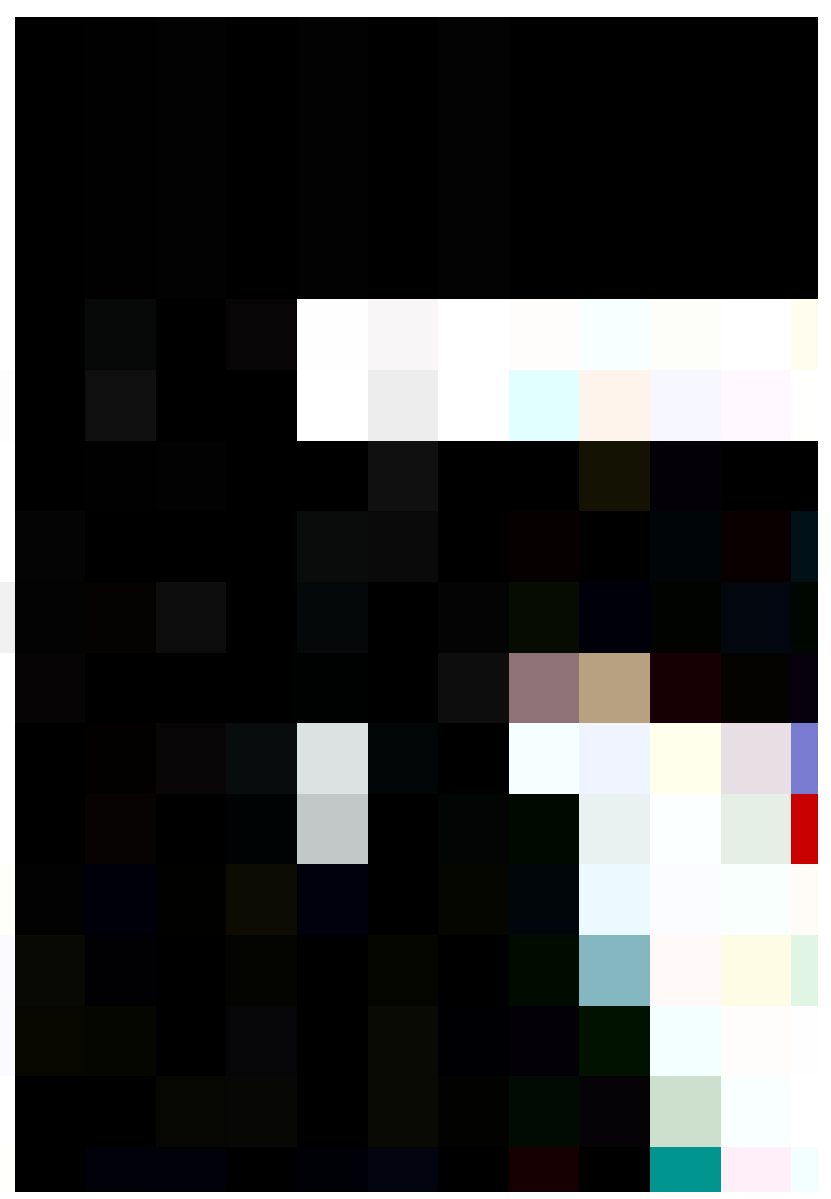

Figura 5.2-1. Desenvolvimento da mama: I e II anatômico de frente e de perfil; III esquemático da unidade funcional (ducto e lóbulo);IV aparência nos cortes histológicos. Aqui foram abordadas, as fases: (a) Pré-Púbere, (b) Puberal, (c) Adultas, Gestacionais, Lactantes, Senis. Fonte-BLAND et al .(1994).

Segundo MALBERGER et al (1986), o desenvolvimento verificado na mama é hormônio-dependente, sendo que o estrogênio estaria numa relação direta com a proliferação epitelial ductal , enquanto que a proliferação epitelial do lóbulo (acinar), estaria diretamente associada à atividade da progesterona. Esta associação de causa e efeito dos hormônios na mama é suportado por Frantz AG (1981) e Porter JC (1974). 


\section{3-Variações Clínicas ao Longo do Ciclo.}

A mama sofre mudanças notadas pelas mulheres que se queixam de uma sensibilidade aumentada, principalmente na metade superior. $\mathrm{Na}$ realidade as mulheres definem vagamente estas sensações proprioceptivas. Estas queixas perduram às vezes por 10 dias ao mês e até mesmo por anos ininterruptos. A maior parte das mulheres faz menção a um "peso vazio", que em algumas regridem com o fim da menstruação ou até mesmo dias após. Outras mulheres queixam se da sensibilidade apenas de uma certa região da mama, ou seja, como que o processo fosse localizado.( HAAGENSEN.(1987) ; BLAND.et al.(1994) ; MALBERGER et al (1986)),

Inúmeros trabalhos têm tentado responder a esta necessidade de se responsabilizar algo por esta sensação. Alguns de forma polêmica tentam comprometer as mudanças histológicas e de cunho citológico que a mama apresenta nesta fase, e de forma cíclica principalmente na fase luteal, como sendo a responsável por esta sensação muito referida pelas mulheres. Outra tentativa em vão foi a de demonstrar a retenção salina que haveria na fase folicular do ciclo. Os que negam a retenção salina e as mudanças da histo/citologia da mama apelam para a possibilidade destes sintomas serem causados pela engurgitação vascular. Estes mesmos autores responsabilizam a sintomatologia destas queixas clínicas, como sendo decorrentes de fenômenos vasculares. (HAAGENSEN.(1987) ; MALBERGER et al.(1986); ROBBINS et al.(1984); SYMMERS.(1978)).

Clinicamente, estas queixas podem ter como consequiência biopsias desnecessárias, mamografias desnecessárias, e a própria dor de difícil abordagem clínica, por falta de conhecimento científico dos motivos destes sintomas. A avaliação histológica destas áreas dolorosas da mama mostrou ser geralmente dbença fibrocística da mama, ou ingurgitamento fisiológico. (HAAGENSEN.(1987)) ; 


\section{4-Variações do Conteúdo de Água e Sal na Mama ao Longo do Ciclo Menstrual}

Um trabalho publicado por (OLSON et al, (1996)), estuda a influência da ingesta salina na sintomatologia cíclica menstrual. Estes autores estudaram 13 mulheres saudáveis menstruando, sem síndrome pré-menstrual, de idade entre 21 e 35 anos, pesando entre 50 a $80 \mathrm{Kg}$, recrutadas por um chamado pela mídia. Estas mulheres responderam um questionário sobre seus costumes alimentares, sobre a severidade de sua sintomatologia menstrual e colheram amostras de urina de 24 horas. Tiveram a ingesta e excreção de sódio controlada por 3 meses, sendo como o mês base em que fizeram uma dieta de $115 \mathrm{mmol} / \mathrm{d}$ seguindo os dois meses de restrição quando foi dado $73 \mathrm{mmol} / \mathrm{d}$.

No mês de base foi notado um decréscimo de cloro e do nível de sódio plasmático, assim como um decréscimo da excreção de sódio urinário. Além do sódio e cloro, foi dosada a renina, onde se constatou um decréscimo de sua atividade. Em relação à fase folicular houve um decréscimo dos níveis sódio plasmáticos na fase luteal, e um aumento da excreção de sódio urinário. Esta fase precede a sintomatologia mais exacerbada da mama. A sintomatologia mamária aumentou de 6 para 8 vezes na ultima fase luteal e o aumento objetivo da mama aumentou de 2 para 3 vezes, quando comparado com os meses de sintomatologia mais amena. A fase luteal de todos os ciclos foi acompanhada de aumento de sódio, e este aspecto independe da ingestão aumentada de sal.

As conclusões a que estes autores chegaram foi de que a sintomatologia da mama, tal como aumento de sensibilidade, não é decorrente da retenção do sódio da fase luteal. Foi verificado tanto em ciclos normais como em ciclos que sofreram restrição de sal que, na fase luteal, houve um balanço negativo de sal, ou seja, elas perderam sal e não fixaram. 


\section{5-Variações Citológicas da Mama ao Longo do Ciclo Menstrual.}

O fato de a mama apresentar sintomas cíclicos temporalmente relacionados com menstruação suscitou que o epitélio mamário, tal como o endometrial, respondesse com características morfológicas próprias. Estes aspectos têm atraído a atenção de vários pesquisadores no sentido de identificar características celulares e histológicas cíclicas pertinentes à mama. Pode-se citar (HAAGENSEN(1971), ROBBINS( 1984), SYMMERS(1978)) como exemplo de pesquisadores que se interessaram pelo assunto. Todavia estes autores negam que a sintomatologia cíclica tenha um componente celular ou histológico na mama, e afirmam que a sintomatologia seja decorrente de processo vascular e estromal. (MALBERGER (1987))

Já outro grupo de pesquisadores responsabilizam tal sintomatologia clínica e descrevem alterações em nível celular e histológico em caráter cíclico, como (FANGER et al (1974) e VOGEL et al(1981)).

Um trabalho bastante convincente de que existem alterações cíclicas celulares na mama é o de (MALBERGER et al (1987)), em que estudam as mudanças celulares pertinentes às fases do ciclo menstrual, e analisam as amostras colhidas através de fina agulha de aspiração, em fases pré e pós-ovulatória caracterizando as fases analisadas no microscópio óptico. Esta capacidade de discernir a fase do ciclo é testada no computador através de imagem digitalizada, onde se afere a concordância do método. Houve uma concordância de $84 \%$ quando as amostras eram de mulheres diversas e de $100 \%$ quando as amostras eram da mesma mulher.

Apesar destes autores objetivarem concluir quanto à natureza das características celulares morfológicas das mudanças, concluíram também que, além das mudanças, é aconselhável somente se fazer a punção biópsia aspirativa na fase folicular por ser esta fase mais fácil de se identificar as alterações de malignidade, pois na fase luteal existe a possibilidade maior de se cometer equívocos de observação e se confundir os achados normais com os de malignidade. Este aconselhamento é sustentado por (HAAGENSEN (1987) e por GONZALEZ (1986)). 
Malberger como autor, se posiciona a favor das mudanças que ocorrem de forma cíclica na mama, no âmbito celular e histológico, chegando a enumerá-las e que nós agrupamos de forma sinóptica na (Tabela 5.5.1), as características das duas fases em questão por ele observada.

Tabela 5.5-1.Correlação dos achados citológicos de Malberger, segundo as fases por ele observadas.

\begin{tabular}{|c|c|c|}
\hline & Fase Pré-Ovulatória. & Fase Pós-Ovulatória. \\
\hline Estrutura acinar. & $\begin{array}{l}\text { Células marginais mais } \\
\text { evidentes. }\end{array}$ & $\begin{array}{l}\text { Aumento da celularidade, } \\
\text { com } \\
\text { acinares. }\end{array}$ \\
\hline Citoplasma & Mais delineado & Rendilhado e frágil \\
\hline Margens & Mais evidentes & Desintegrada \\
\hline Núcleo & $\begin{array}{llr}\begin{array}{l}\text { Menor } \\
\text { cromatina }\end{array} & \text { de } & \text { compacto, } \\
\text { distribuição } \\
\text { homogênea, } & \text { nucléolos } \\
\text { imperceptíveis. } & \end{array}$ & $\begin{array}{l}\text { Cromatina orientada na } \\
\text { periferia, com nucléolo } \\
\text { proeminente }\end{array}$ \\
\hline Fragmento glandular & $\begin{array}{l}\text { Compactas e tendem a se } \\
\text { organizar em uma camada } \\
\text { estratificada }\end{array}$ & $\begin{array}{l}\text { Proliferativos, em } \\
\text { multicamadas com uma } \\
\text { superposição das células. }\end{array}$ \\
\hline
\end{tabular}

Um outro trabalho publicado que colabora com as evidências de que a mama apresenta atividade cíclica em nível celular é de.(OXUM \&.JERNSTROM (1987)). Estes autores estudaram 58 espécimes provenientes de resultados de mamoplastia redutoras em que se conheciam a história e a fase do ciclo menstrual das mulheres na época da cirurgia. Objetivaram estudar a predisposição aumentada para câncer de mama em pacientes que apresentavam a proliferação exacerbada na fase luteal. Acreditando ter uma relação direta com a tumorogenese. A proliferação da fase luteal foi correlacionada com peso altura, uso de contraceptivo antes da primeira gestação, histórico familiar de câncer de mama, paridade e uso hormonal. 
Estes autores encontraram um aumento da proliferação epitelial na fase luteal em comparação com a fase folicular nas mulheres que : usaram contraceptivo antes da primeira gestação; em uso de pílula; nas de menor altura; de menos peso; de histórico familiar positivo de câncer de mama e em mulheres relativamente jovens. Não houve diferença no grau de proliferação em mulheres que não usavam ou usavam ocasionalmente anticoncepcionais.

Outro trabalho que aponta para alterações celulares cíclicas na mama é o trabalho de (SODERQVIST et al(1997)) em que, além de fazer a punção aspirativa dosaram a progesterona e centraram a fase do ciclo em suas dosagens. Estes autores encontraram um aumento da celularidade na fase luteal em relação à fase folicular. Para mulheres com idade menor que 35 anos o incremento da celularidade foi de $2,29 \%$ na fase luteal e $1,13 \%$ na fase folicular e para mulheres com idade superior a 35 anos o incremento foi de 2,04\% na fase luteal e 1,66\% na fase folicular. Estes autores usaram como método anticorpos e leitura de concentração destes anticorpos. Ki-67/MIB-1.

GOING et al (1988), estudaram uma estimativa de mitose através do emprego da timidina tritiada em ciclos naturais e artificiais. Encontraram uma maior proliferação na segunda fase do ciclo ovulatório, ou seja, a fase luteal. Perceberam também uma maior quantidade de secreção intracitoplasmática e luminal na fase folicular, em ambos os ciclos tanto artificiais como natural. Mostraram também um conceito recente e inédito no estudo da variação da celularidade da mama, que é o conceito de apoptose que, segundo os autores, ocorreu por volta do dia 28 do ciclo natural. Em suma, eles notaram uma celularidade aumentada na segunda fase do ciclo tanto natural como artificial, assim como aumento de secreção citoplasmática e intraductal.

A variação da citologia da secreção mamilar foi estudada por Bland et al (1994). Estes autores citam alterações do padrão histológico, morfologia celular, mitose e conteúdo de DNA, relacionados com as fases do ciclo menstrual. Notaram uma atividade proliferativa celular e síntese de DNA aumentada na fase luteínica tanto em nível de ductos como de lóbulos. Que segundo eles, é decorrente de atividade hormonal combinada de estrogênio e progesterona. Citam a presença de degeneração e escamação celular, tal como a presença de linfócitos, e morte celular 
que culmina no dia 28 do ciclo. Estes dados estão de acordo com os achados de (GOING et al (1988)).

$\mathrm{O}$ efeito da progesterona exclusivamente na celularidade da mama foi estudado por SPEROFF.(1999). Este autor estudou a fase luteal, ou seja, a fase em que a progesterona oferece um pico de secreção e que os níveis plasmáticos estão relativamente altos. $\mathrm{O}$ autor contabilizou algumas alterações, como no final da fase luteal a mama atinge o seu maior tamanho e notou-se grande atividade mitótica e secreção fluida nesta fase, assim como uma maior síntese de DNA. Estas vertentes são responsáveis pelas mudanças da mama na fase pré-menstrual. Outra observação do autor é quanto à variação dos receptores hormonais tanto para estrogênio, como para progesterona, concluindo que os receptores estrogênios decaem durante a fase luteal e os receptores progesterônicos mantêm-se inalterados durante todo o ciclo.

Vale a pena salientar que Papanicolaou em 1958 fez citação de aumento da proliferação celular e de vacuolização celular, na citologia da secreção mamilar, mas não fez associação com o dia do ciclo, embora citasse fatores endócrinos da paciente. (BLAND et al (1994)).

\section{6-Variações da Histologia da Mama ao Longo do Ciclo Menstrual.}

Um trabalho bastante enfático de que a mama sofre profundas alterações histológicas, que se correlacionam com as fases do ciclo é o publicado por (VOGEl et al (1981)), aqui com ênfase em alterações histológicas.

O material foi obtido de espécimes cirúrgicas decorrentes de mamoplastias de redução e mastectomias subcutâneas, provenientes de mulheres sabedoras de suas fases do ciclo menstrual e sadias, para que qualquer doença não estivesse interferindo no eixo hipófise ovariano. Foram selecionadas 173 mulheres que se submeteram à mastectomia subcutânea e mamoplastia redutora entre agosto de 1978 e dezembro de 1980, nenhuma delas foram operadas por serem portadoras de neoplasias. Deste universo, selecionaram-se 90 pacientes que tinham o ciclo 
menstrual regular de 28 dias, que não estavam usando hormônios, sem doenças vicariantes, sem uso de medicamentos que pudessem interferir no eixo hipófise/ ovariano. Tais mulheres tinham entre 16 e 51 anos e nenhuma paciente engravidou depois da cirurgia por 2 anos. Estes tecidos foram devidamente preparados, e corados pelo método $\mathrm{H} / \mathrm{E}$ e observados por experientes patologistas.

O resultado foi uma grande variação da histologia parenquimatosa e estromal, que possibilitou o agrupamento das características histológicas em grupos temporais, em 5 fases de respostas morfológicas: FFase Proliferativa (do dia 3 ao dia 7); II-Fase Folicular de Diferenciação (do dia 8 ao dia 14); III-Fase Luteal de Diferenciação( do dia 15 ao dia 20); IV-Fase Secretória( do dia 21 ao dia 27); V-Fase Menstrual( do dia 28 ao dia 2).

\subsubsection{I-Fase Proliferativa}

Esta fase se caracteriza pela presença de mitoses e morfologia celular constante. No dia 3, o número de mitoses foi inferior aos dias 5,6,7. Os lóbulos continham células tanto acinares como ductais, compostas de um tipo de célula única dominante com morfologia poligonal, que se arranjavam em 2 e 3 camadas.Estas células tinham o citoplasma pálido homogêneo e eosinofílico, com núcleos centrados, nucléolos proeminentes, membrana citoplasmática apagadas e relativamente pouco orientadas para o lúmem. Figuras de células apoptóicas foram verificadas nesta fase, o lúmem acinar e ductal eram estreitos ou ausentes. O produto secretório no lúmem lobular era escasso.

\subsubsection{II-Fase Folicular de Diferenciação}

Nesta fase não existiu um tipo celular dominante, mas observaram-se dois tipos de células que se associavam à célula mais comum da fase proliferativa, estas células eram: célula basal de citoplasma claro e núcleo pequeno hipercromático, célula luminal colunar com citoplasma basófilo e de localização basal. As células luminais com orientação radial e bordas evidentes o que delimitava se melhor o lúmem. No lúmem se observou pouca secreção e pouca atividade secretória pelas células. A celularidade diminuiu e o tecido calagenoso exacerbou se em relação à fase proliferativa. 


\subsubsection{III-Fase Luteal de Diferenciação}

Nos lóbulos observados foram identificados três tipos celulares:colunar, sendo basofílicas que delimitavam o lúmem ductal e lobular; pálidas, sendo eosinofílicas normalmente basais; claras, de formato virgulóides.

Notou-se vacuolização, e células basais plectóricas, com lúmem menos estreito, com produtos secretórios. Aqui a lâmina basal tornou se menos evidente e não se notaram figuras mitóticas.

\subsubsection{IV-Fase Secretória}

Nesta fase as células luminais foram tipicamente de secreção apócrina com vacuolização citoplasmática e lúmem bem evidente.

O manto estromal se tornou edematoso, com dilaceração do manto das bordas lobulares. A lamina basal era tênue e delicada. Os vasos venosos eram congestos.

\subsubsection{V-Fase Menstrual}

Esta fase se caracteriza por dois tipos distintos de células: basais com citoplasma claro sustentando células luminais de citoplasma claro, com núcleo endentado e lúmem aumentado, sem secreção. O estroma era fino e celular,em que ocasionalmente se notaram células inflamatórias. Não se notaram mitoses.

A abordagem deste autor deixa claro que a mama sofre profundas alterações histológicas, que se correlacionam com as fases do ciclo menstrual, permitindo-lhe a possibilidade de elencar fases, de descrever alterações notadas na microscopia e bem documentadas numa apreciação basicamente microscópica e por patologistas. Ficou claro também que as alterações não são circunscritas à arquitetura tecidual ou somente à analise da células mas ao estroma e vascularização.

Watson et al (1987) publicaram um trabalho mostrando as alterações confinadas única e exclusivamente à lamina basal, que como sabemos, é a sustentação do epitélio do tecido epitelial de um modo geral.

Estudaram espécimes histológicas provenientes de 19 mulheres nulíparas, de ciclo menstrual regular, que sabiam com certeza do primeiro dia do ciclo. Tinham 
feito mamoplastia redutora e/ou exérese de fibroadenoma. Os autores pode deslumbrar 3 variantes morfológicas da lamina basal. Em todas as espécimes existiam reduplicação da lamina basal em algumas áreas, que foram descritas previamente como traço patológico. Verificaram também ramificação da lâmina basal dentro do tecido conectivo periductal. Em algumas ramificações havia processos citoplasmáticos e em quase todos eram vistos hemidesmossomos. Uma terceira variação consta de invaginações da lâmina basal para a bainha estromal colagenosa.

A reduplicação foi vista em todos os estágios do ciclo menstrual. Entretanto, ramificações foram mais comuns na fase periovulatória e no início da fase luteal. Estes aspectos falam a favor de que estas alterações são decorrentes de variações hormonais fisiológicas do âmbito do ciclo menstrual. 


\section{Capitulo 6 - Proposta Geral e Metodologia}

Em ambulatórios de mastologia, uma queixa muito comum é o desconforto experimentado pelas mulheres em fases diferentes do ciclo menstrual. Este desconforto é referido como uma sensação de peso, ardência e dor, mais acentuada nos quadrantes superiores de ambas as mamas, sensação que pode perdurar por dias semanas meses ou anos, oscilando durante um ciclo menstrual.

O médico pode identificar alterações na textura da mama assim como no volume, uma vez dotado deste interesse.O volume é notado aumentado antes da menstruação de uma forma flagrante, em algumas mulheres mais e em algumas mulheres menos. Pode ainda notar que determinadas regiões são mais e outras são menos doloridas, em fases diferentes do ciclo menstrual. Mais que isto, pode ser capaz de dentificar nodularidades de contorno e volume diferentes em determinadas fases do ciclo menstrual. Ainda pode testemunhar o aparecimento ou $\mathrm{o}$ desaparecimento de nodularidades que variam com as fases do ciclo.

Vale salientar que estas sensações que se associam ao ciclo menstrual relatadas pelas mulheres, têm uma tendência a ser idênticas em ambas as mamas, e de forma simétrica. A nodularidade também tem uma tendência de ser simétrica e idêntica , mas são relatados casos de apresentação assimétrica. (BLAND et al.(1994)).

Estas queixas tendem a diminuir de uma forma branda com a vinda da menopausa. Já na fase em que os ciclos se tornam irregulares a mulher relata uma ligeira melhora, mas é comum persistir os sintomas, mesmo depois da menopausa. Aliás, é comum o relato de sensação de peso na mulher que está fazendo reposição hormonal, ou que está gozando de ciclos artificiais. (HAAGENSEN (1987)).

As mulheres nulíparas, têm uma tendência a ser mais acometidas destes sintomas, principalmente os sintomas relacionados à nodularidade. Já o 
ingurgitamento tende a ser mais pronunciado por volta da menopausa. .(HAAGENSEN (1987)).

O fato de estes fenômenos serem cíclicos, e pertinentes ao ciclo menstrual sugere que deve estar relacionado com o ciclo nos hormônios sexuais das mulheres.Houve muitas tentativas de se encontrar uma característica histológica que pudesse se associar às fases do ciclo menstrual. (ROSENBERG, A.(1922) ; DIECKMANN,H.(1925)). O capitulo anterior, aborda estas variações de uma forma sistemática. Na realidade, o assunto é polemico, e formaram-se grupos de autores que defende uma variação constatada pela histologia e um grupo de autores que defende que não existe uma variação histológica da mama, pertinente ao ciclo menstrual. Por outro lado, o grupo de autores que defendem que não existe a variação da histologia, justifica a sintomatologia da mulher tal como o aumento da nodularidade e do volume através de uma variação da vascularização da mama, em períodos do ciclo menstrual. (MALBERGER.et al (1986)).

Independentemente de ser variações histológicas ou variações de ordem vascular, é real e constatado por todos que o volume da mama assim como a textura sofre variação no decorrer do ciclo menstrual.

Esta vertente é fundamental, pois interfere diretamente na qualidade dos mamogramas no que tange à capacidade de denunciar uma área circunscritamente mais densa, visto que a identificação de uma área mais densa, requer a formação do contraste entre a área em questão e os demais campos da mamografia.Este trabalho se dirige aos demais campos do mamograma e não esta dirigido de forma direta, para a área densa. Por outro lado, o presente trabalho este trabalho esta voltado para o estudo da relação entre a área densa e os demais campos do mamograma, no que se refere ao contraste promovido.

A mamografia nos moldes em que o exame é concebida atualmente, não valoriza estas variações, e parte do princípio de que as tomadas das imagens não sofrem variação da densidade se comparadas fases diferentes do ciclo menstrual. Entretanto, o estudo da variação da mama feminina se deu em instância histológica por vários autores e não no âmbito da radiologia.

A mama responde a muitos hormônios, e não somente aos hormônios sexuais. Assim a mama responde á insulina, hormônio do crescimento, prolactina, 
triiodotironina, tetraiodotironina, mineralocorticóides, glicocorticoides, hormônios tireotróficos, hormônio folículo estimulante, hormônio luteinisante etc. (HAAGENSEN (1987)).

A proposta deste estudo então é averiguar e quantificar a variação da densidade da mama ao longo do ciclo menstrual, para identificar fases ou dias de fases em que a densidade seja maior e fases ou dias de fases em que a densidade seja menor, sem evidenciar se a variação esta sendo causada por este ou aquele hormônio, para mulheres na pré-menopausa.

$\mathrm{O}$ ideal seria que o estudo fosse realizado em mulheres com várias tomadas ao dia, durante vários ciclos menstruais, pois no grupo de hormônios que efetivamente atuam na mama, existem os hormônios que variam de dosagem em horários diferentes do dia. Também em grupos de mulheres, com história de paridade equivalentes, história de uso de anticoncepcional semelhante, sem endocrinopatias etc. Entretanto, para fazer tomadas em mulheres várias vezes ao dia estariamos incorrendo em questões de bioética, tornando o projeto inviável.

Assim, a solução encontrada foi a avaliação em nível experimental usando se um animal. A determinação da espécie do animal foi norteada por algumas diretrizes óbvias. O animal necessariamente deveria ser um mamífero, estar disponível em nosso meio, com ciclo menstrual por volta de 30 dias, com variação dos hormônios sexuais conhecida, com a mama em dimensões passíveis de ser radiografada por um aparelho radiográfico convencional.

Os caprinos foram considerados e satisfazem estas exigências biológicas, pois tem um ciclo por volta de 21 dias, com níveis dos hormônios sexuais conhecidos e com mamas de dimensões adequadas para serem radiografadas.

Neste animal serão feitos três procedimentos diários, durante 21 dias, no mesmo horário: duas tomadas de radiografias da mama com a mesma técnica, coleta de citologia vaginal, coleta de sangue para dosagem dos hormônios :estradiol e progesterona.

O resultado radiográfico foi analisado de forma tanto subjetiva como objetiva. Após avaliado por 10 radiologistas estes elegeram o mamograma de maior densidade e o de menor densidade.As dosagens de hormônios foram lançadas em um gráfico de 
forma a poder ser situado o dia correspondente das mamografias, tendo como referencia o dia ovulatório e a fase folicular e luteal.

De forma objetiva estes mamogramas foram digitalizados e analisados por um "software", capaz de analisar os pixel da imagem digitalizada em um degradê do branco ao preto, numa escala que varia de (0 a 4096) níveis de cinza.

Uma vez analisados os mamogramas foram selecionados dois mamogramas sendo um de maior e outro de menor densidade. De posse das dosagens dos hormônios, foram identificados os dias e as fases destes dois mamogramas, perante o ciclo fisiológico do animal.

As inferências para as mulheres, foram feitas através da análise de mamogramas de mulheres que tiveram que repetir as tomadas por questões diversas, mas em dias do ciclo correspondentes aos dias em que se observou no experimento a maior e menor densidade, e que haviam declararado os dias de seus ciclos, através da identificação do primeiro dia do fluxo menstrual.

\section{1-Materiais e Métodos.}

É prudente, de ante mão deixar claras algumas faces da parte experimental deste estudo . Apesar de em veterinária a radiologia ser bastante usada, não se estuda a mama através dos Raios-X, nem mesmo na cadela em que o câncer de mama é muito freqüente. Mesmo porque a mamografia desenvolveu-se a partir de um aparelho inespecífico de Raios-X, e se deu no sentido de diagnosticar o câncer de mama na mulher o que trouxe um confinamento do aparelho somente para uma situação exclusivamente feminina. Assim, dispõe-se de aparelhos de Raios-X adaptados para situações de veterinária, mas não temos mamógrafos com finalidade veterinária.

Neste experimento foi usado, com o rigor técnico, um aparelho de Raios-X convencional de uso diário no Departamento de Radiologia da Escola de Veterinária de Jaboticabal ( UNESP). Deve se ressaltar que, o mamógrafo na atualidade está de 
tal forma adaptado à condição da mulher, que seria impossível posicionar um animal no mamógrafo.

Tentou se então, condição semelhante à do mamógrafo convencional, mas com técnica ajustada para adquirir uma imagem suficiente para se avaliar a variação da densidade da mama como um todo e sem se preocupar com a identificação de lesões.Por outro lado, ajustou-se a técnica no sentido de se visibilizar o tecido fibroglandular da mama do animal e assim poder analisar a densidade mamaria do ponto de vista radiográfico.

Muito importante também foi o rigor com que a técnica foi mantida, comprovado pela análise dos mamogramas digitalizados.

\subsection{1-Considerações Iniciais}

A identificação de um animal que pudesse servir para ser avaliada a densidade mamográfica iniciou com a proposta de animais de pequeno porte, tal como cadela, coelha, macaca, e até de grande porte como a vaca.

A cadela foi descartada por ter um ciclo longo por volta de 6 meses. A coelha não satisfez por ter a mama muito exígua, de difícil identificação pelos Raios-X. Todavia, seria uma grande opção, pois todos os experimentos de hormônios sexuais foram desenvolvidos em coelhos, o que traz benefícios, pois já se conhece o comportamento hormonal, e com detalhes. A macaca é um animal de difícil trato, e para se posicionar todos os dias no aparelho de Raios- $\mathrm{X}$ teria que ser sedada, o que poderia variar o eixo hipotalâmico, alterando a secreção de hormônios gonadotroficos, e a vaca apesar de possuir um ciclo estral pequeno, não foi possível se concluir com relação à técnica, por não se conseguir visibilizar o tecido fibroglandular, em níveis de tensão de faixa de funcionamento do aparelho.

Os caprinos enfim satisfizeram os requisitos necessários, conforme previamente comentado. Conseguimos 12 animais de criadores da região de Ribeirão Preto. Usamos o ultra-som para descartar os animais que estavam prenhas, idade, tamanho da mama, historia de prenhez fez parte de fatores para selecionarmos o animal do experimento. Assim selecionamos uma animal. 
O processo exige que este animal se submetesse a uma tomada radiográfica ao dia por 21 dias, que é o ciclo dos caprinos. Uma coleta de sangue diária foi feita através de uma punção venosa, assim como uma coleta de citologia vaginal. Todo estes procedimentos foram feitos de forma a não causar um "stress" a ponto de interferir no eixo hipotálamo/hipófise do animal.

A Escola de Veterinária de Jaboticabal (UNESP), especificamente o Departamento de Radiologia, Departamento de Reprodução e o Departamento de Patologia, se prestaram a executar o experimento. Nesta instituição desenvolveu se a técnica de radiografia mamária em cabras, fizeram-se as tomadas propriamente ditas, revelaram-se os filmes em tempo imediato. Fizeram-se as coletas de sangue e de material vaginal. As lâminas da citologia vaginal foram processadas no Departamento de Patologia desta instituição. Já o sangue foi processado no Departamento de Farmacologia de Ribeirão Preto (U. S. P).

O experimento fi realizado em junho de 2001, entre os dias 06 e 29 no que diz respeito à tomadas de imagem, mas se prolongou até o dia 07/07 de 2001 coletando se sangue e material vaginal.

\subsection{2-O Animal.}

No Brasil existem varias raças de caprinos. O animal selecionado foi da raça Saanen, comum em criadouros que visam à produção de leite. Um animal adulto pesando $49 \mathrm{~kg}$, criado em capril destinado à produção de leite e que esteve varias vezes prenha.

Vale salientar que, do ponto de vista reprodutivo, a cabra é tida como fêmea poliéstrica estacional. O ritmo e a estação que ela vai ciclar depende da incidência solar e da disponibilidade de alimentos. No Nordeste do Brasil, a cabra cicla de forma ininterrupta, mas no Sudeste apenas alguns meses do ano. Usa-se a aproximação do macho (rufiar) e observa-se o comportamento da fêmea. O interesse aqui dos criadores é no dia do estro, ou seja, do cio, que é o período da ovulação. O animal usado neste experimento foi avaliado por veterinários e que concluíram que a cabra estava ciclando no período em que se iniciou o experimento. 
Importante estar bem correlacionadas, neste experimento, as fases estrais da mulher com as fases estrais da cabra. A fase folicular da mulher é caracterizada por ser a fase do ciclo em que predomina o perfil estrogênico, assim como na cabra, para esta dá-se o nome de próestro. A fase ovulatoria da mulher é a fase estral na cabra, que dura em torno de 96 horas. A fase luteal da mulher é a fase metaestro e diestro da cabra. Contudo, neste experimento o importante é que o comportamento dos hormônios sexuais da cabra aconteça num sincronismo idêntico ao da mulher, em referência ao hormonio luteinizante, hormonio folículo estimulante, estrogênios e progestágenos. Portanto, o animal é passível de ser observado, quando se quer avaliar estes parâmetros, ou dados deles dependentes, como é o caso deste estudo.

Os fenômenos observados na mulher com relação ao sincronismo hormonal, acontecem em 28 dias e na cabra em 21 dias, todavia em ritmo e seqüência idênticos , pelo menos nos hormônios que aqui se observaram.

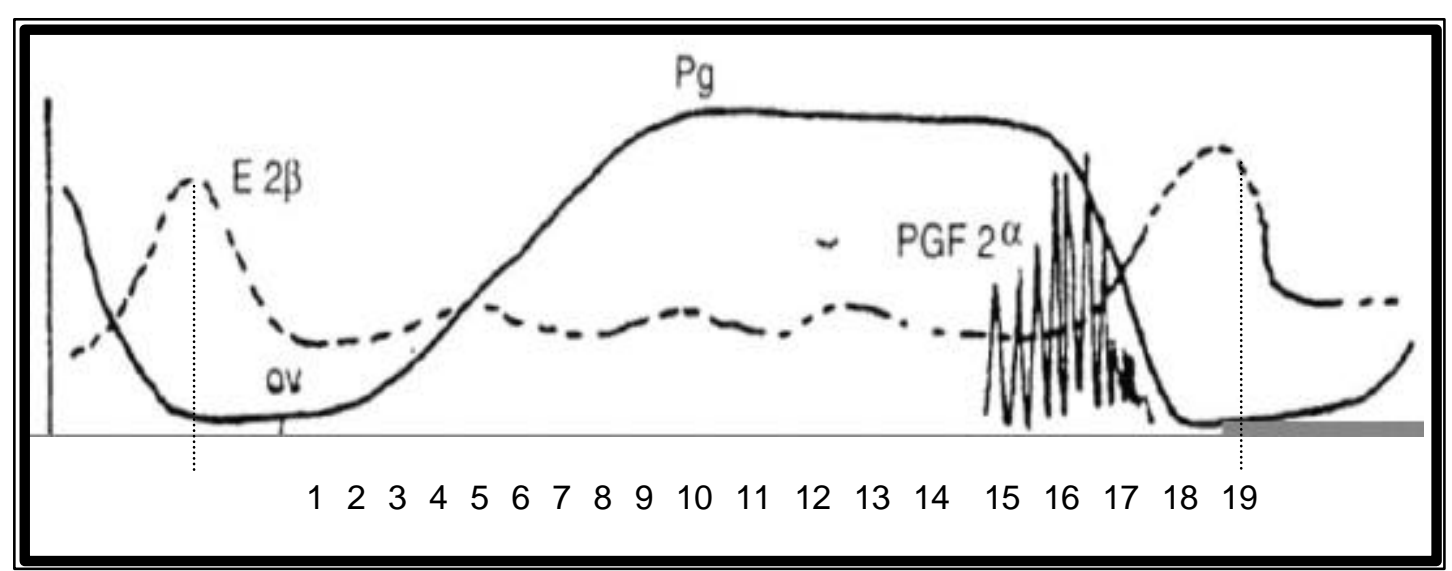

Figura 6.1-1- Gráfico esquemático da variação fisiológica dos hormônios Estradiol e Progesterona dos caprinos em 1 ciclo estral , notar que no terceiro dia ocorre a ovulação. Fonte: Chemineau (1993)

\subsection{3-O Aparelho de Raios-X.}

Foi usado o aparelho de uso rotineiro fixo do Departamento de Radiologia da Escola de Veterinária de Jaboticabal (UNESP). O aparelho é da marca Tur Dresdem, 
800mA de origem alemã. Este aparelho se movimenta tanto na vertical como na horizontal, com mesa de apoio que também oferece possibilidade de movimento.

\subsection{4-O Instrumento de Compressão da Mama.}

A compressão da mama em mamógrafos é rotina. Tem a propriedade de uniformizar a espessura, imobilizar e de diminuir a probabilidade das imagens se sobreporem, na medida em que comprime em apenas um sentido, tornando as estruturas internas melhores identificadas, pois elas se "esparramam". Estes dispositivos estão disponíveis, porém em mamógrafos.

Todavia, para se conseguir os mesmos efeitos nas tomadas de imagem da cabra, foi elaborado um instrumento, que conseguiu boa compressão, mas não da mesma forma quanto àimobilidade.

Consta de uma plataforma de metal, maior em $2 \mathrm{~cm}$ que o chassi, em todos os seus lados. A um $1 \mathrm{~cm}$ dos cantos, e em cada canto foi fixado um eixo de metal de formato cilíndrico, por volta de $7 \mathrm{~mm}$ de diâmetro. Neste eixo de $10 \mathrm{~cm}$ de comprimento, em sua extremidade oposta à fixada na plataforma, implantou-se um sistema tipo rosca sem fim, por onde se instala uma porca manual. Abaixo desta porca se fez passar uma mola espiral de arame de aço, do mesmo tamanho nos quatro eixos, de $3 \mathrm{~cm}$. Abaixo desta mola espiral se implantou uma outra plataforma das mesmas dimensões da plataforma base, porém de acrílico. $\mathrm{O}$ chassi com o filme se sobrepõe à plataforma base e fica imediatamente em contacto com a mama, que sofre compressão por força exercida pela mola sobre a plataforma de acrílico. Observe a (Figura 6.1.2) 

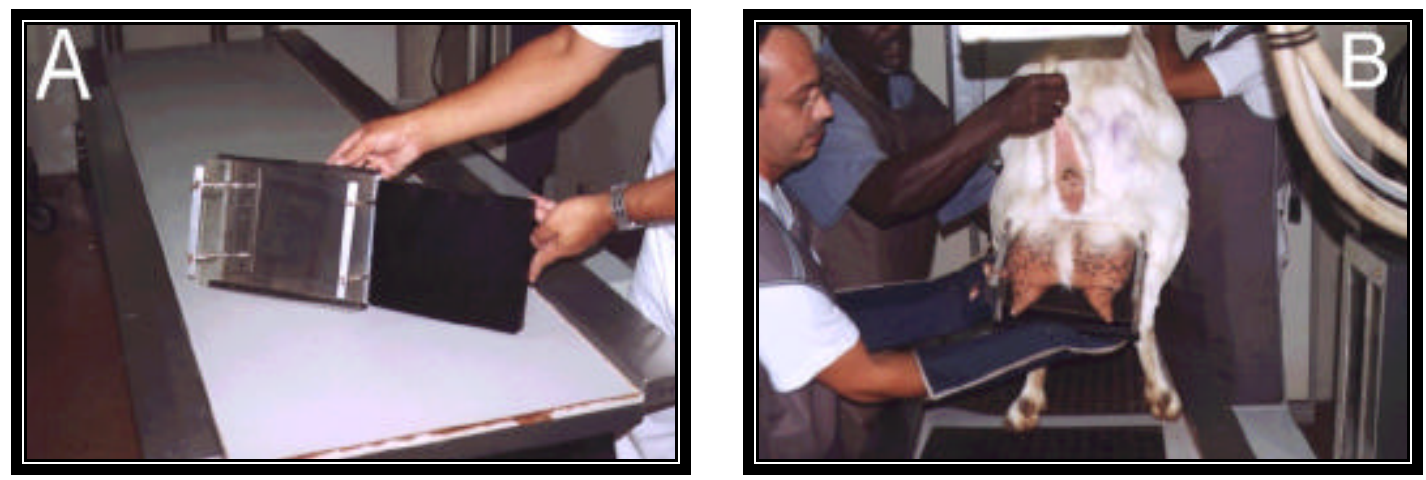

Figura 6.1-2. A) Fotografia do aparelho compressor da mama e chassi sendo colocado no aparelho.B) Fotografia do aparelho sendo usado na tomada de mamografia, em posição ortostática da cabra.

\subsection{5-O Filme Radiográfico.}

Usou-se o filme Mr.2000 específico para mamografias, considerado pelo fabricante (KODAK), como sendo de alta sensibilidade.

\subsection{6-Material de Coleta de Sangue.}

Para se colher o sangue usou se material descartável e sistema fechado de coleta de sangue. Este sistema porta uma agulha que vem em continuidade com o recipiente que deverá de receber o sangue em volume já preestabelecido, aqui por volta de $5 \mathrm{ml}$, já com anticoagulante (heparina sódica). Usou se também para armazenar o resultado da centrifugação recipientes de plástico individual e hermeticamente fechado.

\subsection{7-Material de Coleta de Citologia Vaginal.}

Vale salientar que em mulheres colhem-se citologias vaginais, cervicais e endocervicais. A coleta é feita mediante a visualização do canal vaginal, proporcionada pelo espéculo vaginal. A vaginal é a mais expressiva para se identificar a fase do ciclo estral, por ser mais dotadas de receptores estrogênios.Portanto trata se de uma coleta dirigida. Todavia a citologia cervical também expressa as variações do ciclo estral, mas não de forma tão típica como a 
vaginal. Já a colheita do material endocervical é feita mediante o uso de uma escova. Pelo fato de não ser de uso rotineiro em veterinária a coleta de citologia vaginal em caprinos, e por isso não se dispor de um espéculo de vagina de caprinos, foi usado aqui uma haste com um tufo de algodão em uma extremidade tipo cotonete.

\section{2-Método de Aquisição dos Mamogramas da Cabra.}

Não é de uso rotineiro, mamografias em caprinos. Portanto, a técnica teve que ser desenvolvida nas dependências do Departamento de Radiologia da Escola de Veterinária de Jaboticabal (UNESP); Supervisionada pelo Prof. Dr. Julio Carlos Canola.

O animal, após manejo apropriado, a favor de não causar "stress", era trazido da baia para o Departamento de Radiologia, sendo conduzido por um enfermeiro, caminhando, por uma distância de 50 metros.

Iniciaram-se as tomadas com o animal em posição "sentada". Isto é, com dois enfermeiros segurando o animal, de forma que os membros anteriores ficavam erguidos e os posteriores no chão. Por entre os dois membros posteriores, e junto ao solo se colocava o chassi, sobre o qual repousava o par de mamas comprimidas. Com um aparelho de Raios- $X$ portátil se tomava a imagem, no sentido crânio caudal.Esta técnica mostrou-se inviável, visto que o animal fica em posição desconfortável dificultando o posicionamento estático.

Iniciou-se então, uma técnica com o animal em posição ortostática. Nesta técnica, o animal é colocado por sobre a mesa do aparelho de Raios-X fixo, e por entre os membros posteriores se coloca o compressor do par de mamas. A ampola do aparelho posicionada posteriormente ao animal emite na incidência caudo-cranial. Vale lembrar que no compressor se encaixa o chassi com filme radiográfico.

Foram testada varias tensões, distâncias e tempos de exposição, e após várias tentativas de se conseguir visibilizar o tecido fibroglandular, chegou-se à tensão de $35 \mathrm{kv}, 25 \mathrm{~mA}$, tempo de exposição de 0,1 segundo, e a uma distancia de $60 \mathrm{~cm}$.

Por todo o experimento foi usada esta técnica, o que não poderia deixar de ser, e a regularidade foi confirmada pela densidade óptica. 
Em todo o período de duração do experimento a exposição foi feita pelas 09:00hs, com duas tomadas e com uma diferença de 15 minutos entre cada tomada.

\section{3-Método de Aquisição dos Mamogramas Femininos.}

A partir dos resultados observados nos radiogramas obtidos da cabra, (conforme apresentados no próximo capítulo), foram destacados dois momentos de interesse na investigação: fase ovulatoria e fase luteal.Essa inferência levou a extender a avaliação experimental em busca de uma comparação mais direta com o comportamento das imagens mamográficas da mulher. Para essa comparação então , forma pesquisados exames mamográficos que possibilitassem selecionar imagens que tivessem sido obtidas nos períodos de interesse pré-determinado.

Assim foram pesquisados vários casos para se identificar alguns particulares que se encaixassem nos requisitos.

Essa pesquisa foi feita no ambulatório de mastologia da Prefeitura Municipal de Matão, através do arquivo das fichas clínicas de pacientes que tinham se submetido a duas mamografias em tempos diferentes. De posse destas fichas e de suas respectivas mamografias, foram selecionadas as que foram radiografadas coincidentemente na fase ovulatoria e luteal do mesmo ciclo. Não se questionando outro fator, tal como historia obstétrica, uso de anticoncepcional, idade etc. Dessa investigação resultaram 11 casos em que se verificou a coincidência necessária e então foram requisitados os respectivos mamogramas para análise. 


\section{Capitulo 7 - Resultados}

Os resultados aqui apresentados foram ordenados de uma forma tal simulando a ordem dos acontecimentos e de interesse do experimento.Assim expõem se primeiro os resultados da análise hormonal do animal em sua totalidade, que terá como consequiência, evidências importantes do experimento,indicando se o animal esta ou não ciclando, e o comportamento dos hormônios no período analisado, para identificarmos as fases luteal e folicular, assim como a fase periovulatória. O resultado, da citologia vaginal, é consequiência do ciclo hormonal do animal e corrobora com tal evidencia.

A interpretação das mamografias do animal passou por avaliação subjetiva, perante 10 especialistas. Estes mesmos mamogramas foram digitalizados e objetivamente através de software específico para densidade mamográfica (Nunes F.L.S et al (2001)). Posteriormente, entre os mamogramas selecionados das 11 mulheres selecionadas foi feita analise semelhante.

\section{1- Considerações Iniciais.}

Alguns aspectos devem ser explicitados aqui. A veterinária segue seus caminhos, que são predominantemente econômicos, portanto a atividade sempre visa finalidades econômicas, que no caso dos caprinos centra se ou na produção de leite ou na produção de carne. A identificação do estro através do rufiar, satisfaz as necessidades do criador. Fato é que poucas informações se têm com relação à citologia vaginal dos caprinos.Todavia é um método muito importante na mulher, por ser capaz de identificar patologias vaginais inflamatórias e neoplásicas, assim como posicionar a fase do ciclo estral. De tal forma, que a interpretação destes dados aqui, 
é uma incursão do raciocínio analógico de um experiente patologista. Pois não se têm parâmetros bem estabelecidos das citologias vaginais de caprinos. Por outro lado a citologia vaginal aqui neste experimento tem apenas a finalidade de sustentar o ciclo, previamente caracterizado pelas dosagens hormonais. Contudo, é sabido que a citologia vaginal dos caprinos refletem as fases do ciclo estral. Resolvemos descartar estes dados, até porque estes são apenas confirmativos, e junto aos resultados das dosagens hormonais tem pouco peso na identificação da fase estral.

A figura 6.1-1 mostra o comportamento hormonal do ciclo dos caprinos, e evidencia os hormônios progesterona e estradiol. Exatamente os hormônios por nós dosados neste experimento.Note que o primeiro dia do ciclo, ocorre quando o Hormonio Luteinizante tem um pico de intensidade. Neste momento, o estradiol esta decaindo e a progesterona está basal. A ovulação ocorre 3 dias após este evento.e a progesterona somente vai atingir o pico 5 dias depois, (Figura 6.1-1) isto se da no dia 08.Chamamos de fase luteal a fase que vai desde a ovulação ate a luteolise, que naquela figura ocorre no dia 17, quando a secreção de progesterona volta em níveis basais, e o ciclo reinicia-se.Todavia junto com o início da queda da progesterona , os níveis de estradiol voltam a aumentar para fazer novamente a curva típica.

Colheu-se material durante 21 dias para que um aclo fosse coberto, epor questão de segurança, ainda foi colhido material por mais 3 dias para as imagens mais 13 dias para sangue e citologia vaginal. Enquanto a figura-6.1-1 demonstra o comportamento fisiológico dos hormônios dos caprinos, a figura-7.2-1 denota o resultado de nosso experimento, onde podemos notar que a fase luteal somente foi atingida no dia 26/06/01 que se manteve até o dia 09/07/0, a partir de quando se nota uma queda súbita, exatamente a luteólise. $\mathrm{Na}$ realidade a fase luteal propriamente dita, somente foi observada nos últimos 3 dias, ou seja, no dia 29, 28, 27, de nossas 24 tomadas.

Acreditamos que o "stress" do experimento tenha causado um bloqueio do hormonio luteinizante no animal, e que o pico progesterônico observado no dia 15 , deva-se a uma eventualidade biológica do experimento.Provavelmente o animal ovulou 5 dias antes, por volta do dia 10/06/01, mas o corpo lúteo não se manteve secretor, por carência do estímulo do hormonio luteinizante. Pelo que se vê na figura-7.2-1 a fase luteal patente, é a fase que se incia no dia 26/06/01. Acreditamos 
que o animal tenha ovulado no dia 20/21/06/01.Portanto, o corpo lúteo manteve-se trófico a partir do dia 26/06/01. Então interpretamos o período de 06 a 26 como sendo uma fase folicular, com a intercorrência do dia 15 já mencionada.

\section{2- Resultados das Dosagens Hormonais.}

Os resultados das dosagens dos hormônios do animal serão apresentados em forma de tabela e gráfico:

Tabela 7.1 Esposição da Dosagem diária de Estradiol e Progesterona do dia 06/06 até 09/07, indicando a fase do ciclo

\begin{tabular}{|c|c|c|c|}
\hline Data & Fase do Ciclo & $\begin{array}{c}\text { Dosagem de } \\
\text { estrogênio } \\
\text { ng/ml }\end{array}$ & $\begin{array}{c}\text { Dosagem de } \\
\text { Progesterona } \\
\text { ng/ml }\end{array}$ \\
\hline $06 / 06 / 01$ & Folicular & 0,0219 & 0,20 \\
\hline $07 / 06 / 01$ & Folicular & 0,0242 & 0,13 \\
\hline $08 / 06 / 01$ & Folicular & 0,0236 & 0,10 \\
\hline $09 / 06 / 01$ & Folicular & 0,0139 & 0,07 \\
\hline $10 / 06 / 01$ & Folicular & 0,0183 & 0,07 \\
\hline $11 / 06 / 01$ & Folicular & $*$ & 0,08 \\
\hline $12 / 06 / 01$ & Folicular & $*$ & 0,09 \\
\hline $13 / 06 / 01$ & Folicular & $*$ & 0,14 \\
\hline $14 / 06 / 01$ & Folicular & 0,0150 & 0,09 \\
\hline $15 / 06 / 01$ & Pico progest & 0,0311 & 80,11 \\
\hline $16 / 06 / 01$ & folicular & * & 0,37 \\
\hline $17 / 06 / 01$ & Folicular & 0,0166 & 0,29 \\
\hline $18 / 06 / 01$ & Folicular & $*$ & 0,16 \\
\hline $19 / 06 / 01$ & Folicular & 0,0300 & 0,41 \\
\hline $20 / 06 / 01$ & Folicular & * & 0,21 \\
\hline $21 / 06 / 01$ & Folicular & $*$ & 0,29 \\
\hline $22 / 06 / 01$ & Folicular & 0,0172 & 0,25 \\
\hline $23 / 06 / 01$ & Folicular & 0,0185 & 0,06 \\
\hline $24 / 06 / 01$ & Folicular & 0,0156 & 0,22 \\
\hline $25 / 06 / 01$ & Folicular & 0,0202 & 0,23 \\
\hline $26 / 06 / 01$ & Luteal & 0,0179 & 0,33 \\
\hline $27 / 06 / 01$ & Luteal & $*$ & 168,69 \\
\hline $28 / 06 / 01$ & Luteal & 0,0240 & 185,32 \\
\hline
\end{tabular}




\begin{tabular}{|c|c|c|c|}
\hline $29 / 06 / 01$ & Luteal & 0,0177 & 186,72 \\
\hline $30 / 06 / 01$ & Luteal & 0,0163 & 183,59 \\
\hline $01 / 07 / 01$ & Luteal & 0,0131 & 183,93 \\
\hline $02 / 07 / 01$ & Luteal & 0,0206 & 180,85 \\
\hline $03 / 07 / 01$ & Luteal & $*$ & 184,97 \\
\hline $04 / 07 / 01$ & Luteal & $*$ & 186,72 \\
\hline $05 / 07 / 01$ & Luteal & $*$ & 186,72 \\
\hline $06 / 07 / 01$ & Luteal & $*$ & 185,32 \\
\hline $07 / 07 / 01$ & Luteal & $*$ & 186,37 \\
\hline $08 / 07 / 01$ & Luteal & 0,0163 & 189,19 \\
\hline $09 / 07 / 01$ & Folicular & 0,0115 & 0,10 \\
\hline
\end{tabular}

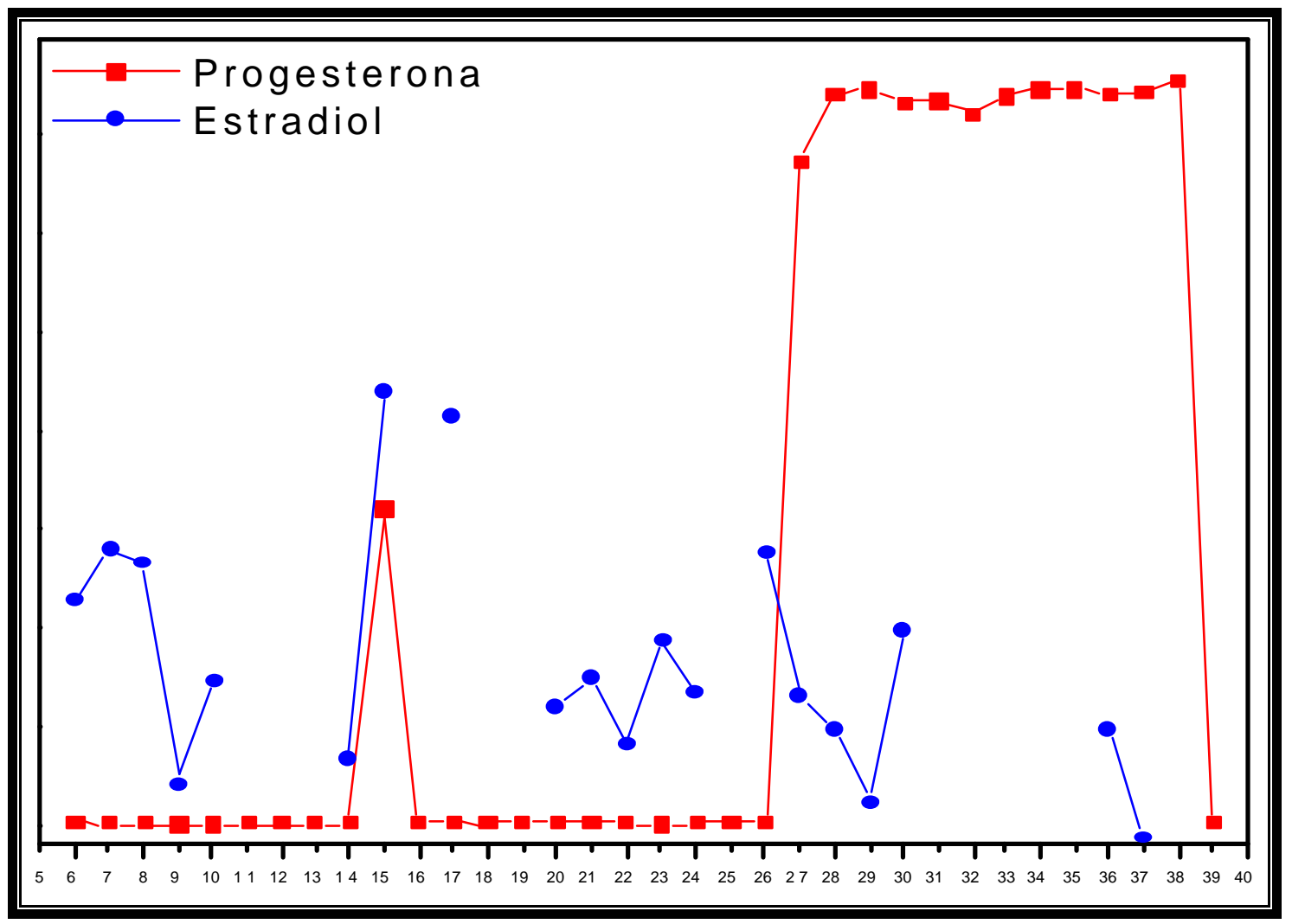

Figura 7.2-1 Representação gráfica dos dados colhidos da dosagem dos hormônios da cabra. Aqui no eixo $\mathrm{X}$ representamos as datas do experimento. No eixo $\mathrm{Y}$ temos os valores da tabela 7.1 $\mathrm{em} \mathrm{Ng/ml}$ 


\section{3-Resultados da Citologia Vaginal.}

O material da citologia, vaginal sofreu dessecamento e não foi possível caracterizar a tipologia celular com as fases do ciclo do animal.

\section{4- Exibição das Mamografias Digitalizadas do Animal.}

Nas figuras a seguir são apresentadas conjuntos de imagens digitalizadas correspondentes a todos os mamogramas da cabra durante o período descrito para uma analise visual da variação dos perfis de densidade radiográfica. Deve se relembrar que todos os parâmetros técnicos de exposição $(\mathrm{kV}, \mathrm{mA}$, tempo, distância, filme, revelação), foram mantidos constantes para todas as tomadas.

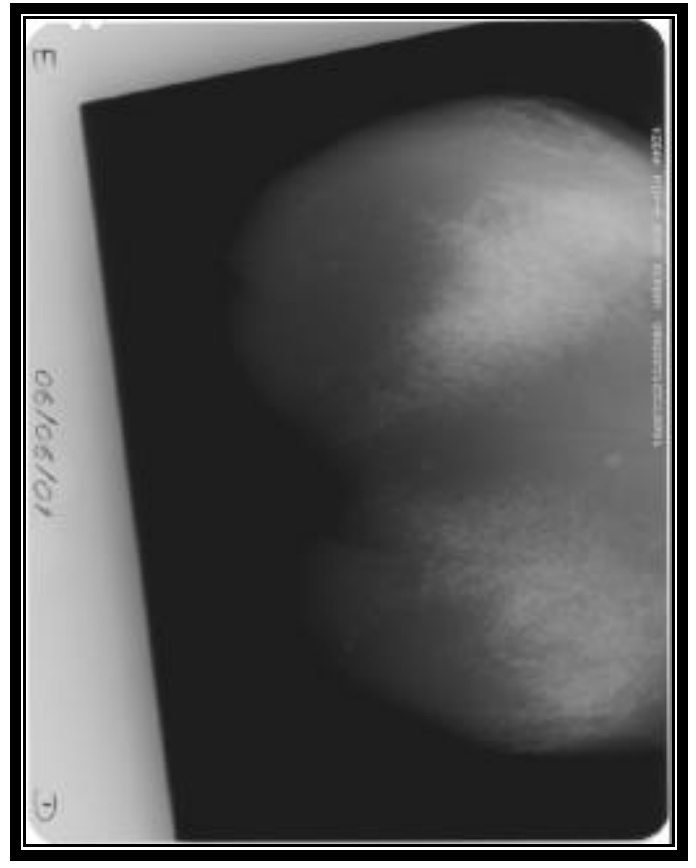

(a)

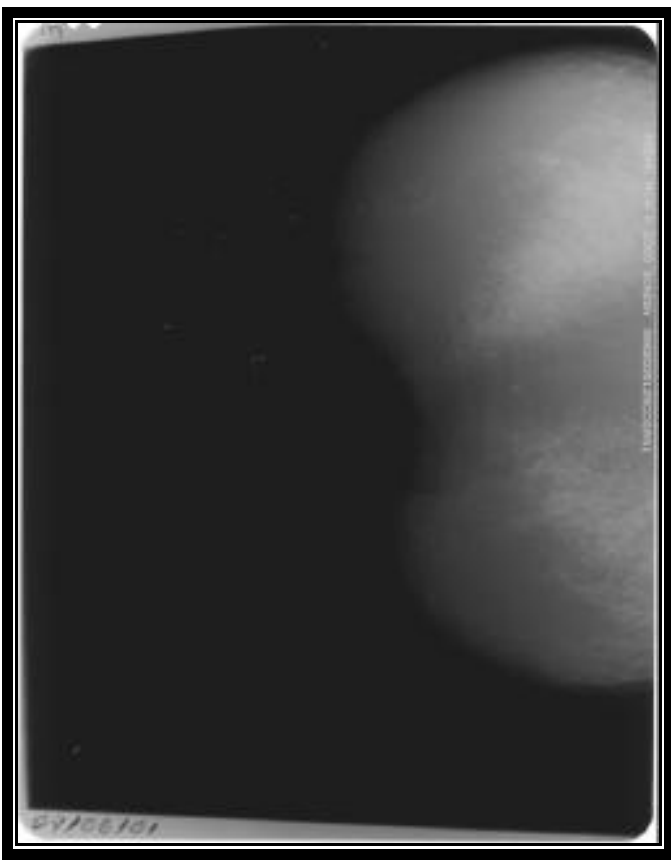

(b) 


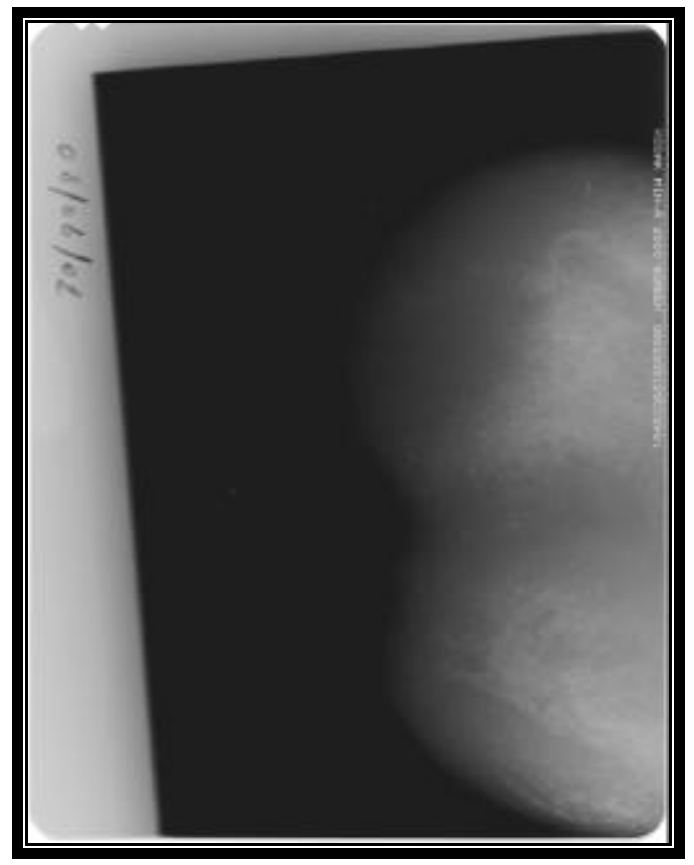

(c)

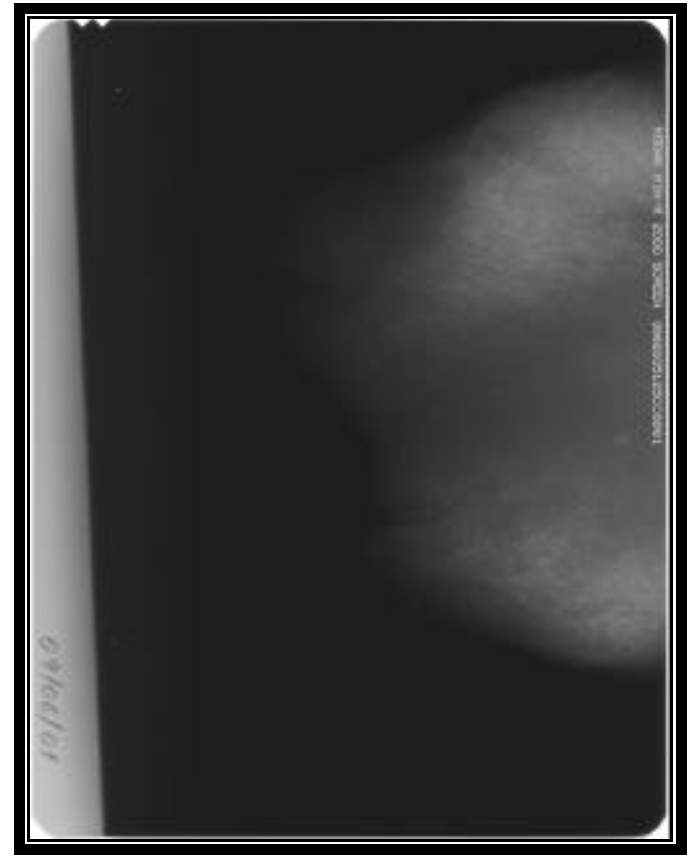

(d)

Figura-7.4-1. Variação da densidade da mama de acordo com as datas: a) 06/06/2001; b) 07/06/2001; c) 08/06/2001; d) 09/06/2001.

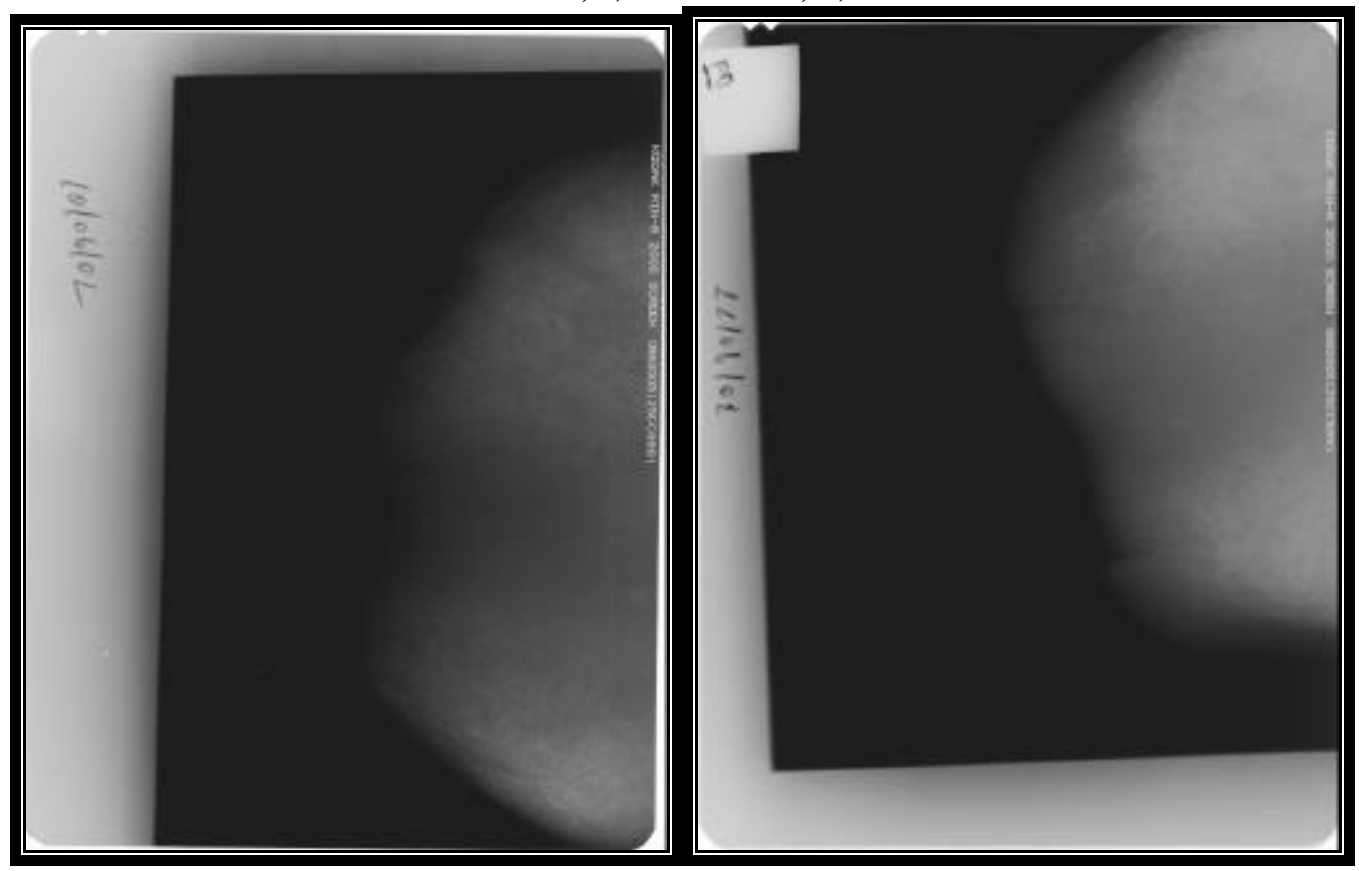

(a)

(b) 


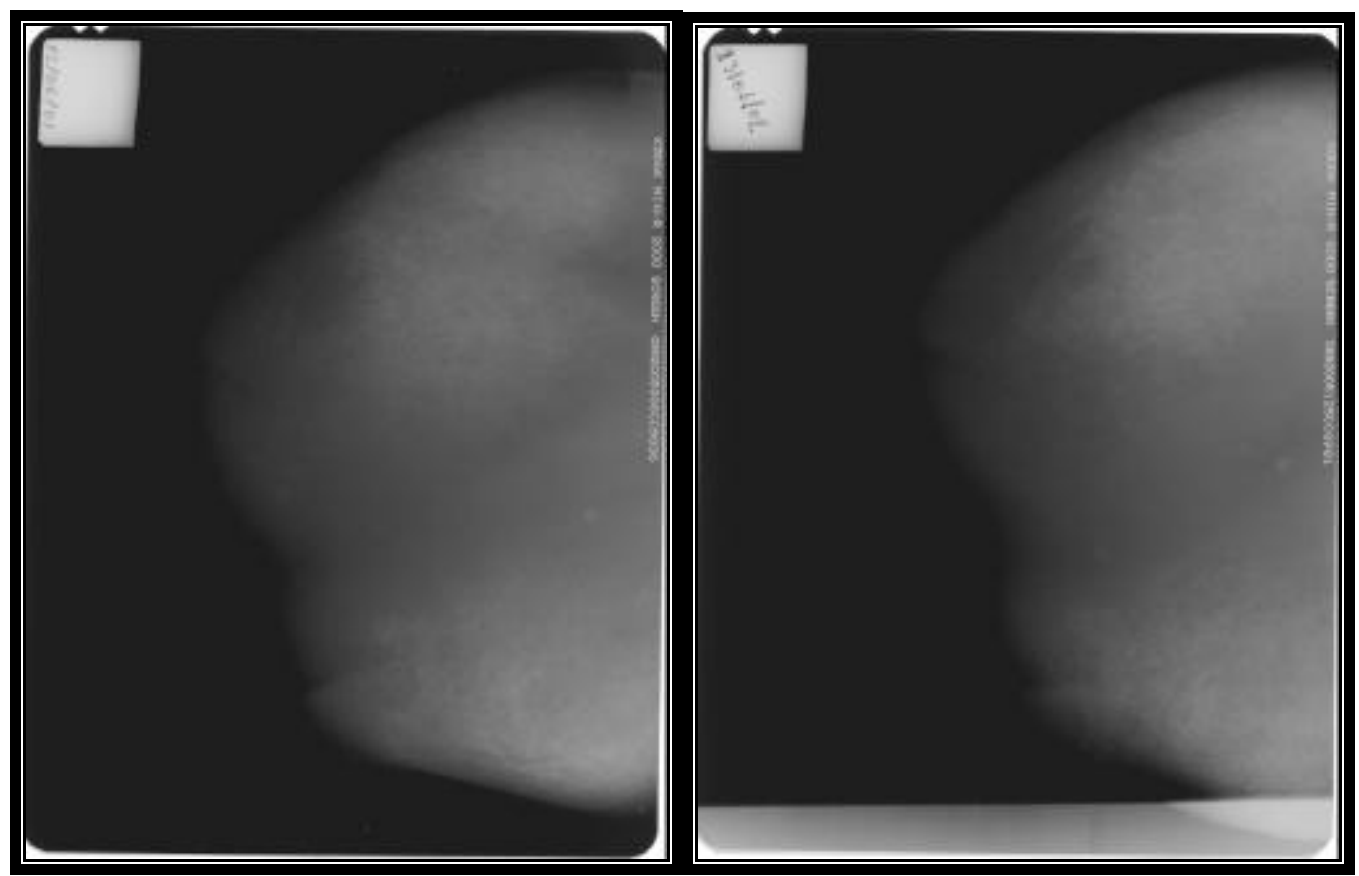

(c)

(d)

Figura-7.4-2. Variação da densidade da mama de acordo com as datas: a) 10/06/2001; b) 11/06/2001; c) 12/06/2001; d) 13/06/2001.

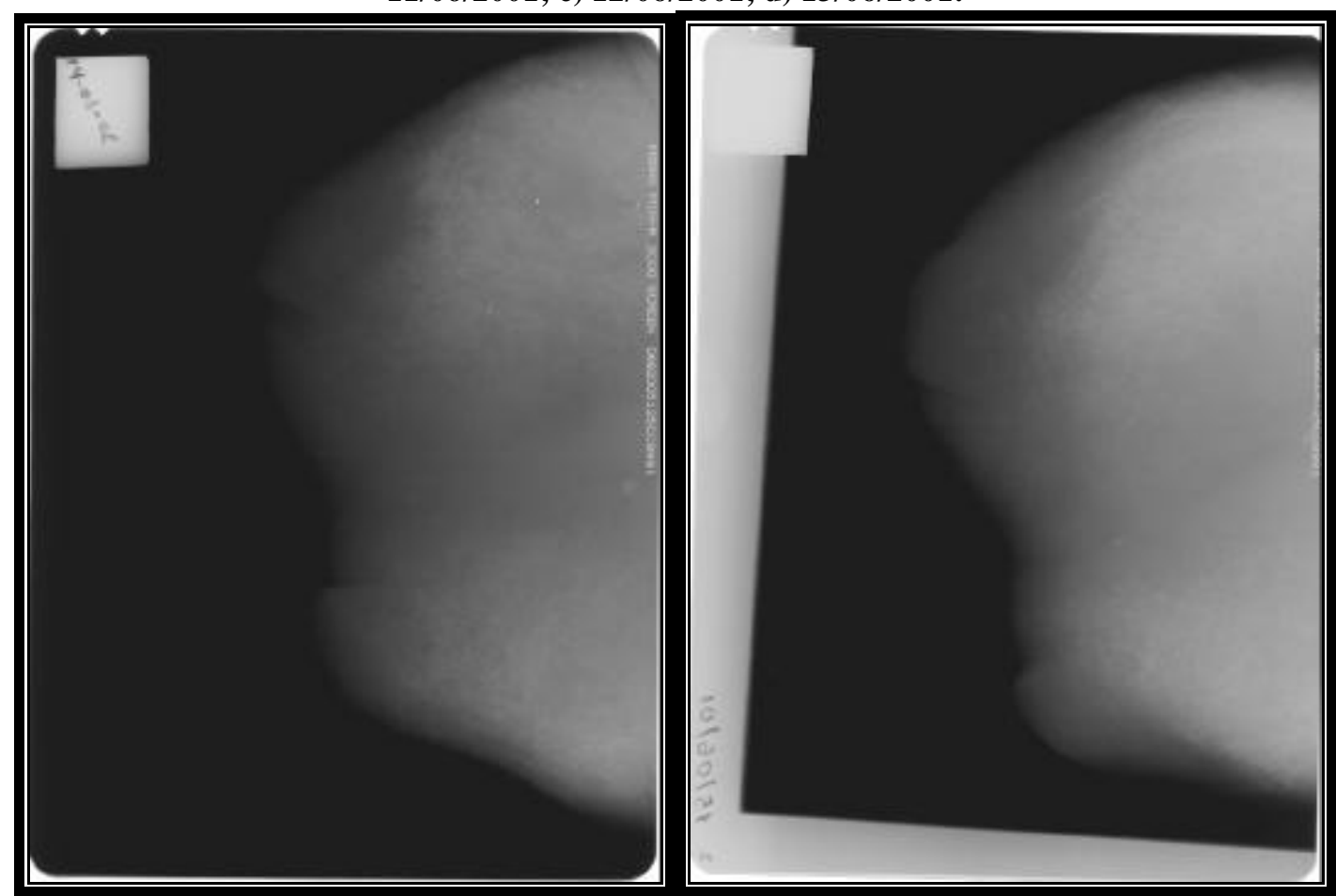

(a)

(b) 


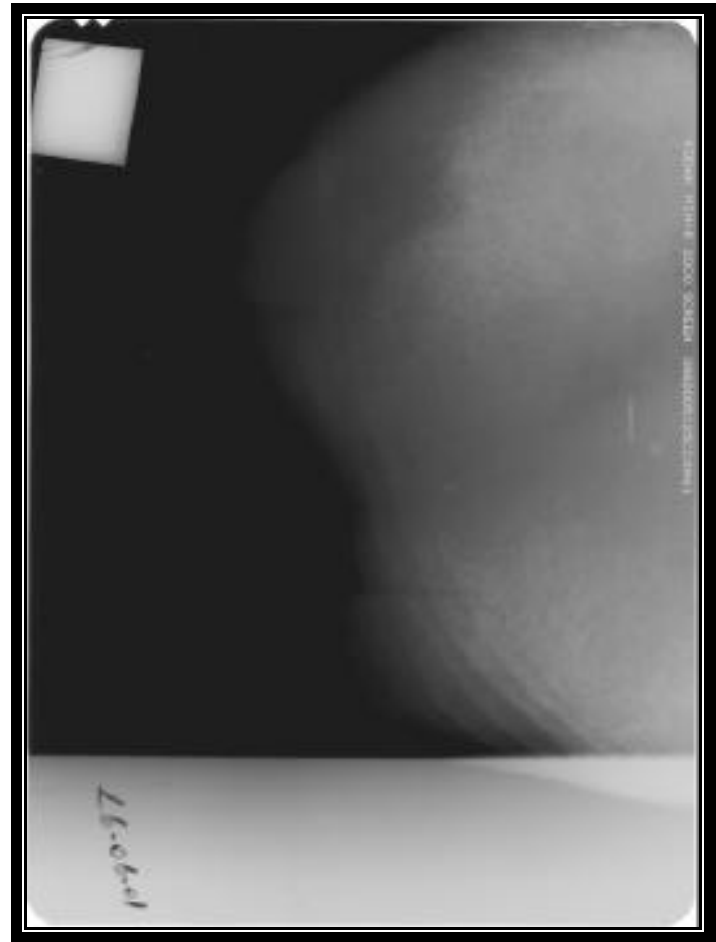

(c)

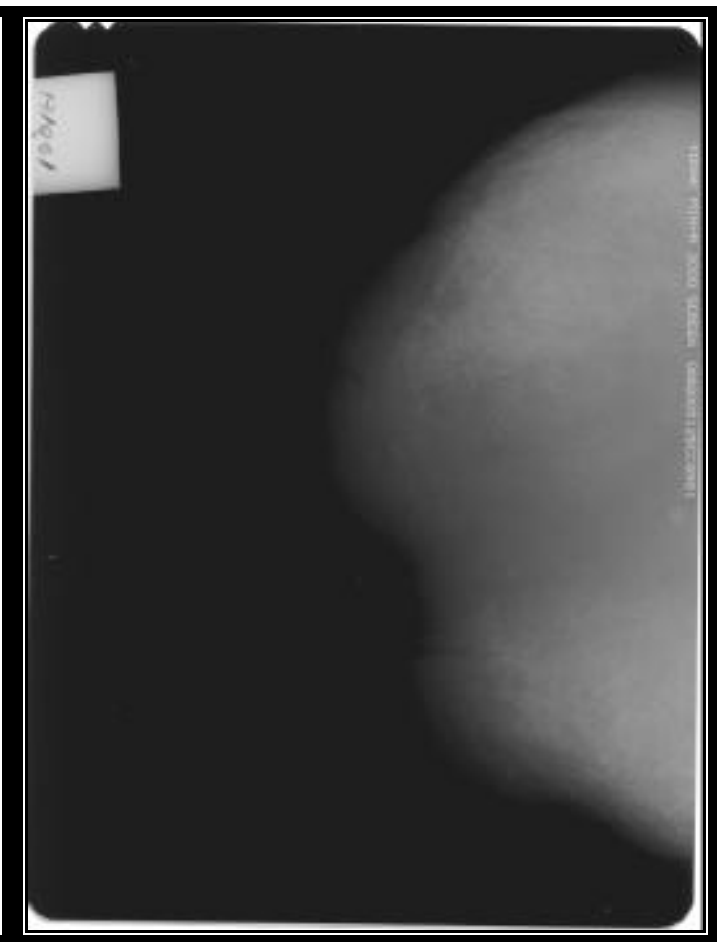

(d)

Figura-7.4-3. Variação da densidade da mama de acordo com as datas: a) 14/06/2001; b) $15 / 06 / 2001$; c) $16 / 06 / 2001$; d) $17 / 06 / 2001$.

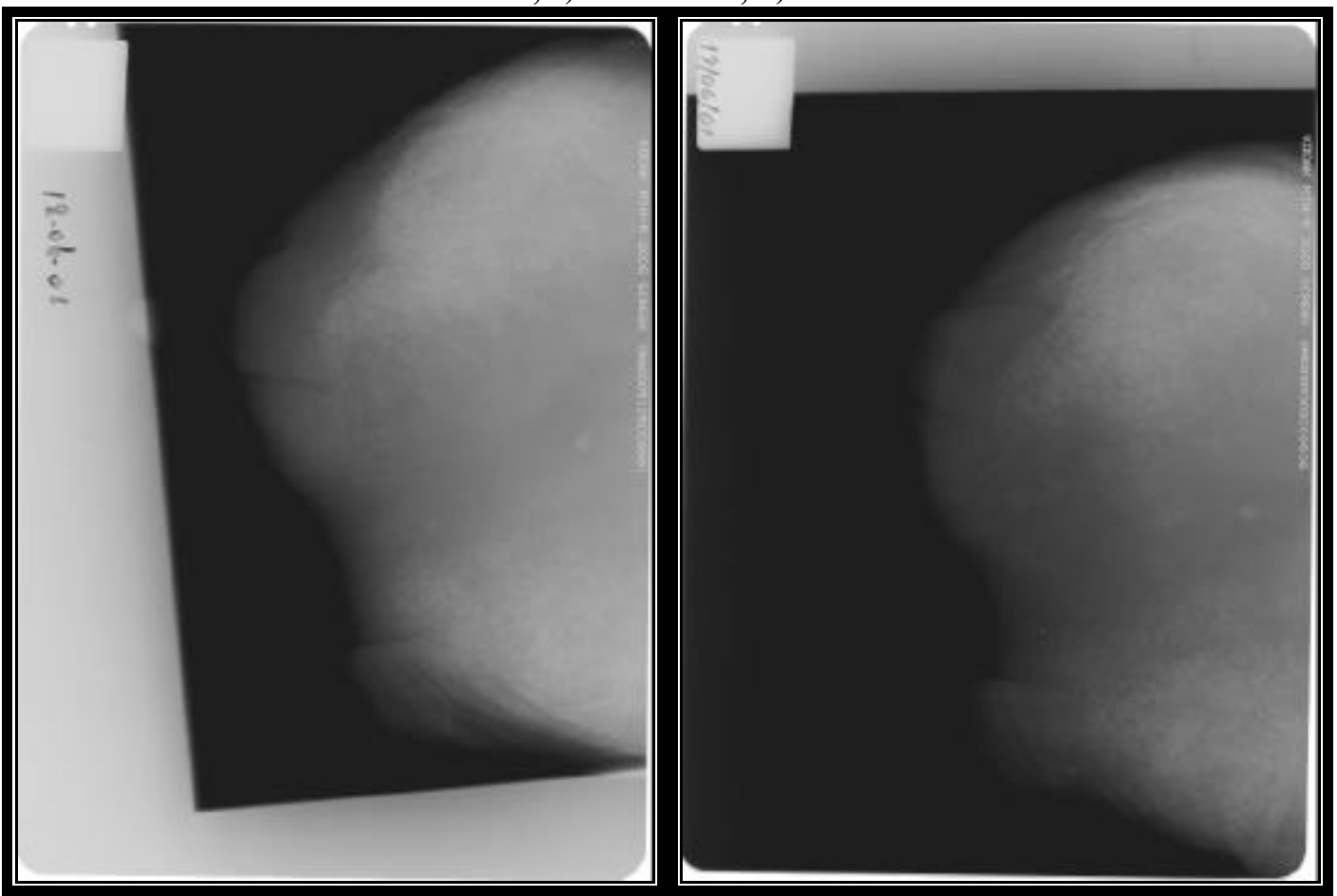

(a)

(b) 


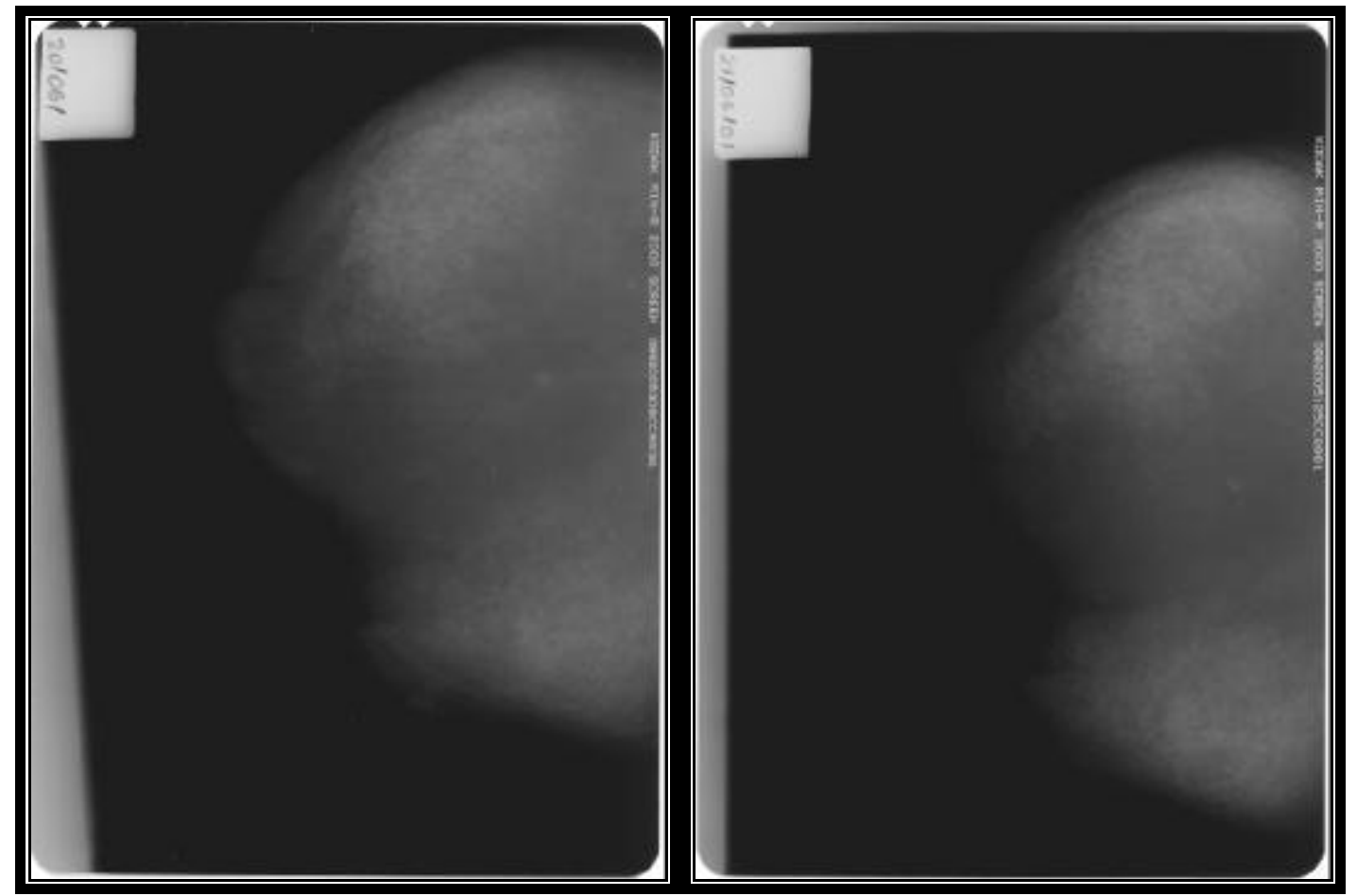

(c)

(d)

Figura-7.4-4. Variação da densidade da mama de acordo com as datas: a) 18/06/2001; b) $19 / 06 / 2001$; c) 20/06/2001; d) 21/06/2001.

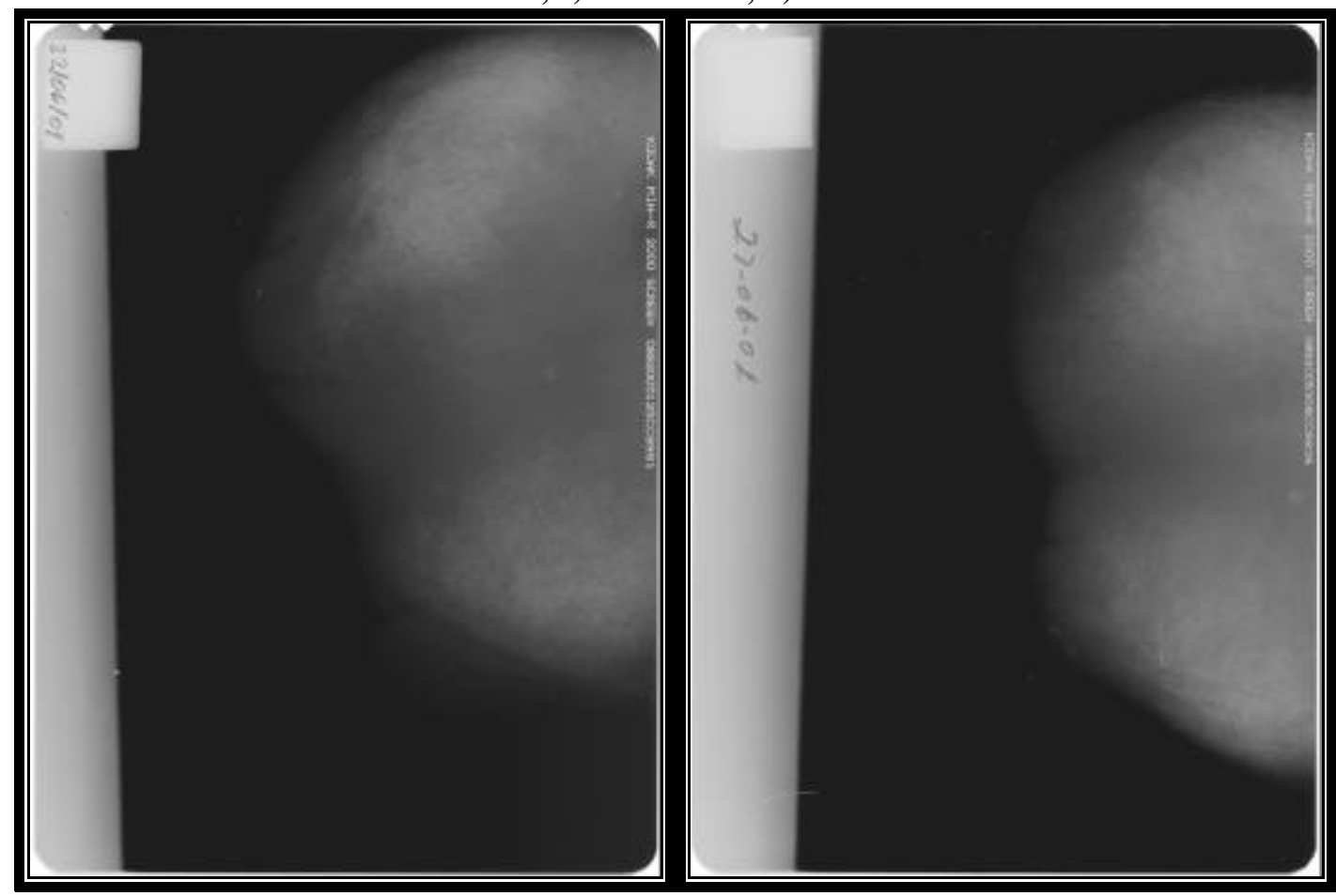

(a)

(b) 


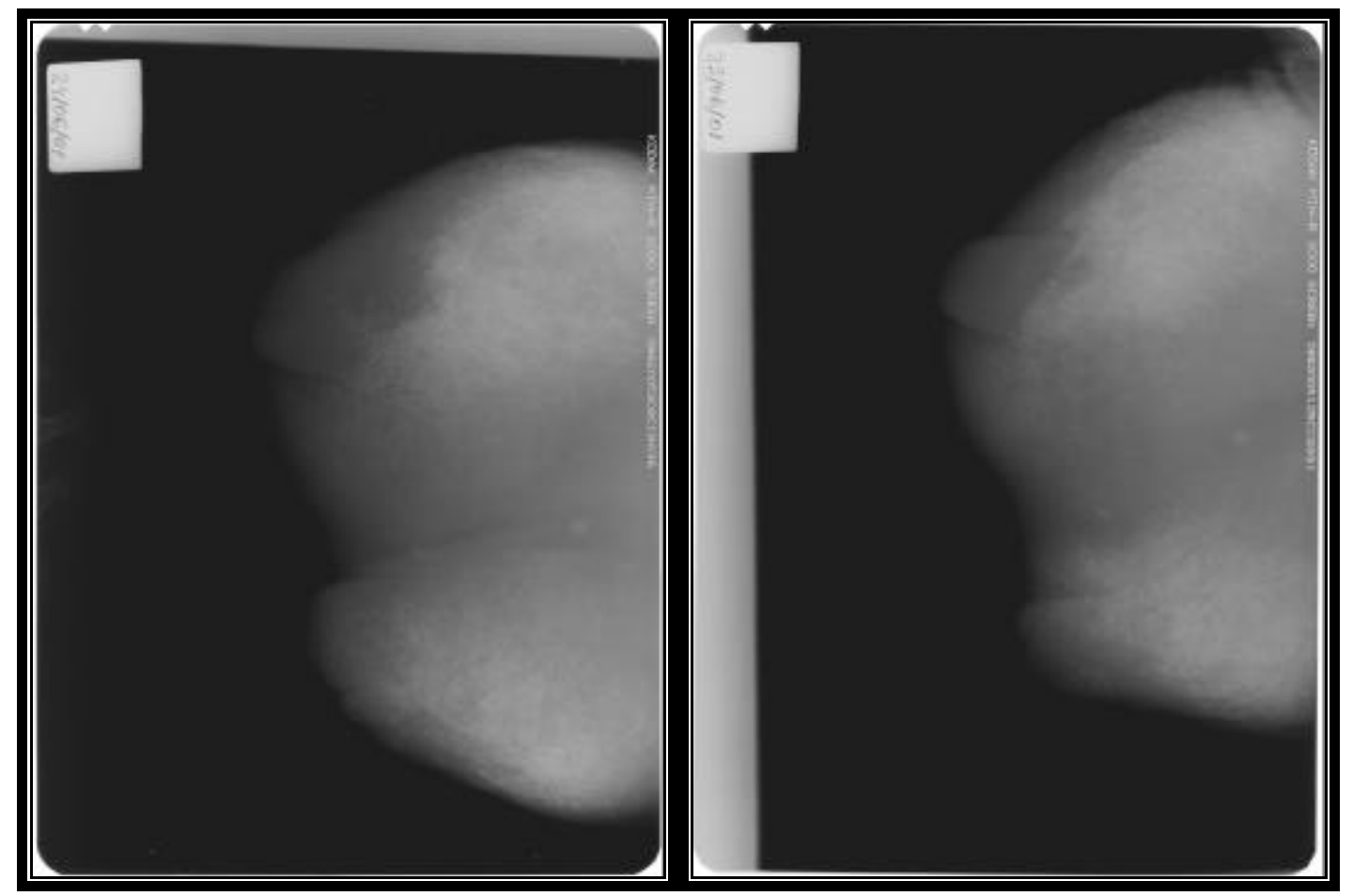

(c)

(d)

Figura-7.4-5. Variação da densidade da mama de acordo com as datas: a) 23/06/2001; b) $24 / 06 / 2001$; c) $25 / 06 / 2001$; d) 26/06/2001.

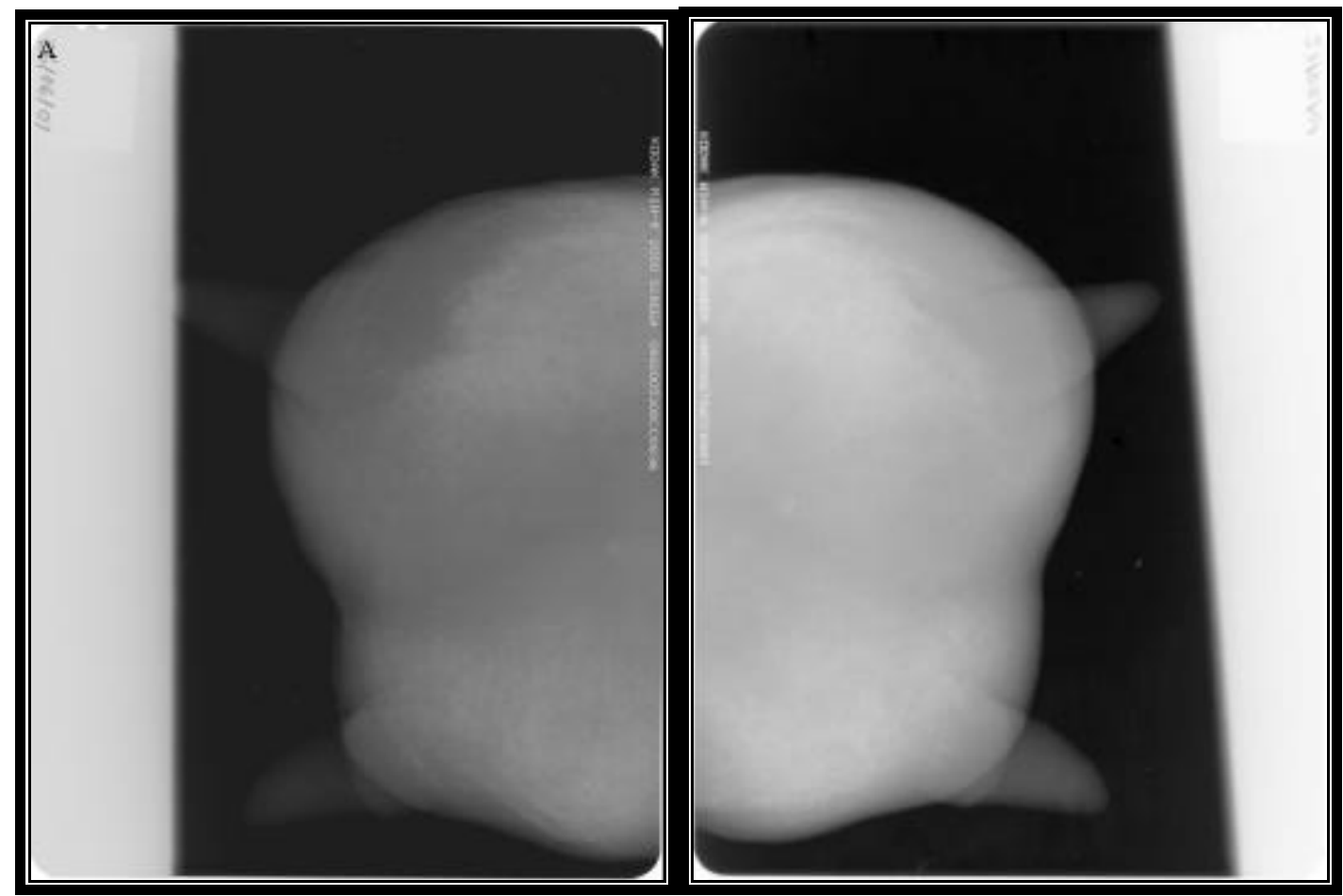

(a)

(b) 


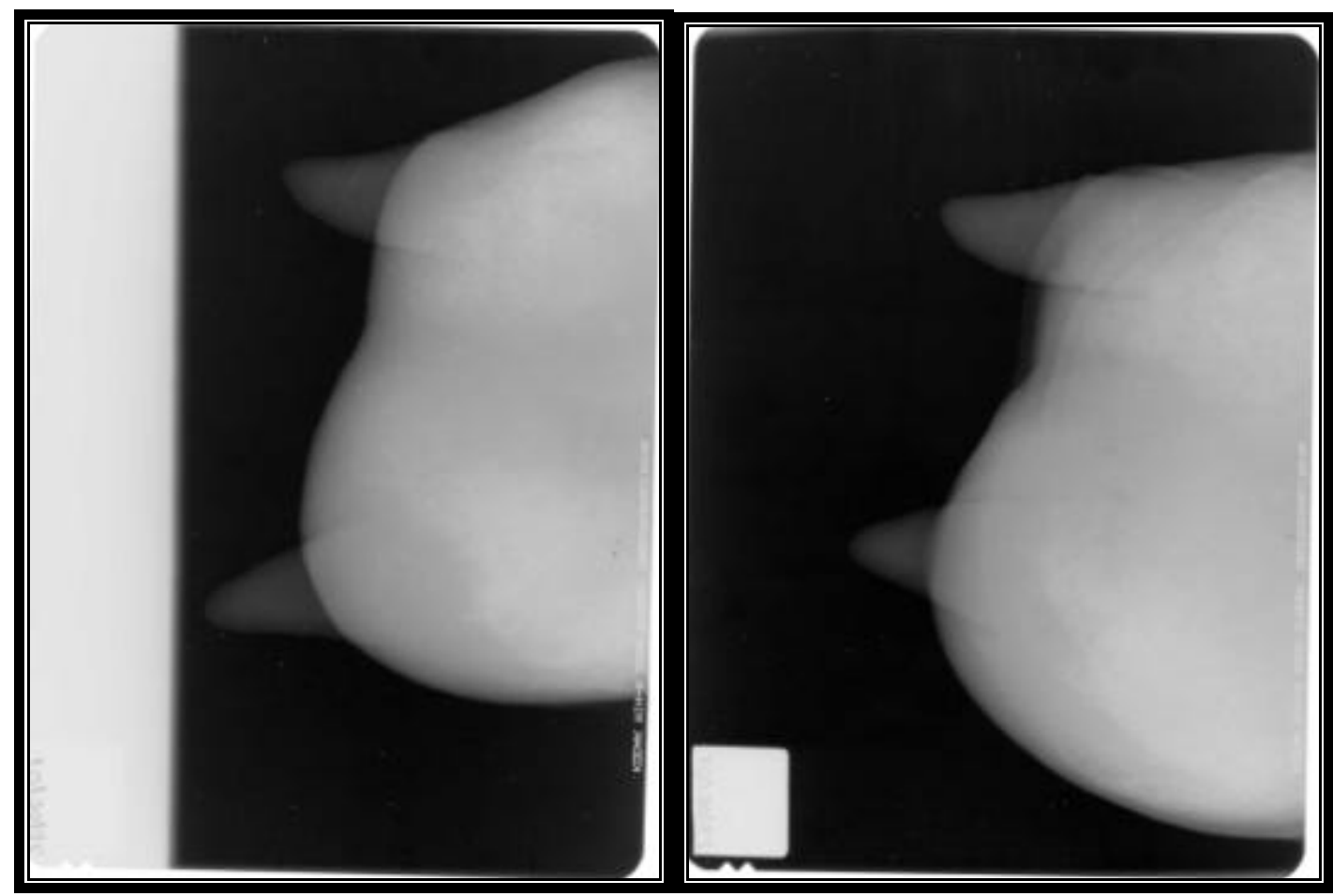

(c)

(d)

Figura-7.4-6 . Variação da densidade da mama de acordo com a data: A) 26/06/01; B) 27/06/01;C) 28/06/01 ; D) 29/06/01

\section{5- Resultado do Histograma do Animal.}

Nas figuras a seguir são apresentadas imagens mamográficas da cabra selecionada dos conjuntos apresentados na seção anterior. Agora estas imagens são retratadas juntamente com seus respectivos histogramas, para uma melhor análise das variações ocorridas no perfil radiográfico, tentando se representar dias estratégicos tal como o dia da ovulação e o dia da fase luteal. 


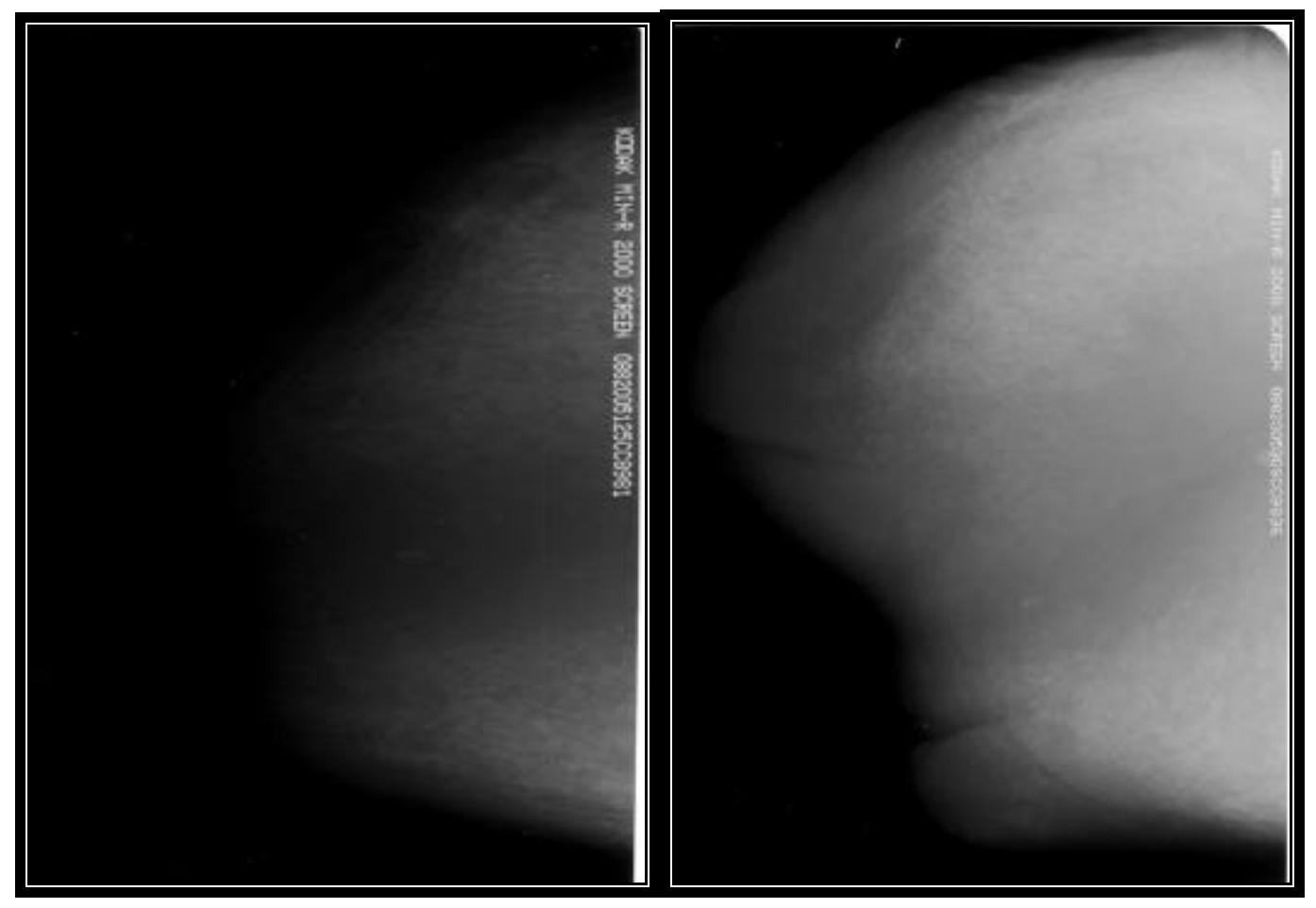

(a)

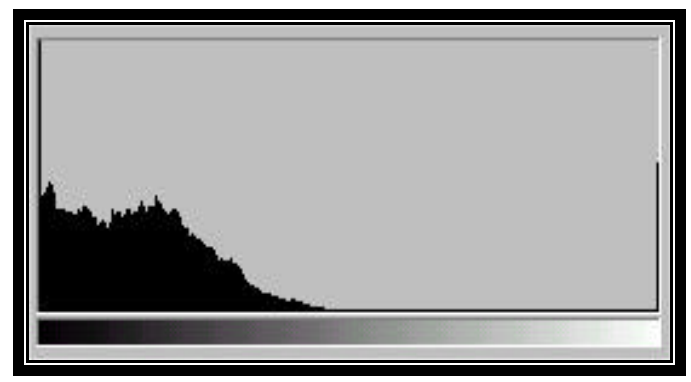

(c) (b)

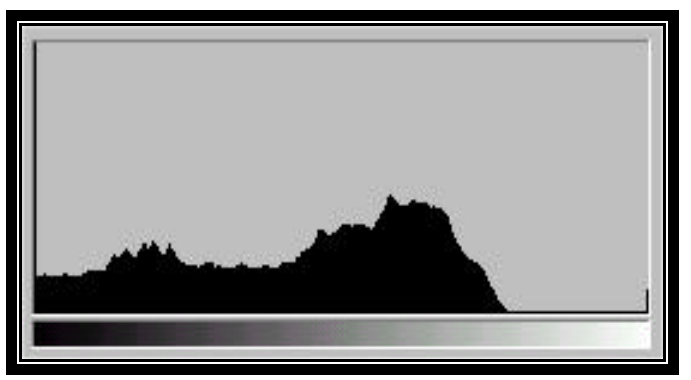

(d)

Figura 7.5-1 Mamografias do animal realizadas nos dias (a) 10/06/01 (b) 15/06/01 e seus respectivos histogramas: (c) Histograma da Imagem a; (d) Histograma da imagem b 


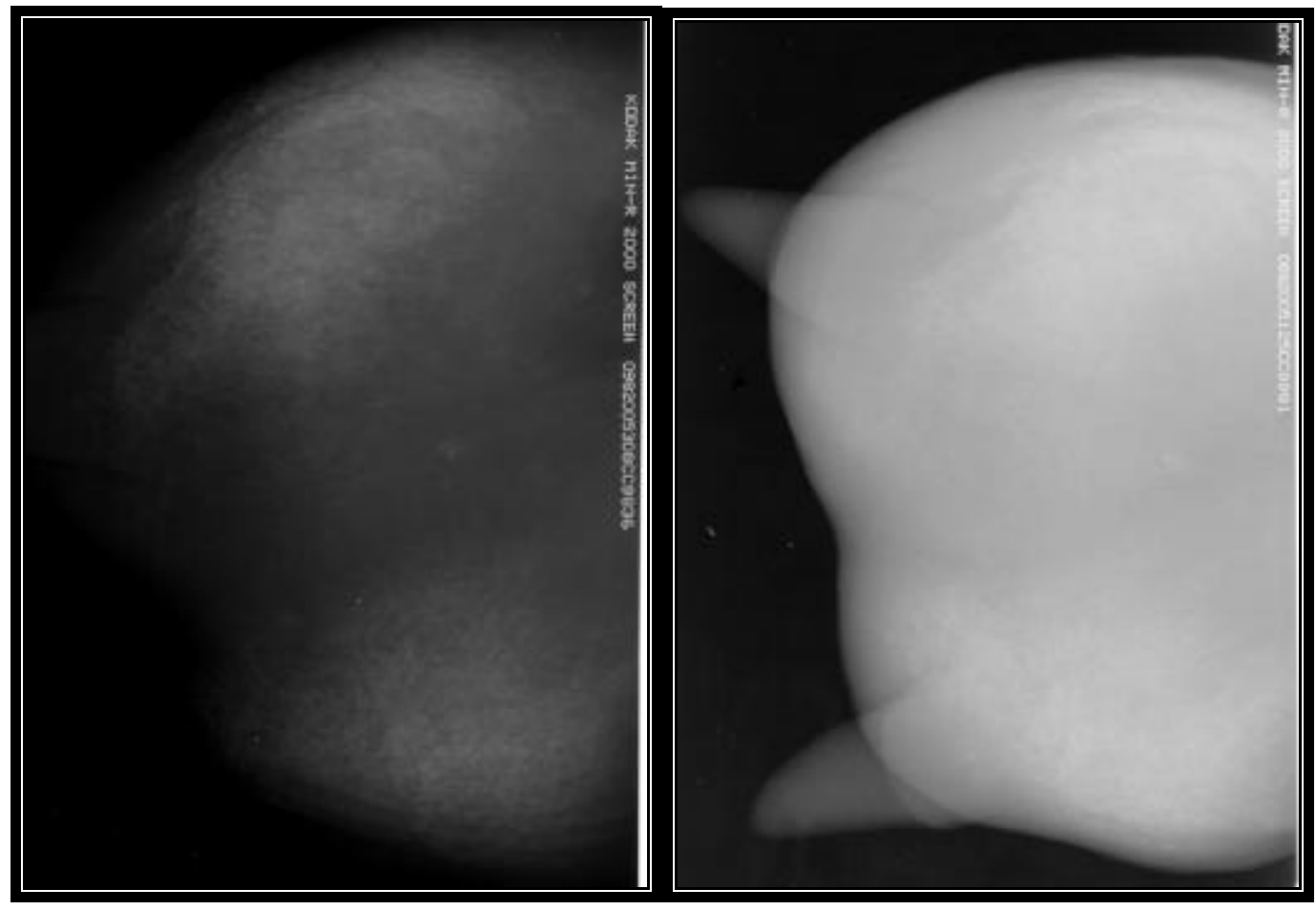

(a)

(b)

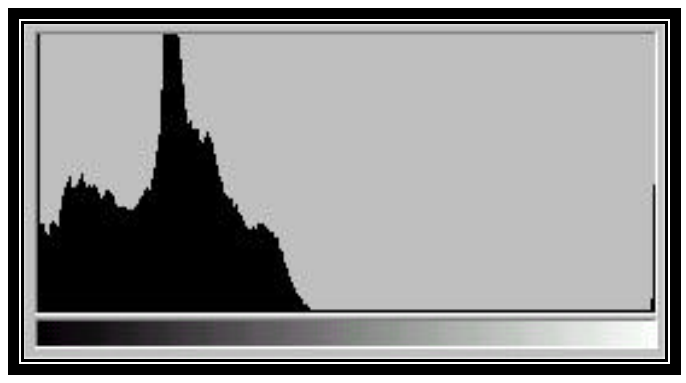

(c)

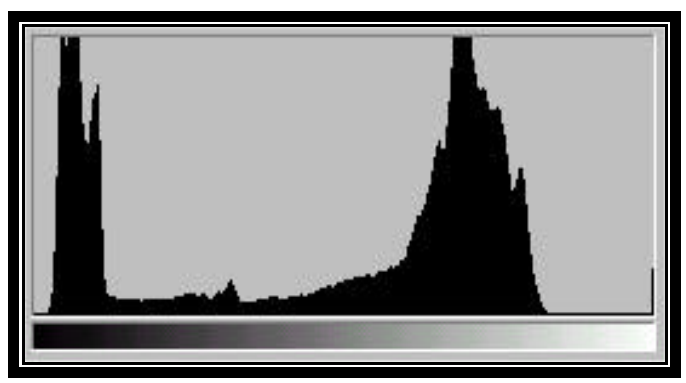

(d)

Figura 7.5-2 Mamografias do animal realizadas nos dias (a) 21/06/01 (b) 26/06/01 e seus respectivos histogramas: (c) Histograma da Imagem a; (d) Histograma da imagem (b) 


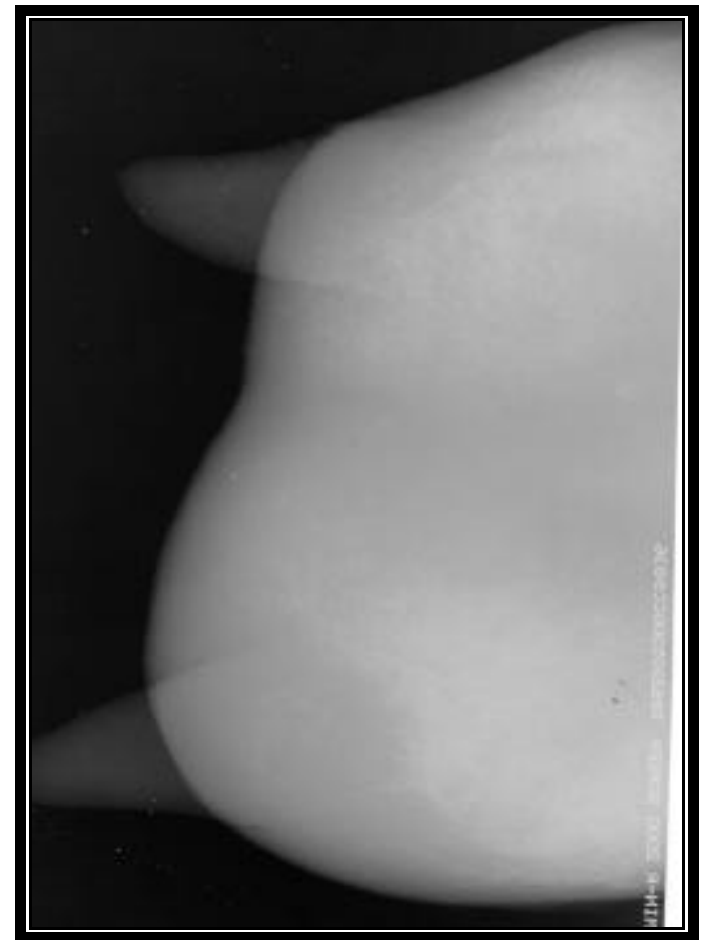

(a)

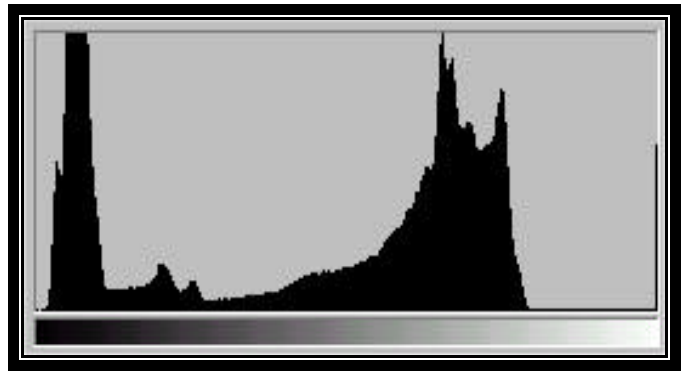

(c)

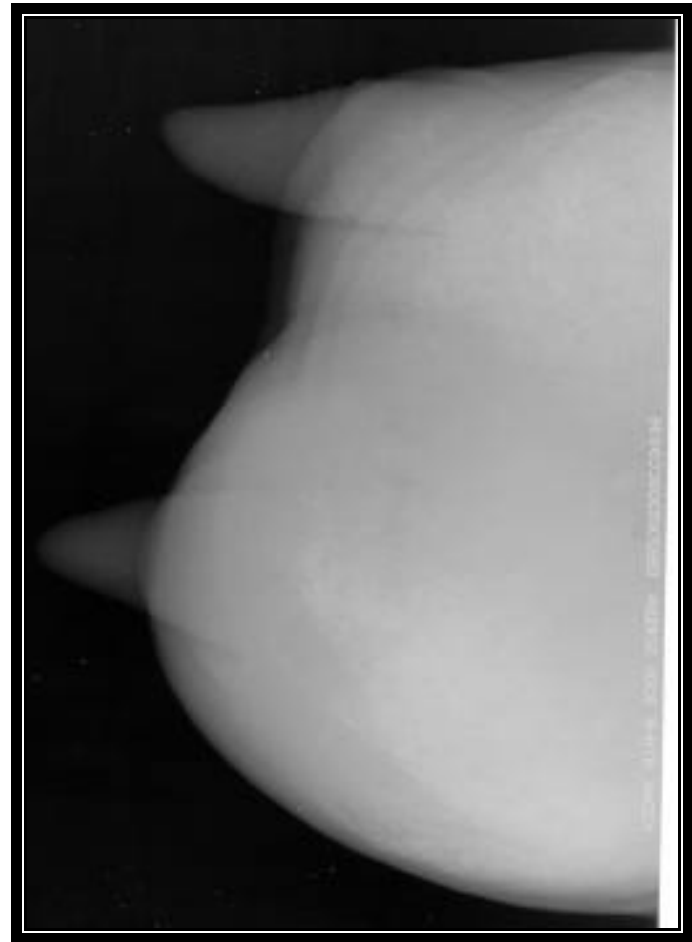

(b)

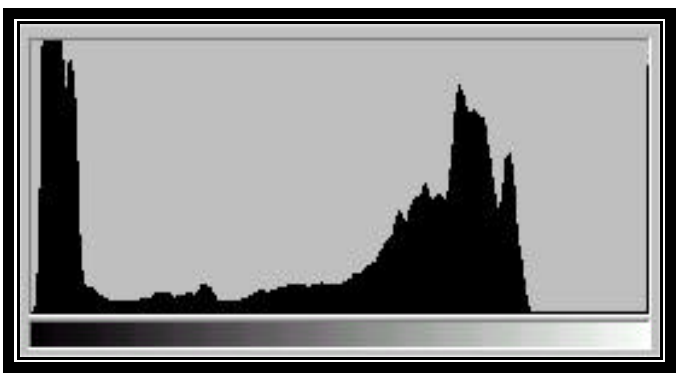

(d)

Figura-7.5-3. Mamografias do animal realizadas nos dias(a) 27/06/01 ; (b) 28/06/01 e seus respectivos histogramas: (c) histograma da imagem (a); (d) histograma da imagem (b)

\section{6-Avaliação Numérica da Variação da Densidade Mamográfica do Animal.}

Neste tópico estão os resultados da avaliação objetiva dos mamogramas do animal. O programa usado tem a capacidade de setorizar a imagem digitalizada da mama e avaliar a densidade em nível de pixel. No nosso experimento, setorizamos cada tomada em 8 setores, e caracterizamos numericamente cada setor assim como a média de todos os setores, ao longo das 24 tomadas. Na figura 7.6-1 estão 
representados por cores diferentes cada setor e sua variação em um gráfico. Chama a atenção o fato de os setores sofrerem variação praticamente uniforme.Na tabela 7.6-1 podemos constatar os valores aferidos em cada setor da imagem digitalizada. $\mathrm{Na}$ figura 7.6-2 podemos ver a média dos valores aferidos de cada setor, o que representa a variação da imagem digitalizada.

Vale salientar que a figura 7.6-2 mostra o ponto mais alto da densidade por volta do dia 26 , que foi quando o animal atingiu a fase luteal. Por outro lado, podemos vislumbrar os dias de menor densidade que são os dias prováveis de ovulação do animal.Podemos ainda verificar que nos dois dias prováveis de ovulação, os níveis de densidade foram próximos, ou seja na escala usada, os dois se situaram entre 0,3 e 0,4 .

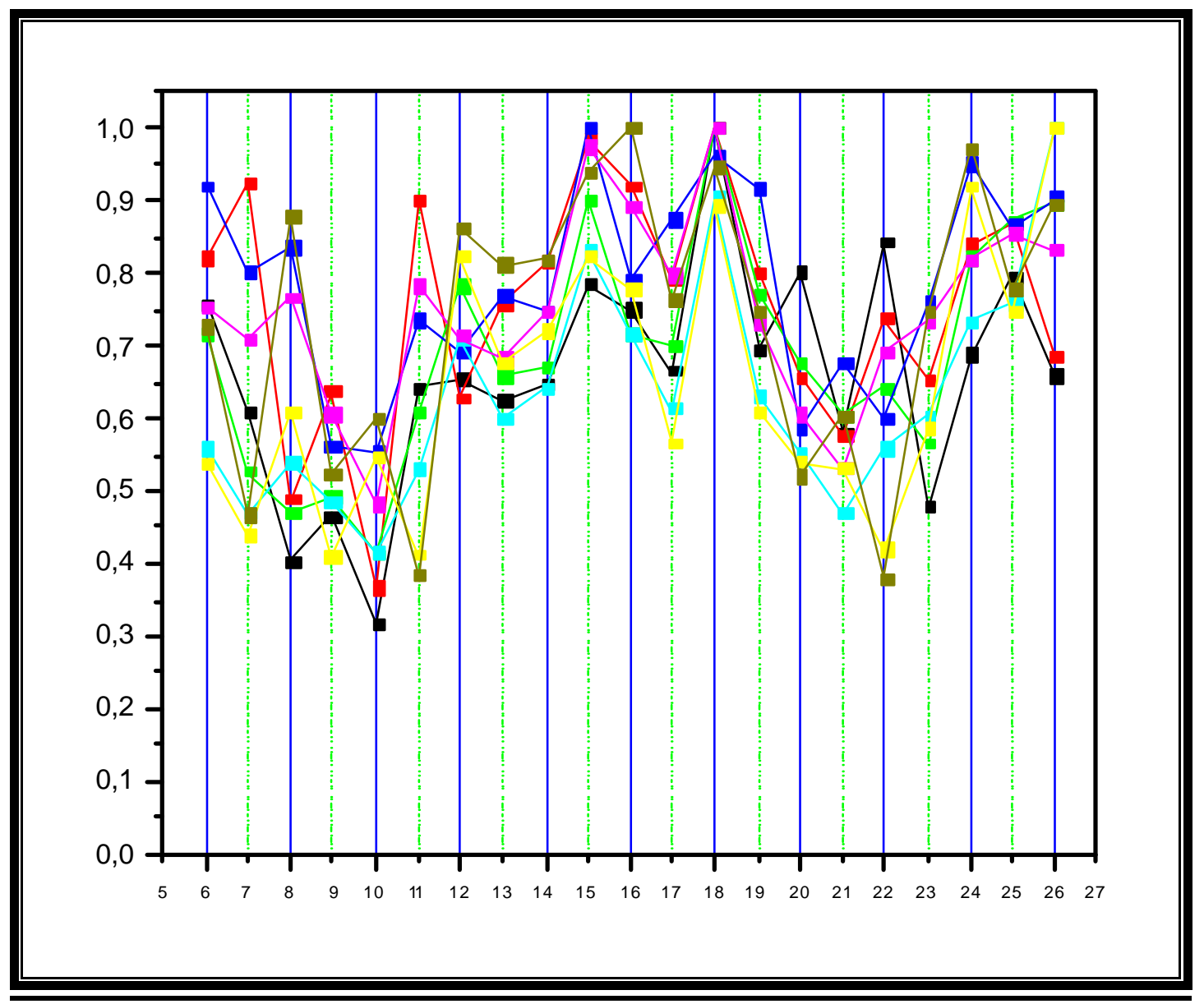

Figura 7.6-1 Grafico representando a variação dos setores da imagem digitalizada do animal. As cores distinguem os setores. No eixo $\mathrm{X}$ representamos os dias de tomadas e no eixo $\mathrm{Y}$ representammos a variação da densidade numa escala de 0-1 
Tabela 7.6-1 - Valores aferidos na avaliação dos tons em cada setor, associados aos dias da tomada.

\begin{tabular}{|cccccccccc|}
\hline DiasCiclo & $\begin{array}{c}\text { Imagem } \\
\text { Inteira }\end{array}$ & Reg1 & Reg2 & Reg3 & Reg4 & Reg5 & Reg6 & Reg7 & Reg8 \\
\hline \hline 6 & 0,58 & 0,76 & 0,82 & 0,72 & 0,92 & 0,56 & 0,75 & 0,54 & 0,73 \\
7 & 0,60 & 0,61 & 0,92 & 0,53 & 0,80 & 0,47 & 0,71 & 0,44 & 0,47 \\
8 & 0,52 & 0,40 & 0,49 & 0,47 & 0,84 & 0,54 & 0,77 & 0,61 & 0,88 \\
9 & 0,51 & 0,46 & 0,64 & 0,49 & 0,56 & 0,48 & 0,61 & 0,41 & 0,52 \\
10 & 0,45 & 0,32 & 0,37 & 0,41 & 0,55 & 0,41 & 0,48 & 0,55 & 0,60 \\
11 & 0,66 & 0,64 & 0,90 & 0,61 & 0,73 & 0,53 & 0,78 & 0,41 & 0,38 \\
12 & 0,56 & 0,65 & 0,63 & 0,78 & 0,69 & 0,71 & 0,71 & 0,82 & 0,86 \\
13 & 0,62 & 0,63 & 0,76 & 0,66 & 0,77 & 0,60 & 0,68 & 0,68 & 0,81 \\
14 & 0,60 & 0,65 & 0,82 & 0,67 & 0,75 & 0,64 & 0,75 & 0,72 & 0,82 \\
15 & 0,71 & 0,78 & 0,98 & 0,90 & 1,00 & 0,83 & 0,97 & 0,82 & 0,94 \\
16 & 0,68 & 0,75 & 0,92 & 0,72 & 0,79 & 0,72 & 0,89 & 0,78 & 1,00 \\
17 & 0,62 & 0,66 & 0,79 & 0,70 & 0,87 & 0,61 & 0,80 & 0,57 & 0,76 \\
18 & 0,76 & 1,00 & 1,00 & 1,00 & 0,96 & 0,90 & 1,00 & 0,89 & 0,95 \\
19 & 0,60 & 0,69 & 0,80 & 0,77 & 0,92 & 0,63 & 0,73 & 0,61 & 0,75 \\
20 & 0,50 & 0,80 & 0,66 & 0,68 & 0,59 & 0,55 & 0,61 & 0,54 & 0,52 \\
21 & 0,51 & 0,58 & 0,58 & 0,60 & 0,68 & 0,47 & 0,53 & 0,53 & 0,60 \\
22 & 0,48 & 0,84 & 0,74 & 0,64 & 0,60 & 0,56 & 0,69 & 0,42 & 0,38 \\
23 & 0,60 & 0,48 & 0,65 & 0,56 & 0,76 & 0,60 & 0,73 & 0,59 & 0,75 \\
24 & 0,71 & 0,69 & 0,84 & 0,82 & 0,95 & 0,73 & 0,82 & 0,92 & 0,97 \\
25 & 0,69 & 0,80 & 0,87 & 0,87 & 0,86 & 0,76 & 0,85 & 0,75 & 0,78 \\
26 & 0,77 & 0,66 & 0,68 & 0,89 & 0,90 & 1,00 & 0,83 & 1,00 & 0,89 \\
27 & 1,00 & 0,86 & 0,89 & 1,00 & 1,00 & 1,00 & 1,00 & 1,00 & 1,00 \\
28 & 0,88 & 0,75 & 0,78 & 1,00 & 1,00 & 1,00 & 0,95 & 1,00 & 1,00 \\
29 & 0,88 & 0,75 & 0,78 & 1,00 & 1,00 & 1,00 & 0,95 & 1,00 & 1,00 \\
\hline
\end{tabular}




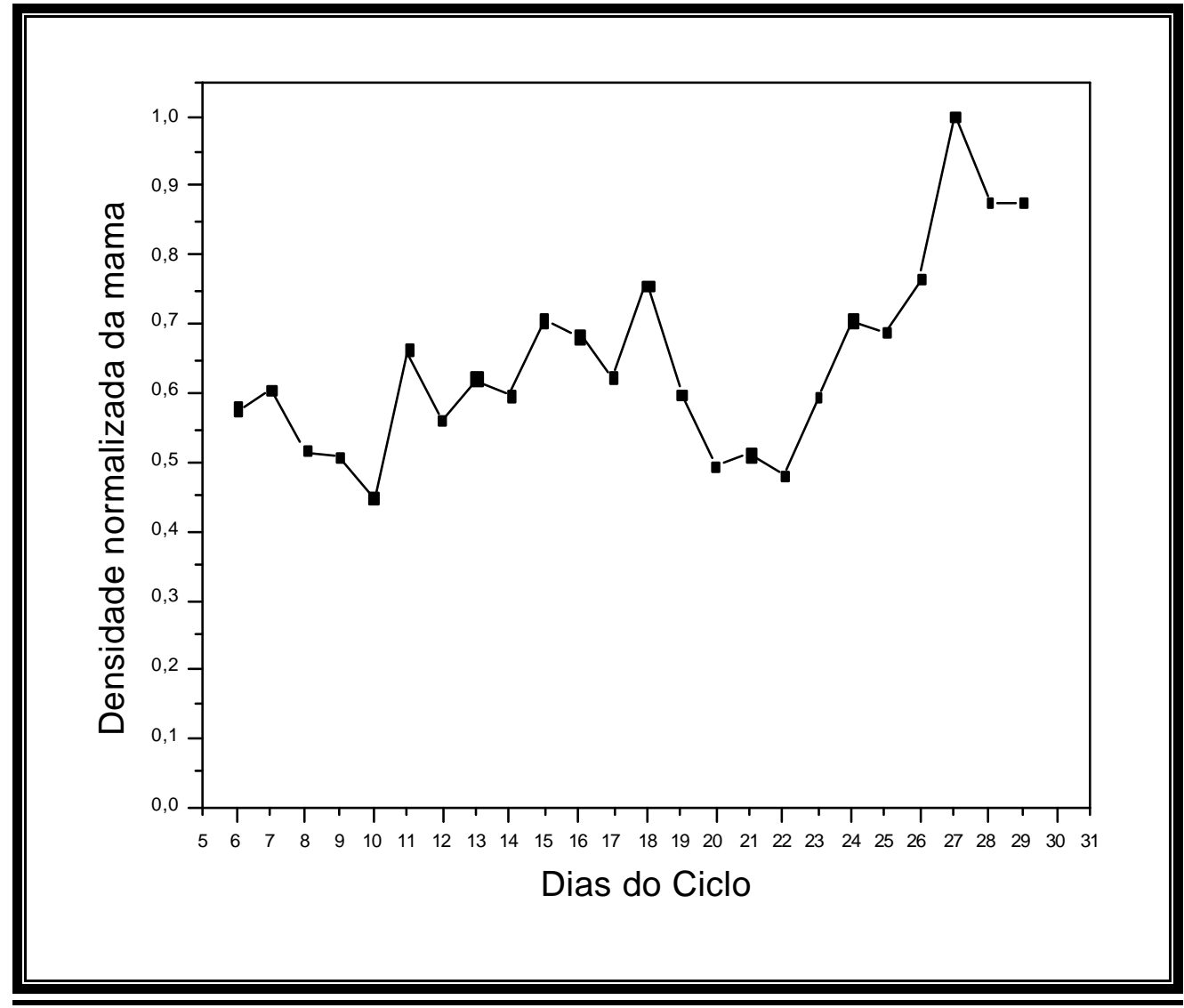

Figura 7.6-2 . Variação media calculada a partir da media dos valores aferidos em cada setor. No eixo $X$ representamos as datas das tomadas e no eixo $Y$ a variação escalar de 0-1.

\section{7- Exibição das Mamografias Digitalizadas Femininas.}

Conforme previamente comentado no capítulo anterior os resultados da avaliação das imagens radiográficas da cabra levaram à pesquisa e seleção de um conjunto de 11 casos de mulheres que haviam coincidentemente feito exames mamográficos nas fases periovulatória e fase luteal de um mesmo ciclo menstrual.As figuras a seguir, portanto, mostram pares de mamogramas da mesma mama de cada uma dessas mulheres, com a finalidade de estabelecer uma comparação da nitidez entre elas nas duas fases do ciclo. Vale salientar que um dos critérios de seleção das mamografias femininas era a manutenção da técnica, isto é somente selecionamos os casos em que a técnica da primeira tomada foi idêntica à técnica da segunda tomada. 


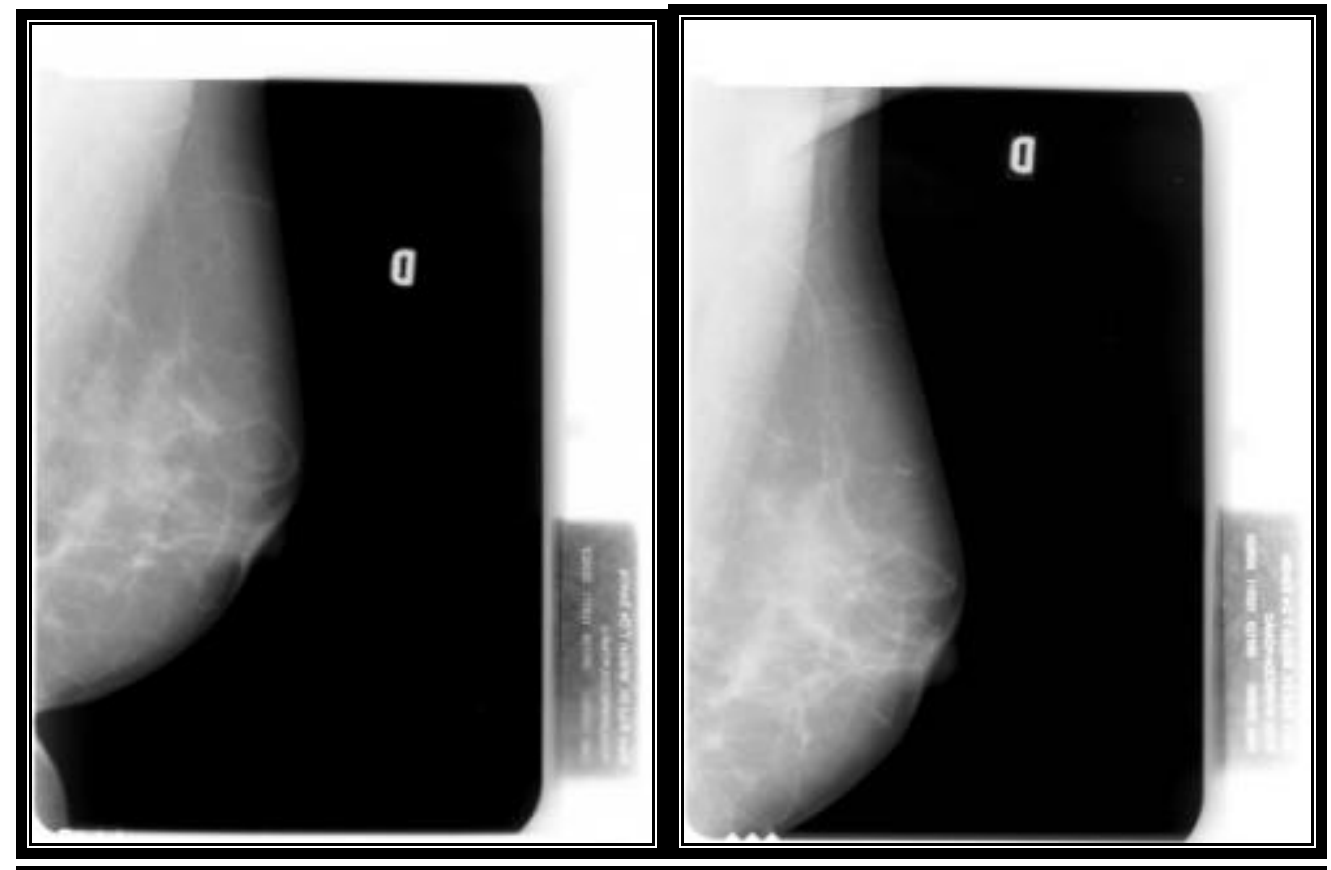

(a)

(b)

Figura 7.7-1 Exibição de dois mamogramas de uma das onze mulheres com a mesma técnica, sendo (a) Fase periovulatória;(b) Fase luteal, do mesmo ciclo.

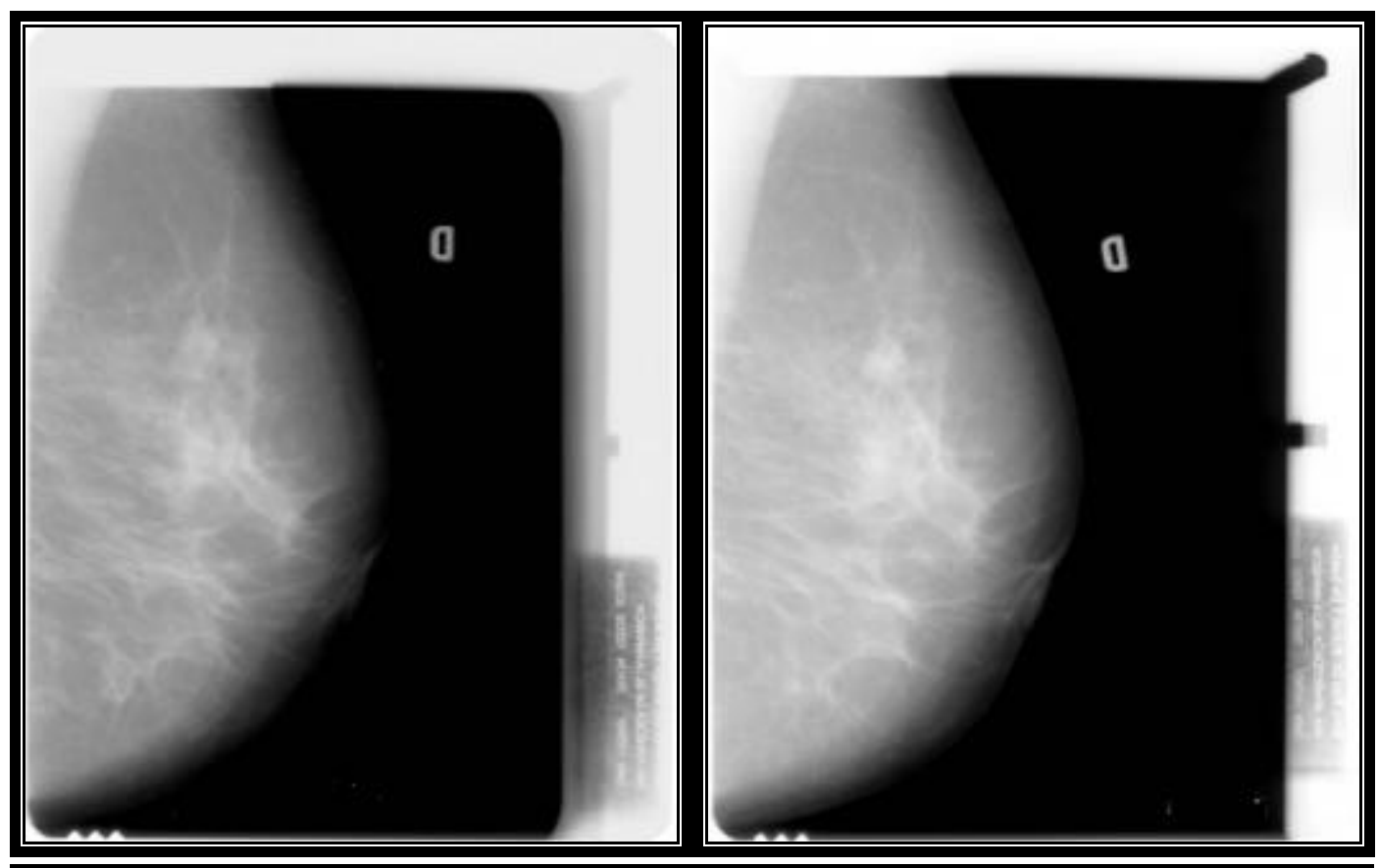

(a)

(b)

Figura 7.7-2 Exibição de dois mamogramas de uma das onze mulheres com a mesma técnica , sendo (a) Fase periovulatória;(b) Fase luteal, do mesmo ciclo. 


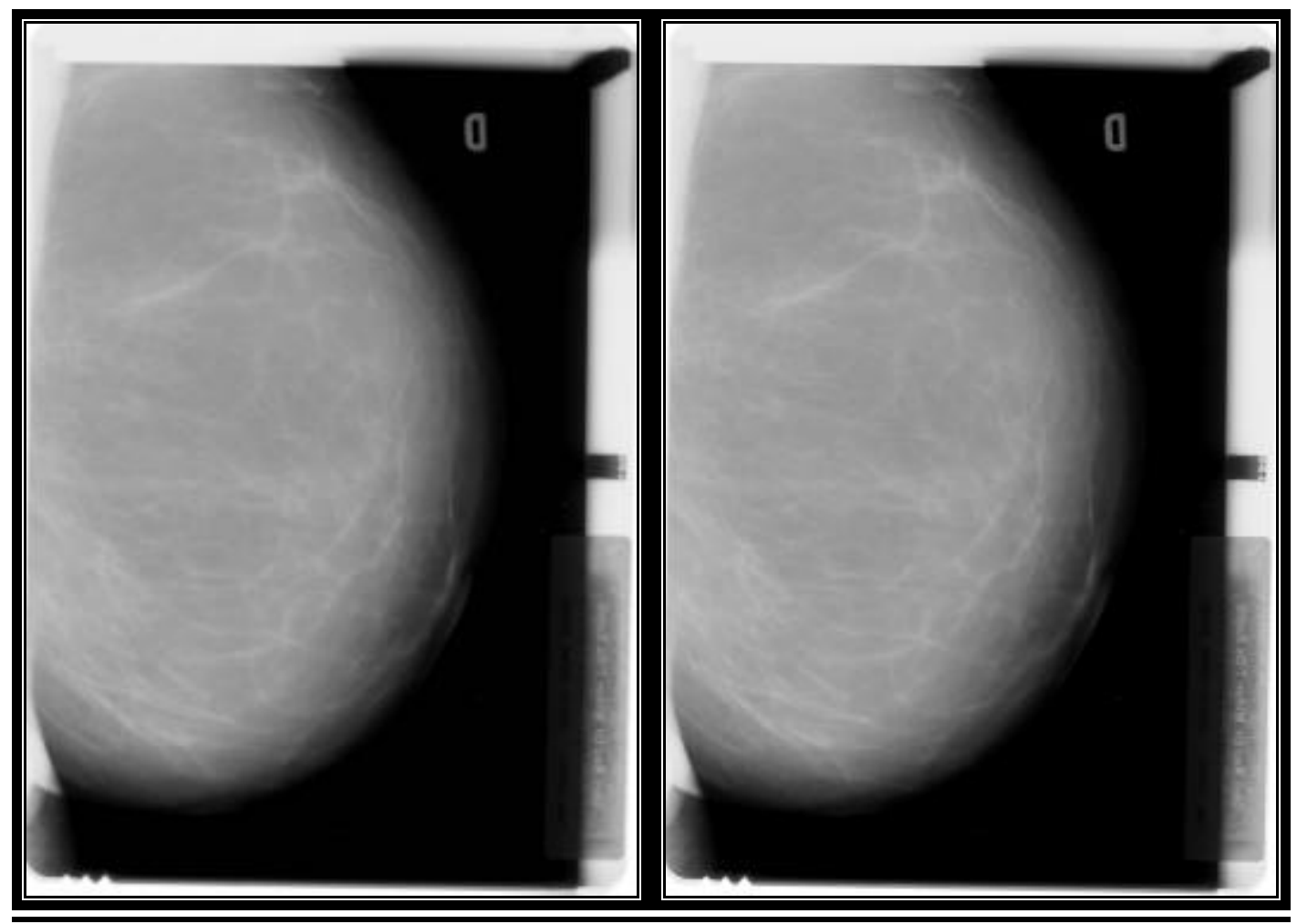

(a)

(b)

Figura 7.7-3 Exibição de dois mamogramas de uma das onze mulheres com a mesma técnica, sendo (a) Fase periovulatória;(b) Fase luteal , do mesmo ciclo. 


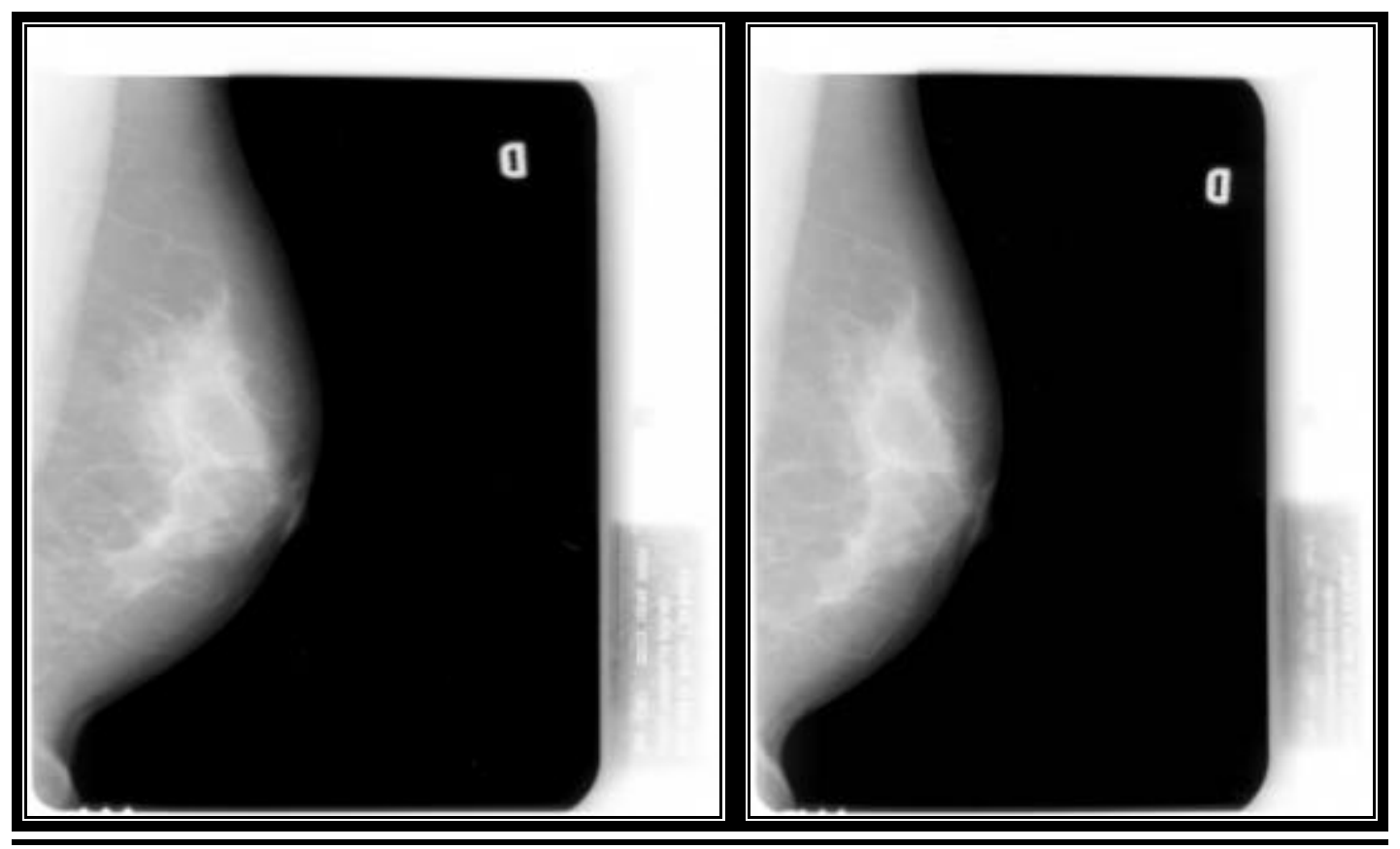

(a)

(b)

Figura 7.7-4 Exibição de dois mamogramas de uma das onze mulheres com a mesma técnica , sendo (a) Fase periovulatória;(b) Fase luteal , do mesmo ciclo.

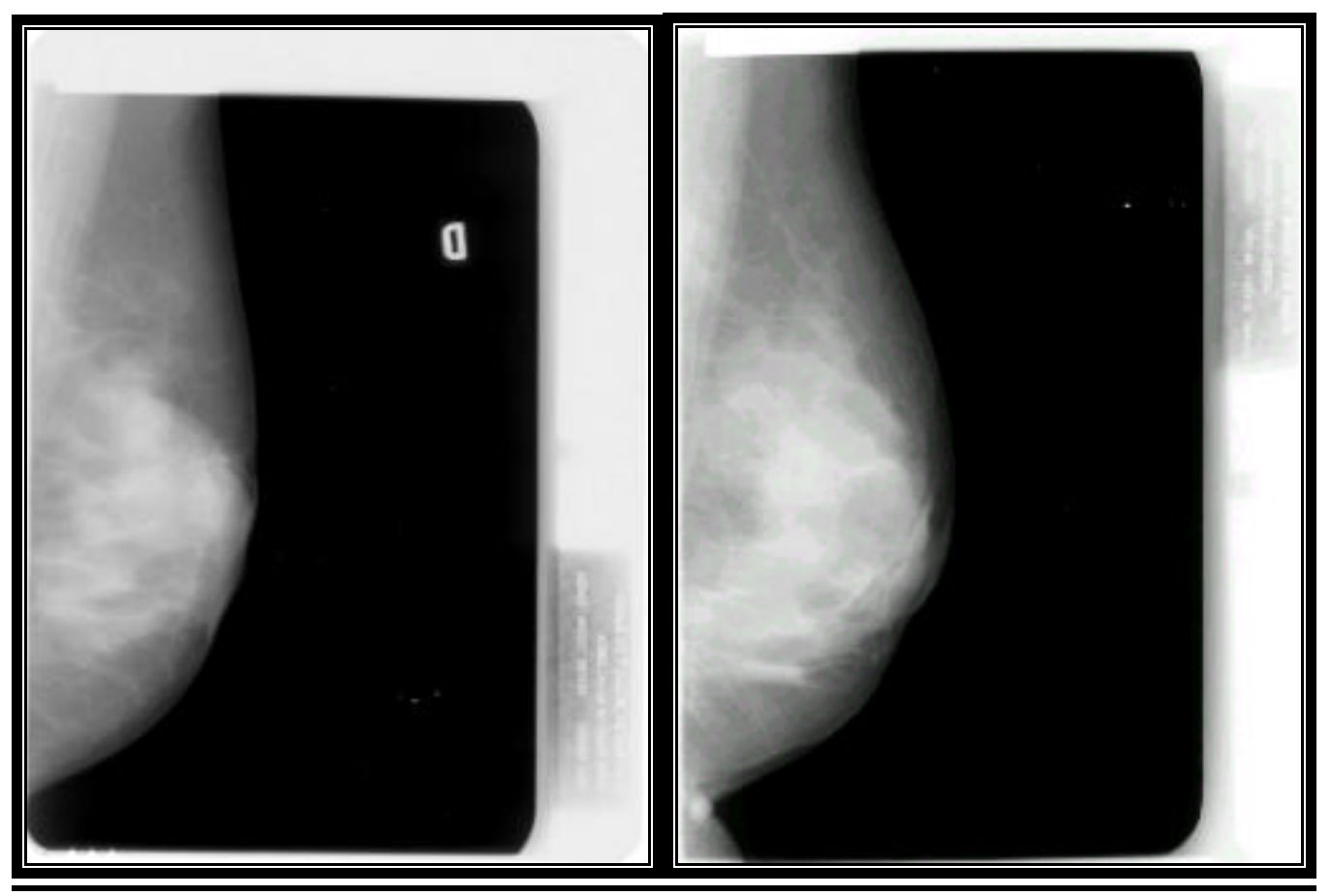

(a)

(b)

Figura 7.7-5 Exibição de dois mamogramas de uma das onze mulheres com a mesma técnica , sendo (a) Fase periovulatória;(b) Fase luteal , do mesmo ciclo. 


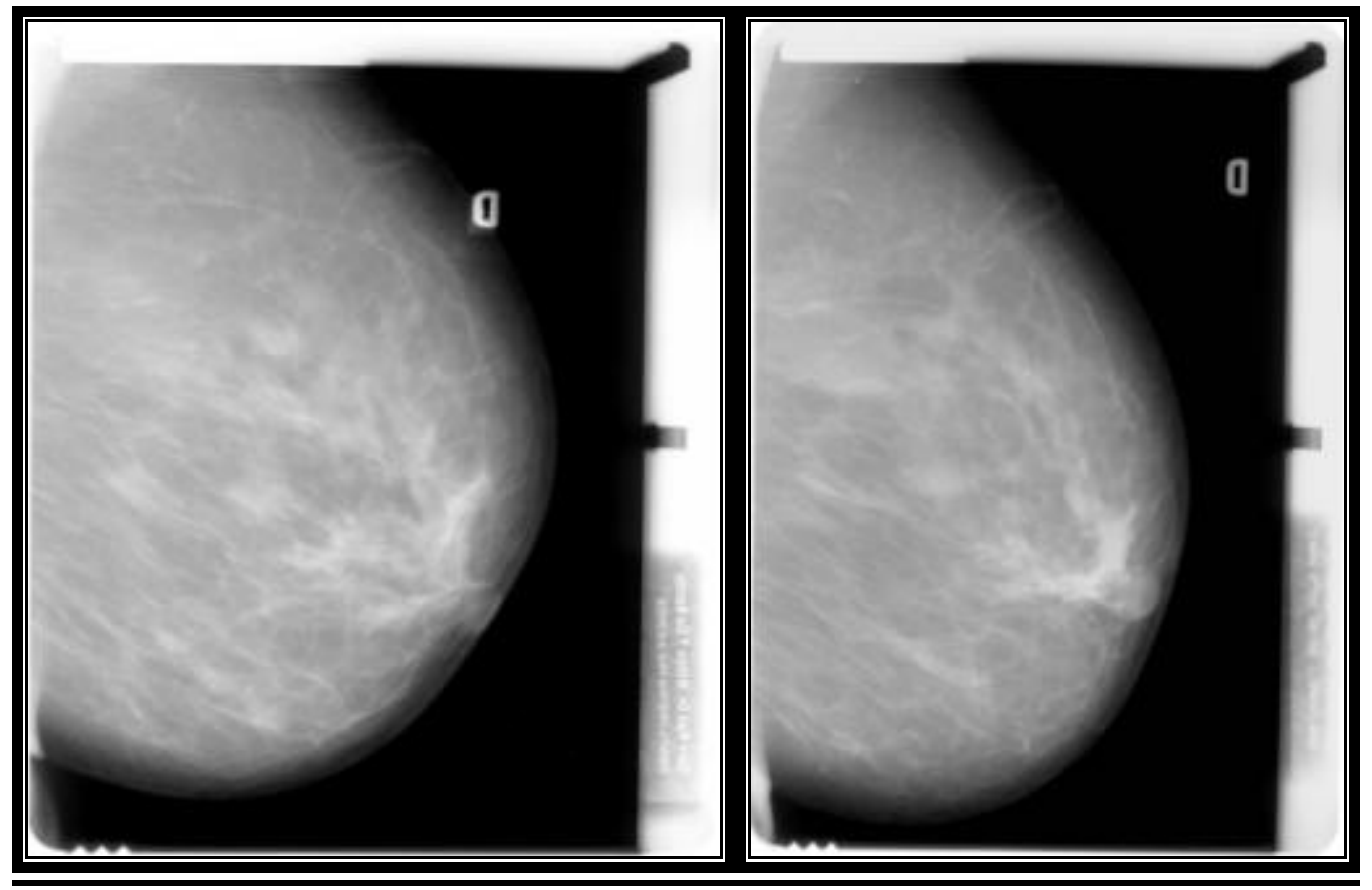

(a)

(b)

Figura 7.7-6 Exibição de dois mamogramas de uma das onze mulheres com a mesma técnica , sendo (a) Fase periovulatória;(b) Fase luteal , do mesmo ciclo.

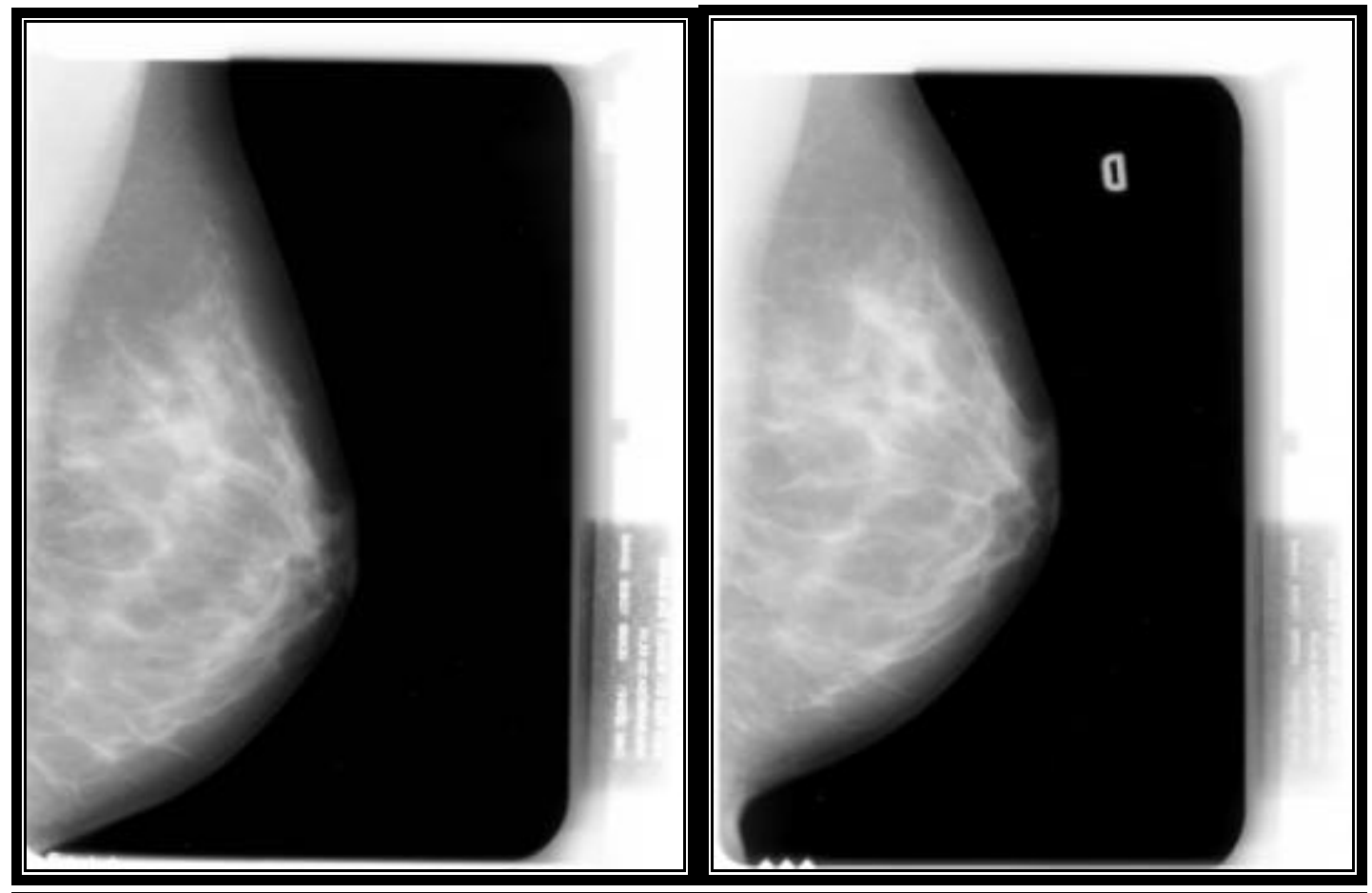

(a)

(b)

Figura 7.7-7 Exibição de dois mamogramas de uma das onze mulheres com a mesma técnica , sendo (a) Fase periovulatória;(b) Fase luteal, do mesmo ciclo. 


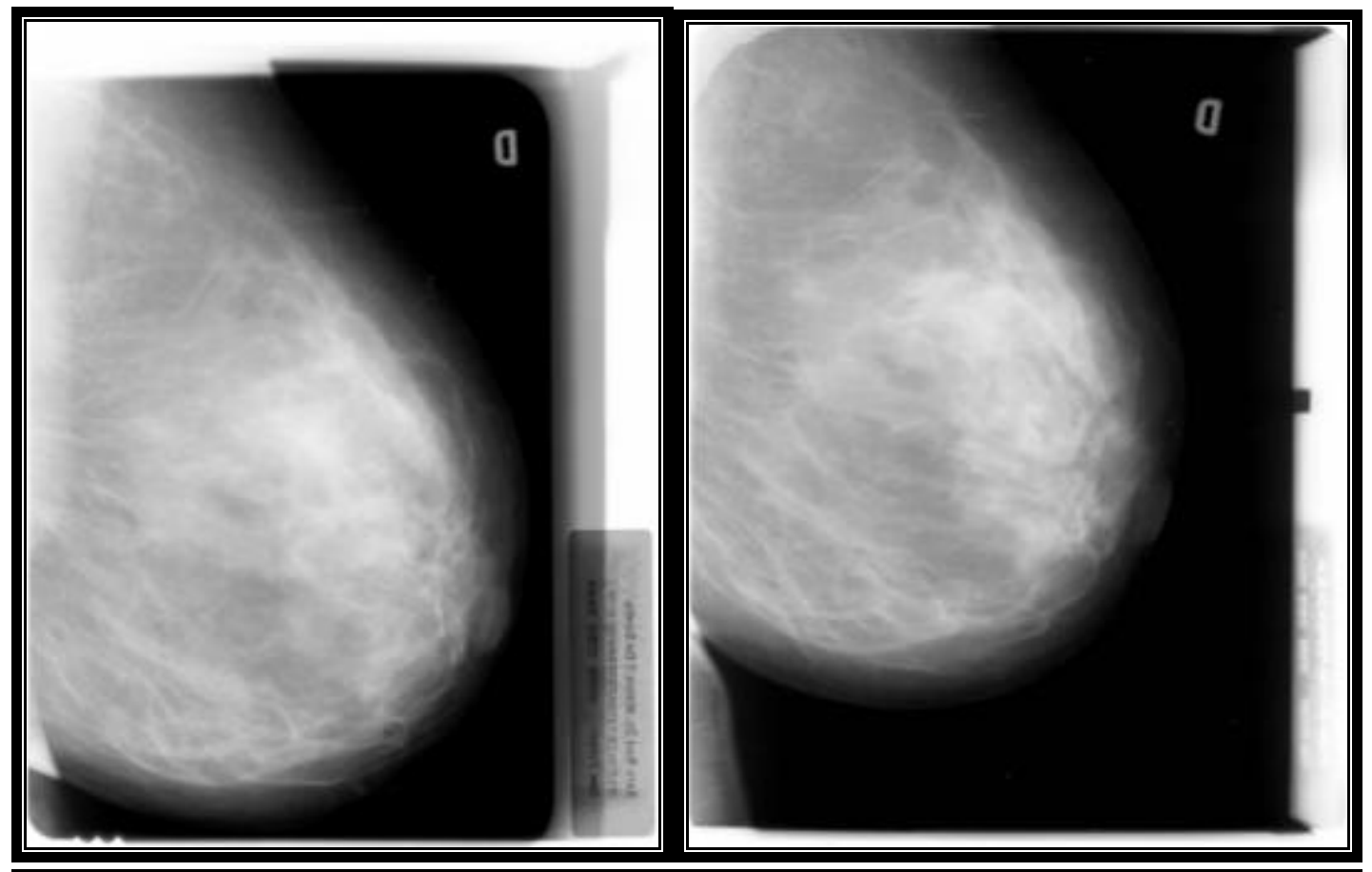

(a)

(b)

Figura 7.7-8 Exibição de dois mamogramas de uma das onze mulheres com a mesma técnica , sendo (a) Fase periovulatória;(b) Fase luteal , do mesmo ciclo.

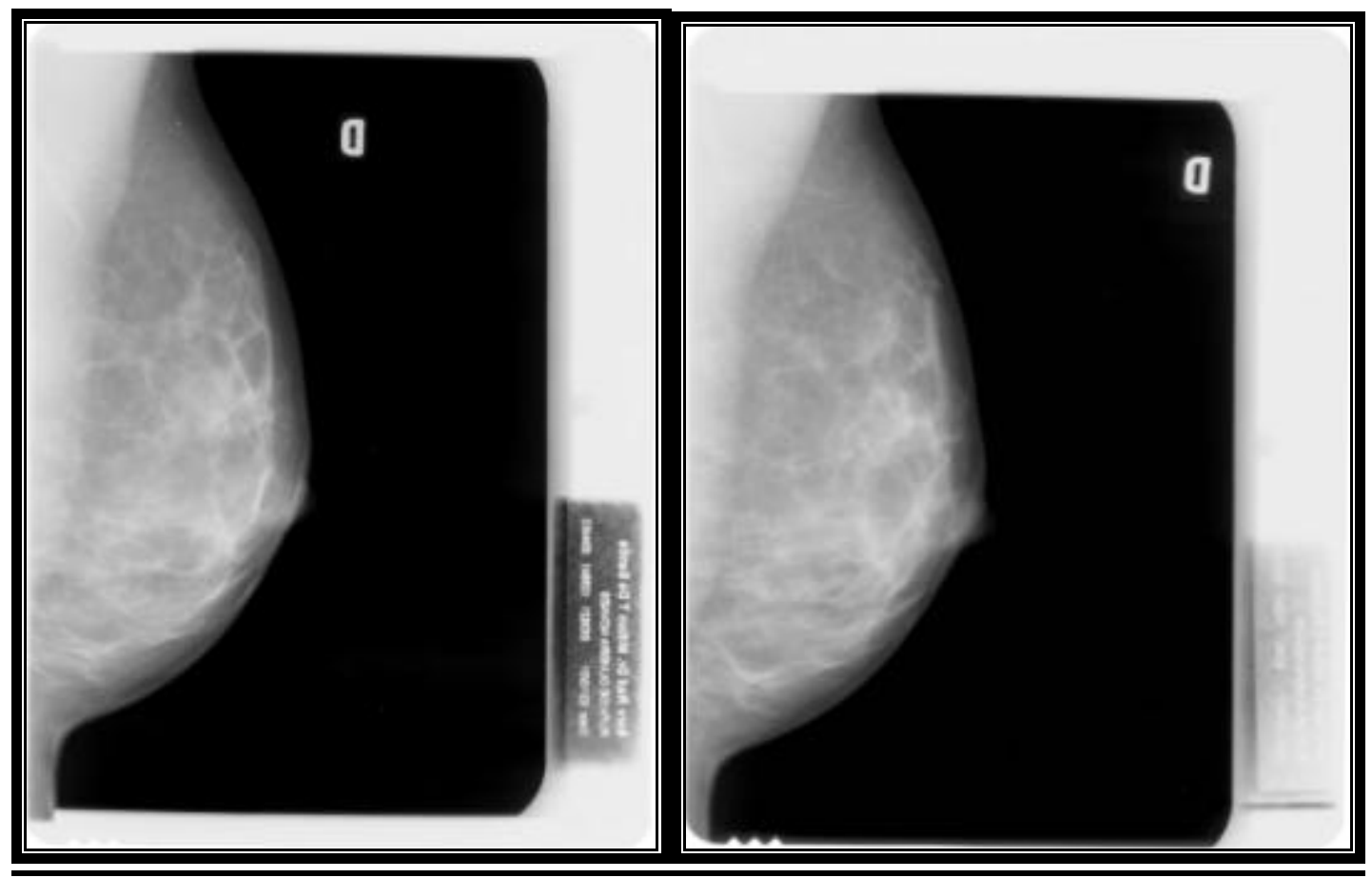

(a)

(b)

Figura 7.7-9 Exibição de dois mamogramas de uma das onze mulheres com a mesma técnica , sendo (a) Fase periovulatória;(b) Fase luteal , do mesmo ciclo. 


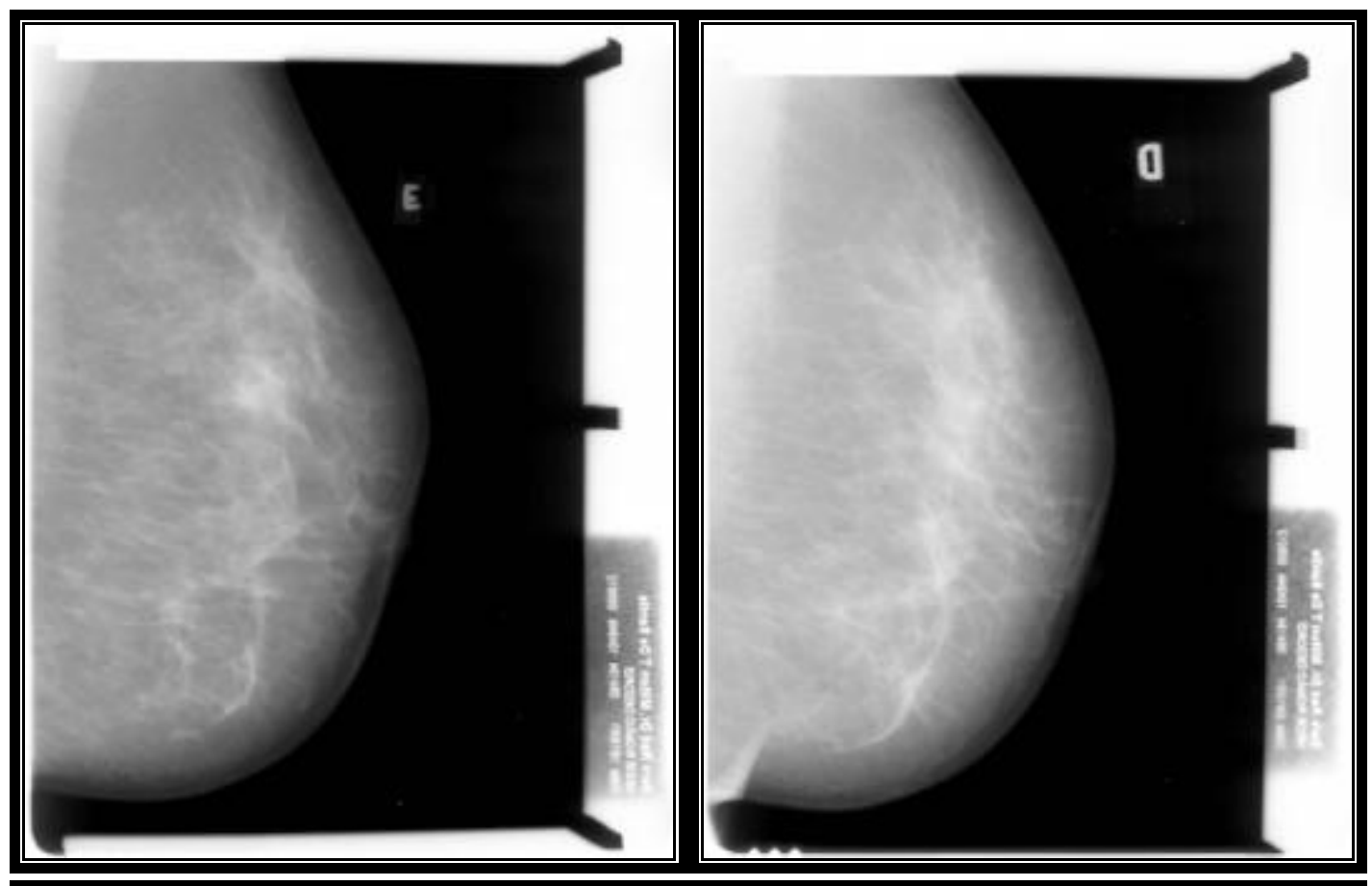

(a)

(b)

Figura 7.7-10 Exibição de dois mamogramas de uma das onze mulheres com a mesma técnica , sendo (a) Fase periovulatória;(b) Fase luteal , do mesmo ciclo.

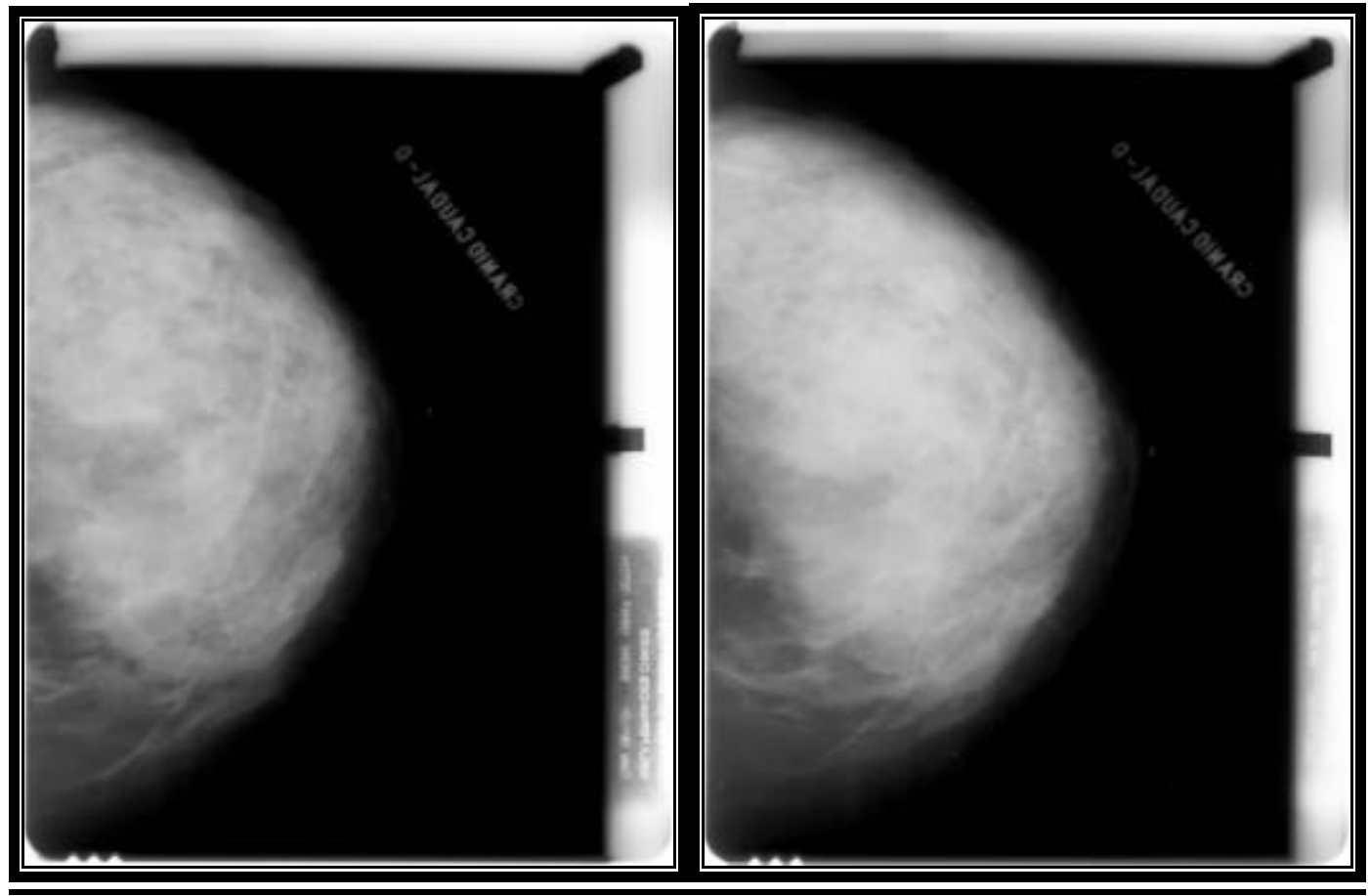

(a)

(b)

Figura 7.7-11 Exibição de dois mamogramas de uma das onze mulheres com a mesma técnica , sendo (a) Fase periovulatória;(b) Fase luteal , do mesmo ciclo. 


\section{8-Resultados do Histograma Feminino.}

Nessa seção, selecionaram-se 5 casos mais destacados em termos de variação de densidade entre os apresentados na seção anterior para analisar as diferenças agora em termos dos respectivos histogramas

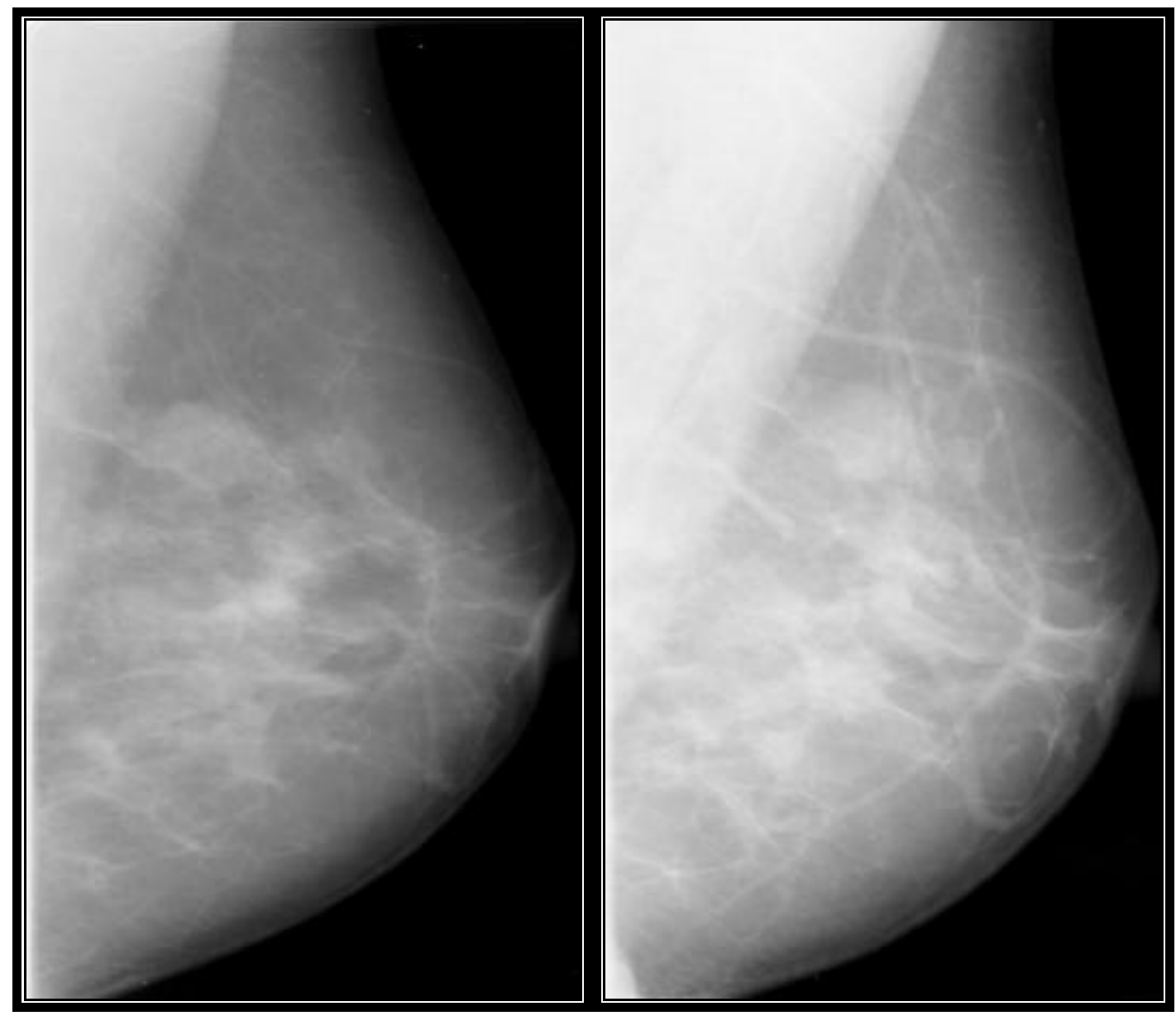

(a)

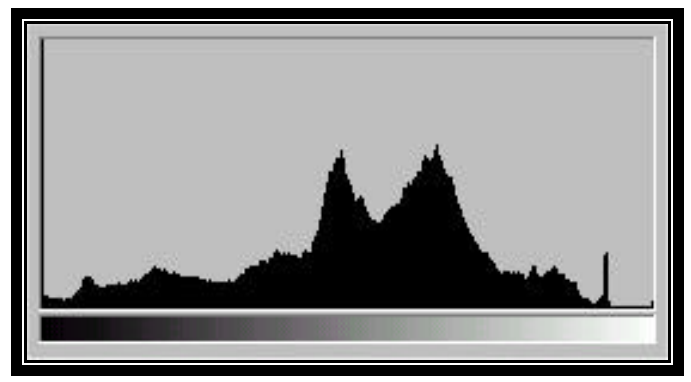

(c) (b)

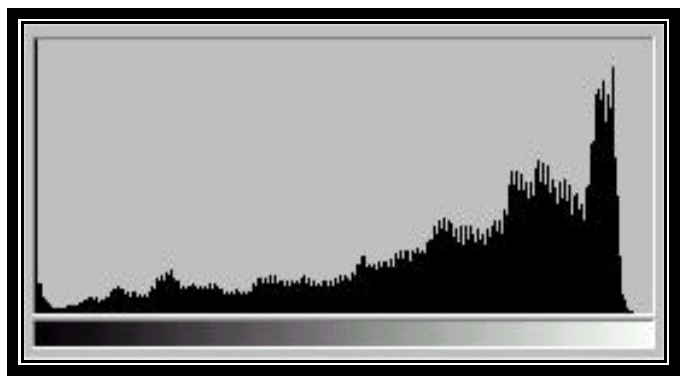

(d)

Figura 7.7-12 Mamografias (a) e (b) e seus respectivos histogramas (c) e (d) 


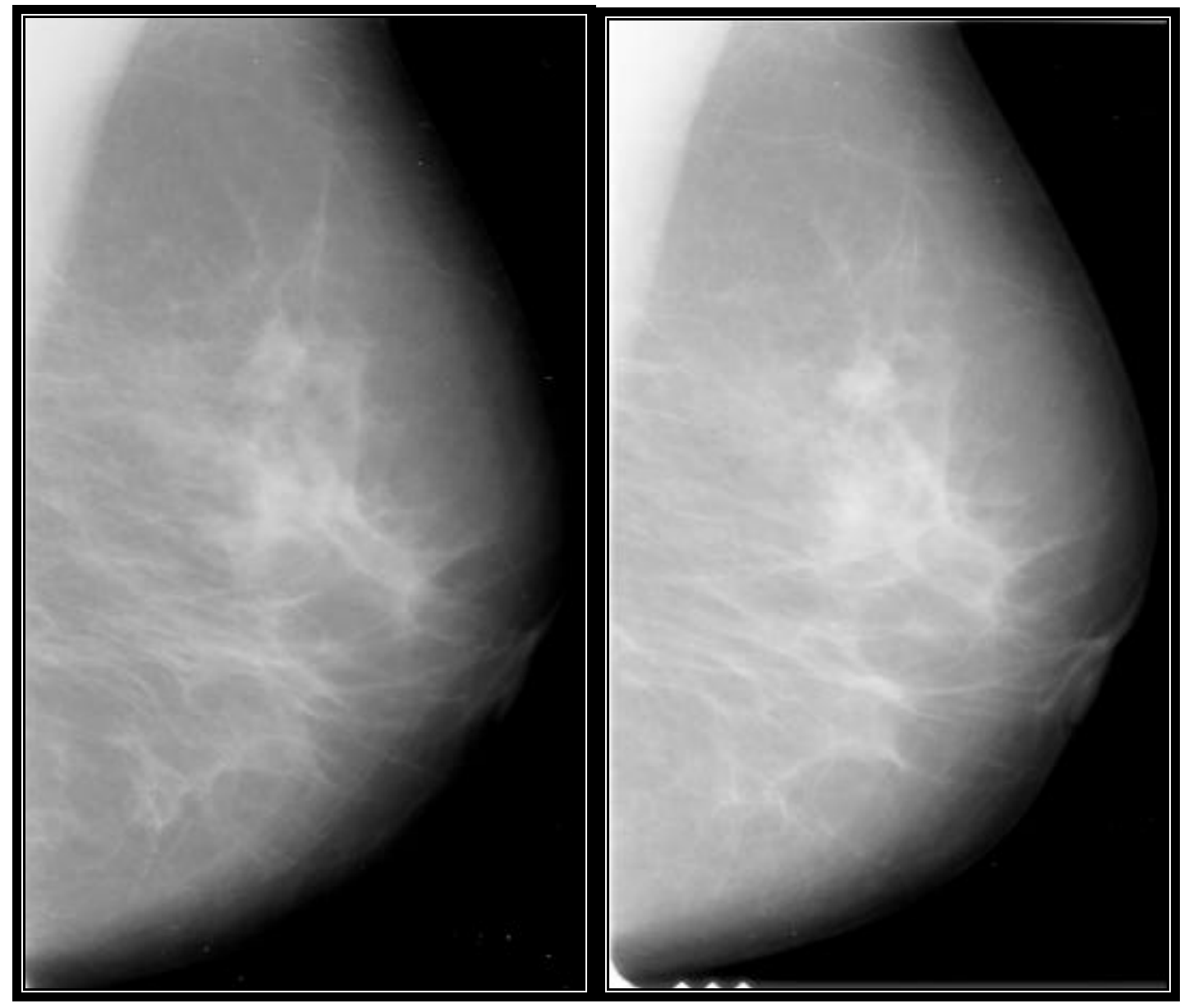

(a)

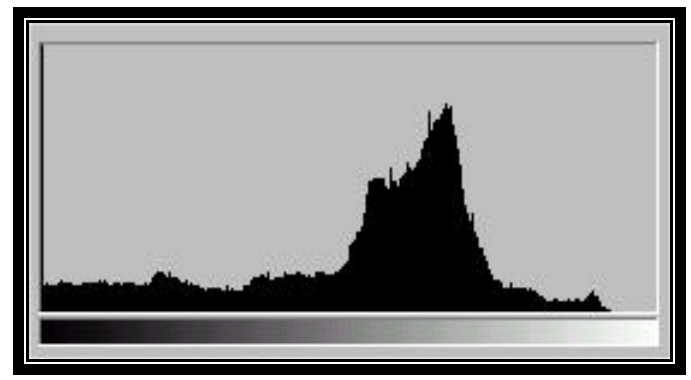

(c) (b)

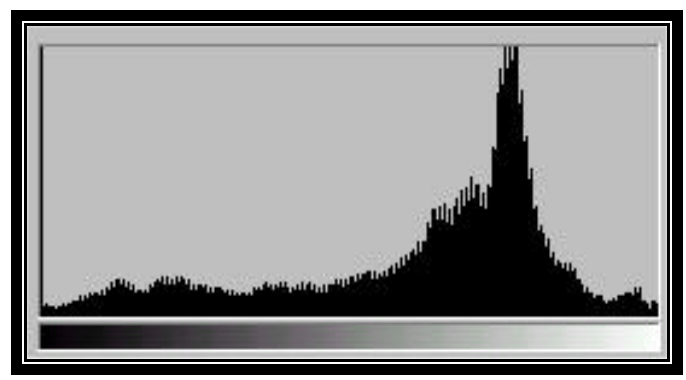

(d)

Figura 7.7-13 Mamografias (a) e (b) e seus respectivos histogramas (c) e (d) 


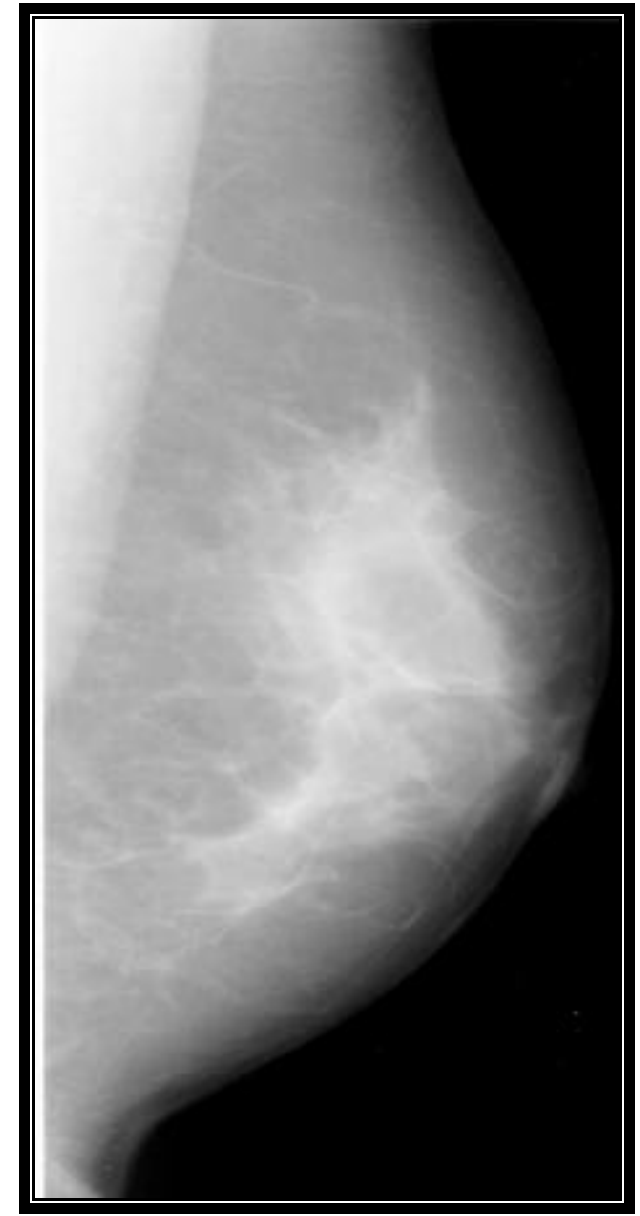

(a)

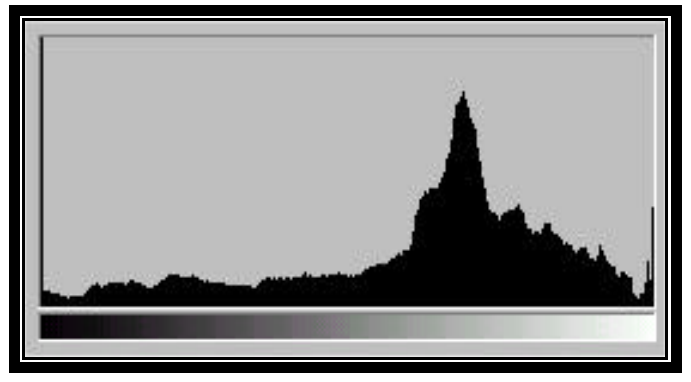

(c)

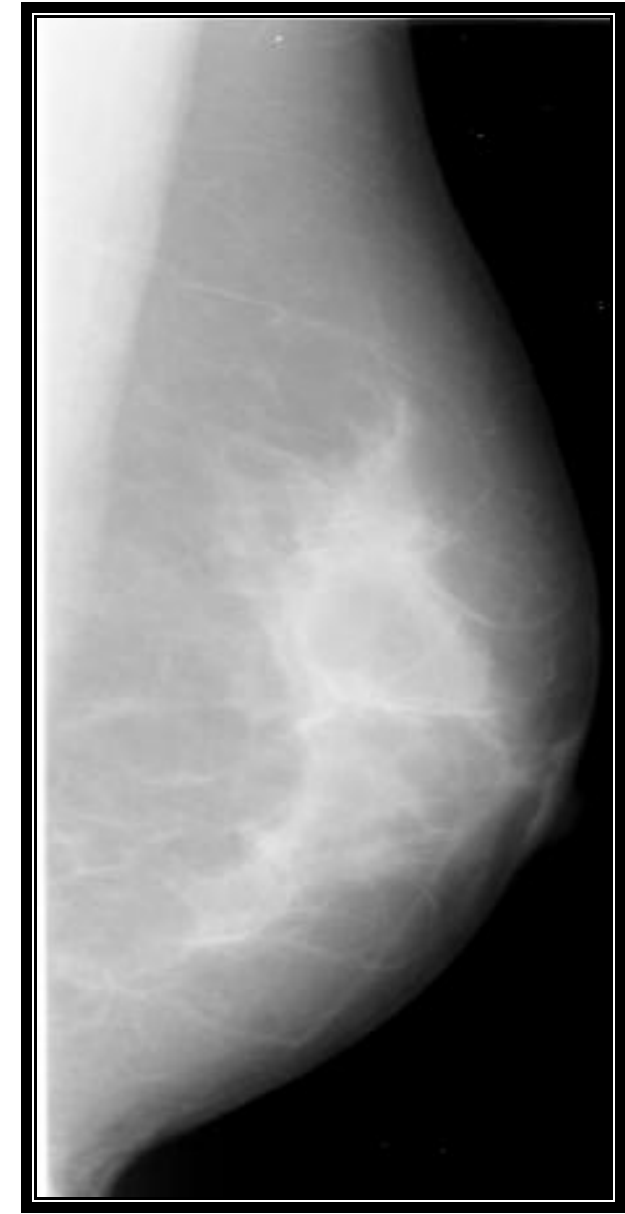

(b)

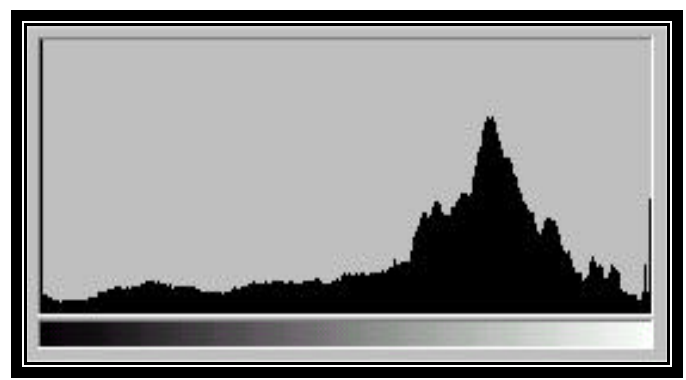

(d)

Figura 7.7-14 Mamografias (a) e (b) e seus respectivos histogramas (c) e (d) 


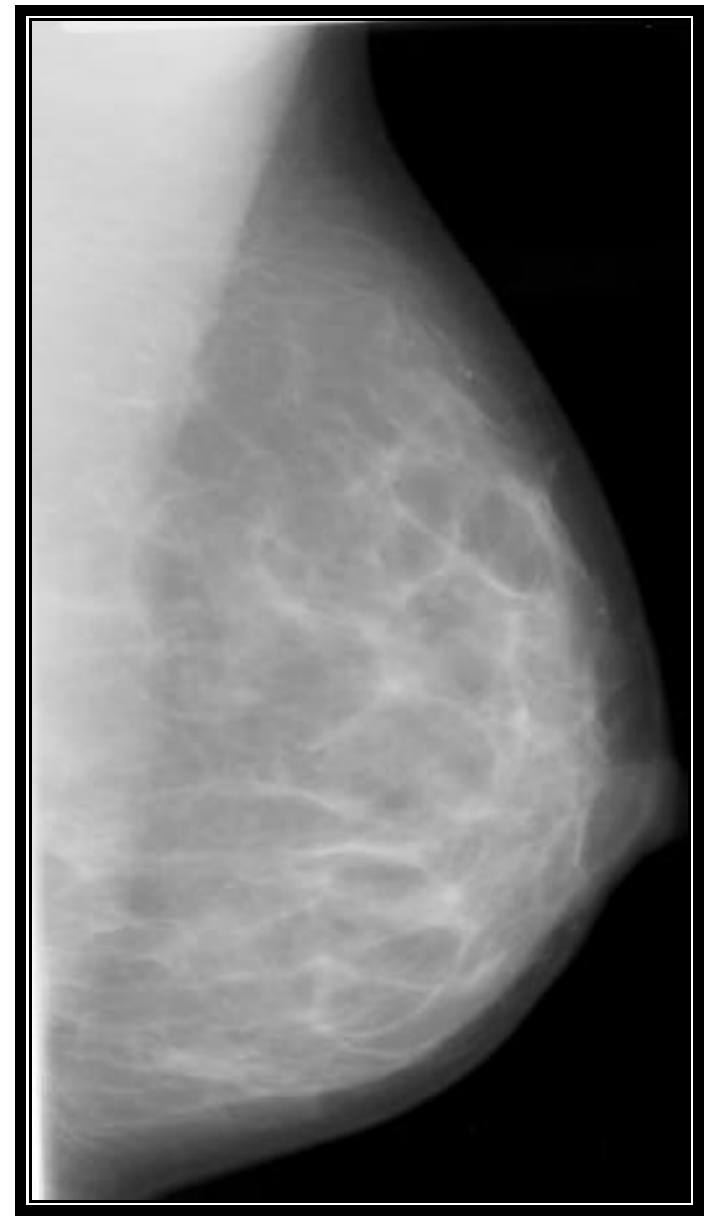

(a)

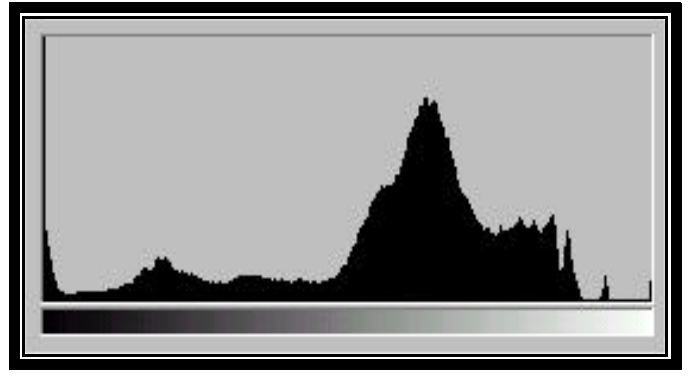

(c)

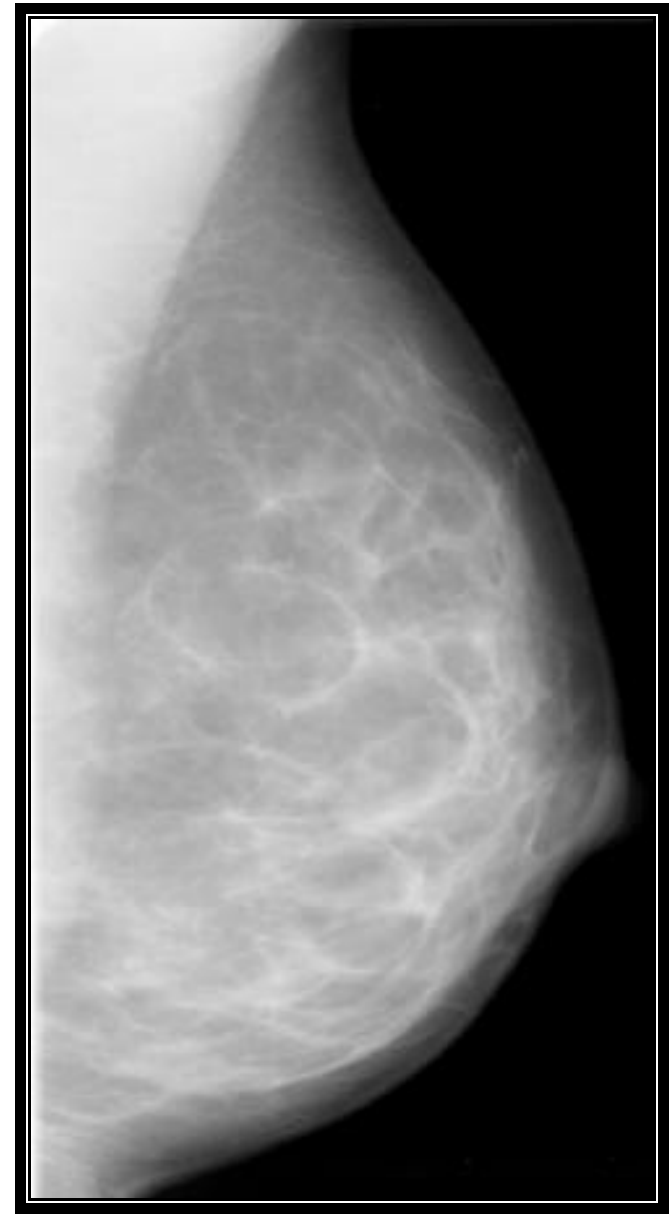

(b)

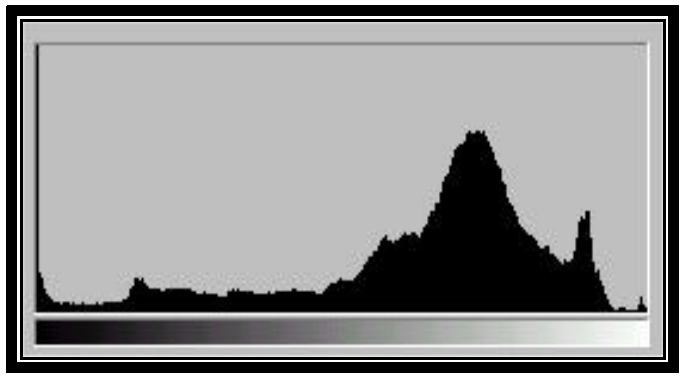

(d)

Figura 7.7-15 Mamografias (a) e (b) e seus respectivos histogramas (c) e (d) 


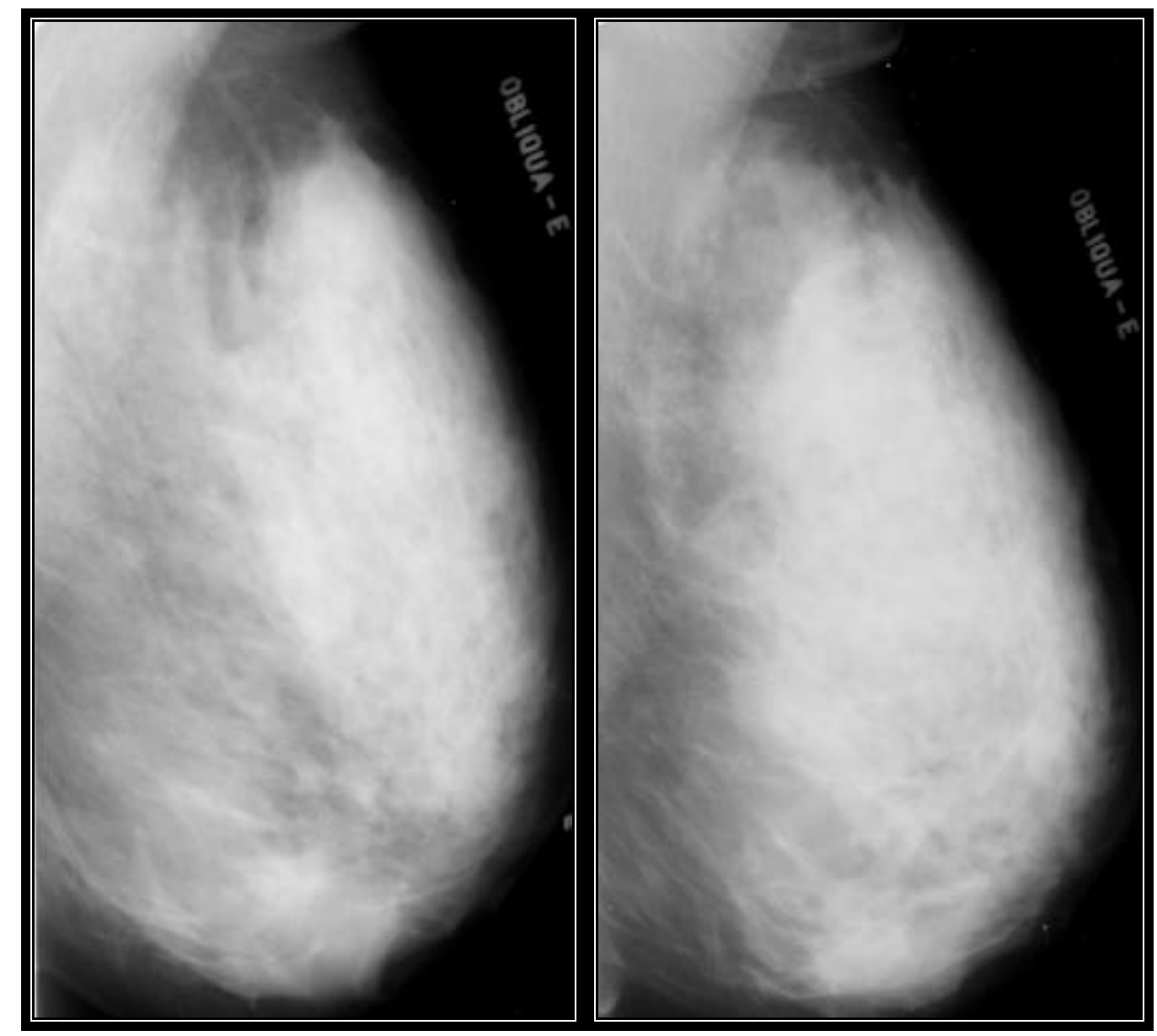

(a)

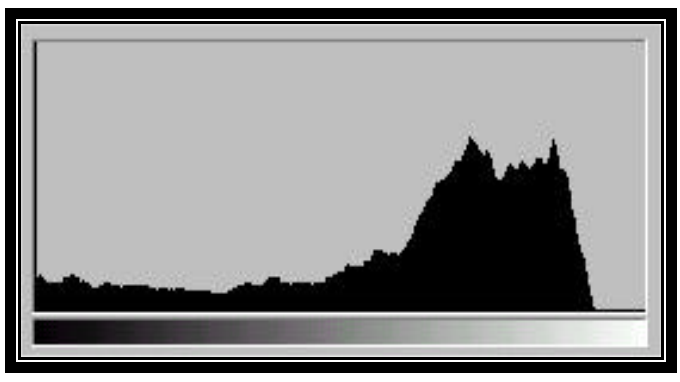

(c) (b)

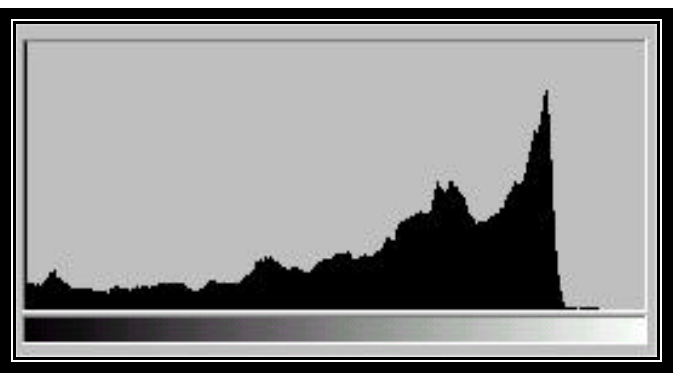

(d)

Figura 7.7-16 Mamografias (a) e (b) e seus respectivos histogramas (c) e (d) 


\subsection{ANÁLISE TEXTUAL DOS RESULTADOS}

O estudo teve a proposta de identificar na cabra um padrão de comportamento da densidade da mama ao longo de um ciclo estral, para assim se fazer uma avaliação dirigida dos mamogramas femininos Para isto mamografou-se o animal por 24 dias seguidos e colheu-se sangue e citologia por 40 dias seguidos. Assim no dia 06/06/01 iniciamos a colheita de citologia, sangue e tomadas de mamografias. No dia 29/06/01 encerramos as tomadas de mamografias, mas continuamos a coleta de sangue e citologia vaginal até o dia 10/07/01.

$\mathrm{Na}$ realidade esperava-se conseguir tomadas de dias típicos tanto da fase luteal como da fase folicular e ovulatoria, ou seja observar um ciclo fisiológico dos caprinos como pode ser visto na figura 6.1-1. Observando os resultados em gráficos da dosagem de estradiol e progesterona, pode-se dizer que trata se de um ciclo inteiro que foi anovulatório e um ciclo parcial que foi ovulatório. Isso configura um período atípico em que em vez de ser apresentado um ciclo fisiológico, ocorreu situação endócrina diversa. Por outro lado, pode-se dizer que a fase periovulatória, a fase luteal, e a fase folicular foram representadas pelo nosso experimento, porém em ciclos diferentes. Assim a fase folicular é a fase compreendida pelo período de 06/06/01 ao dia 20/06/01. Contudo pode-se observar que neste período houve um pico de secreção de progesterona, (exatamente no dia 15/06/01), que não se sustentou, mas houve a secreção de progesterona acima do basal e de uma forma súbita, logo houve a formação do corpo lúteo, e portanto a ovulação, que deve de ter ocorrido por volta do dia 10/06/01. Exatamente neste dia pela análise das imagens da figura a densidade cai drasticamente. É interessante observar a figura 7.4-2 (a) (dia 10/06/01) e a figura 7.4-1(d) referente ao dia 09/06/01, assim como a figura 7.4-2(b) referente ao dia 11/06/01. Note que a densidade cai de forma isolada e só neste dia 10. Inúmeros são os motivos que fizeram com que a secreção não se desse a contento, mas a mais pertinente é se imaginar que o "stress" do experimento bloqueou a secreção do hormonio uteinizante, o que tornou o corpo lúteo atrésico, do ciclo cuja ovulação se deu no dia 10/06/01

Todavia, conforme mostra o gráfico da figura 7.2-1, no dia 26/06/01 inicia se a secreção de progesterona que se mantém em níveis fisiológicos, tal como na homeostáse.Isso nos leva a supor que, houve ovulação por volta do dia 20-21/06/01. 
Novamente se registra a queda da densidade de forma drástica pelo que se pode observar nitidamente pelas figuras 7.4-4 (c) e (d) associados aos resultados objetivos da determinação percentual as densidades nos mamogramas conforme tabela-7.6-1, levam a supor que este comportamento esta relacionado com a ovulação

Estes dados nos levou a supor que este comportamento da densidade estaria relacionado com a ovulação.

Somente as mamografias dos dias 27-28/06/01 representam o período luteal , onde se nota aumento da densidade em relação aos dias ovulatorios.

Com este quadro, imaginamos que a densidade baixa refere-se á ovulação e a densidade alta ao período luteal. Ou ainda, os níveis altos de progesterona são compatíveis com densidade mamográfica alta, mesmo que não se verifique uma clássica fase luteal.

Escolhemos as mamografias femininas com esta diretriz em mente, e o que muito relevante, semelhante comportamento foi verificado nas 11 mulheres referenciadas averiguamos tal comportamento nas 11 mulheres referenciadas. Ou seja, a densidade mamográfica da imagem obtida na fase luteal foi maior do que a fase periovulatoria.

O gráfico do estrogênio é pouco representativo por estar com lacunas em períodos importantes, tal como antes da ovulação em que se registra uma secreção aumentada, como podemos ver na figura 6.1-1, onde se registra a secreção fisiológica dos caprinos.Este comportamento não pode ser averiguado por haver hiatos que implicam uma inconclusão, se houve ou não a secreção a contento. Contudo se o gráfico não representa efetivamente, ao menos ele esboça tal fenômeno, pois se pode notar tanto antes do dia 10 assim como antes do dia 20, esboços de picos de secreção de estrogênio. Este fato porem não é significativamente robusto para nos autorizar a afirmar que os hormônios progesterona e estradiol são antagônicos na promoção

da densidade. 


\section{Capítulo 8 - Conclusões/Discussão}

Os resultados mamográficos podem ser definidos de uma forma sintética, se for dito que: Na cabra o período ovulatorio é o período de menor densidade, e que o período da fase luteal é o período de maior densidade mamográfica. Por assim dizer, podemos observar que houve um aumento da densidade no dia 15 e neste dia vemos um aumento dos níveis de progesterona, sem contudo configurar a fase luteal. Pode se dizer ainda, que o aumento da densidade ocorre de forma imediata, e que isto pode ser observado em todos os momentos em que o nível de progesterona esta relativamente mais alto. $\mathrm{Na}$ mulher verificou se que a fase periovulatória oferece menor densidade em relação à fase luteal. Estes dados ฐ̃o concordantes, todavia não autoriza anunciar que o comportamento da densidade nas mulheres seja o mesmo ao verificado na cabra. Isto é, o experimento não foi pleno o suficiente para demonstrar que o comportamento da densidade verificado na cabra seja o mesmo ao longo do ciclo das mulheres. Mas permite dizer que, o comportamento de uma cabra foi o verificado e que na fase periovulatória e na fase luteal, 11 mulheres (100\% do recrutamento), tiveram concordância. Por outro lado, pode-se dizer que em 11 mulheres o comportamento entre a fase periovulatória e a fase luteal, foi o mesmo, ou seja, a fase periovulatória oferece menor densidade em ralação á fase luteal, estes resultados se verificam em uma cabra.

Podemos observar que a progesterona esta relacionada de forma direta ou indiretamente com o aumento da densidade.Pelo nosso experimento não podemos afirmar que o estradiol é responsável pela perda de densidade

$\mathrm{Na}$ realidade o experimento teve êxito no sentido de conhecer pela primeira vez, o comportamento da densidade de um animal durante o ciclo todo e este serviu de modelo para se deduzir os dias em que a densidade da mulher seria maior e o dia 
em que a densidade seria menor. Esta dedução foi comprovada pelas mamografias das mulheres. Ou seja, em 100\% das mamografias humanas examinadas com um universo de 11 , notou se que a fase periovulatória oferece menor densidade que a fase luteal. E assim pode ser anunciado que a fase periovulatória oferece menor densidade que a fase luteal, tanto nas mulheres como na cabra.

Os autores que estudaram a citologia e histologia da mama em relação às fases do ciclo menstrual e são partidários de que a mama sofre uma variação na celularidade nestas fases, concluem que na fase luteal, a celularidade é maior se analisado o ciclo todo. Este dado sugere que a densidade aumentada verificada por este experimento é causada pelo aumento da celularidade típico desta fase, constatado pelos autores acima referidos. Contudo, os dados provenientes das outras fases do ciclo tanto quanto a celularidade assim como quanto a densidade devem de ser mais pormenorizadamente estudados e correlacionados. É extremamente atrativa a idéia de que a celularidade exacerbada aumenta a densidade, fisicamente encontra respaldo, pois o comportamento do feixe é diferente se muda a celularidade e temos que admitir, que a diferença se da no sentido de subtração de fótons, o que concorda com o aumento da densidade verificada na cabra e nas mulheres, na fase luteal.

Este estudo, colabora com a idéia de que a mama varia a sua celularidade e os fenômenos verificados na clinica com aumento do volume pré-menstrual, deve se a um aumento da celularidade e não ao aumento do ingurgitamento como querem alguns. Pois a fase luteal precede a fase menstrual, e na fase pré-menstrual, onde se verifica histologicamente o aumento da celularidade e infiltrado linfocitário é a fase onde se verificou o aumento da densidade. Assim podemos dizer que este estudo aumenta as evidencias de que os fenômenos clínicos sentidos na fase pré-menstrual, deve se a um aumento da celularidade e não a um aumento do ngurgitamento, pois parece pertinente imaginar que $\mathrm{o}$ aumento do ingurgitamento causaria uma diminuição da densidade e não um aumento da densidade, como se verifica na fase luteal.

Menos respaldo encontra o anúncio de que a variação da densidade deve se a uma variação hormonal, já que as repercussões cito/histológicas ainda não se reveste de um apoio nosológico consensual. 
Então estas variações notadas na cabra e na mulher são averiguações experimentais que ainda no momento não se pode associá-las a fatores, visto que falta a demonstração cito/histológica, assim como a correlação hormonal.

É importante que se realize trabalhos que demonstrem melhor as variações cito/histológicas, de forma a se ter a tipologia das fases do ciclo menstrual definitivamente delineadas, dentro de uma padrão fisiológico. Estabelecido estes aspectos, deverá de se checar o efeito no campo hormonal para se correlacionar causa e efeito nesta tipologia. Que em terceira instancia deverá de se estudar o efeito das endocrinopatias na densidade mamográfica, visto que as evidencias de atuação de hormônios tanto sexuais como metabólicos é patente na mama. Estes estudos serão de grande utilidade, pois é tentadora a idéia de que as pacientes com hipertireoidismo, assim como as diabéticas, as portadoras de Doença de Addison etc, receba um trato técnico diferenciado, quando se investigar a mama através do mamógrafo.

$\mathrm{Na}$ realidade, os mamógrafos atuais operam em nível de energia muito baixo, em faixas em que os coeficientes de atenuação s̃o maiores, visto que os tecidos que compõe a mama têm coeficientes de atenuação próximos. Deste aumento da sensibilidade do instrumento, redunda uma variação do contraste, diante da mínima variação dos tecidos. Esta vertente da problematização é importante, pois o objeto a ser mamografado além de variar com o ciclo menstrual deverá de variar, teoricamente, em nível de doenças endócrinas, que tem repercussões na tipologia normal dos tecidos da mama.

Parece que a variação da densidade da mama ao longo de um ciclo menstrual, é a variação mais flagrante e registrada parcialmente.Os novos estudos deverão de se ater no entendimento destas variações em outras instancias, quando as endocrinopatias são apenas um campo de estudo.

Outra face deste estudo é o entendimento do comportamento das lesões histológicas tanto malignas como benignas frente a fatores hormonais, no que se refere à variação da densidade. Visto que, o contraste pleiteado pelo mamógrafo, é entre uma lesão e o tecido normal. São os dois elementos envolvidos que carecem de estudos mais decisivos, para de fato se saber onde e quando perante variações hormonais o contraste oferece maior visibilidade. Fisicamente será maior na medida 
em que a diferença do coeficiente de atenuação foi maior entre duas estruturas que se deseja formar o contraste. Portanto, é fundamental se conhecer o comportamento dos dois elementos envolvidos (tecido normal /tecido lesado) quanto a densidade, para se prever onde será maior o contraste. Aqui, o assunto toma um contorno extremamente amplo, pois nosologicamente trata se da comparação visual entre as variantes patológicas, com as variantes fisiológicas, no que tange à variação da densidade mamográfica. 


\section{Referências Bibliográficas}

BLAND, K.I; COPELAND. E. M(1994). A Mama: Tratamento Compreensível das Doenças Benignas e Malignas. São Paulo. Manole.

BATTERBY et al, (1991). Influence of Menstrual of Cycle, Parity and Oral Contraceptive use on Steroid Hormone Receptoress in Normal Breast. Br. Journal Cancer.

BOGLIOLO, L. (1972). Patologia. Rio de Janeiro. Guanabara Koogman.

BRZAKOVIC, D.; LUO, X.M.; BRZAKOVIC, P. (1990). An approach to automated detection of tumors in mammograms. IEEE Transactions on Medical Imaging, v.9, n.3, p.233-241, sep.

BURKE, M.W. (1996). Image Acquisition. Chapman \& Hall, Oxford.

CHAN, H.-P.; DOI, K.; VYBORNY, C.J.; LAM, K.-L.; SCHMIDT, R.A. (1998). Computer-aided detection of microcalcifications in mammograms: methodology and preliminary clinical study. Investigative Radiology, v.23, n.9, p.664-671, sep.

CHAN, H.-P.; NIKLADSON, L.T.; IKEDA D.M.; LAM, K.-L.; ADLER, D.D. (1994). Digitization requirements in mammography: effects on computer-aided detection of microcalcifications. Medical Physics, V.21, n.7, p. 1203-1211, jul.

CHEW et al.(1995). Mammographically Negative Breast Cancer at the Strathfield Breast Centre. Strathfield Breast Center.

CURRY III, T.S.; DOWDEY, J.E.; MURRY, R.C. (1990). Christensen's Physics of Diagnostic Radiology. 4.ed. Philadelphia, Lea \& Febiger. 
DAVIES, D.H.; DANCE, D.R. (1990). Automatic computer detection of clustered calcification in digital mammograms. Physics in Medicine and Biology, v.35, n.8, p.1111-1118.

DHAWAN, A.P.; ROYER, E.L. (1988). Mammographic feature enhancement by computerized image processing. Computer Methods and Programs in Biomedicine, v.27, p.23-35.

FANGER H, Ree HJ: Cyclic Changes of human mammary gland epithelium in relation to the menstrual cycle:An ultrastrutural study. Cancer 34:574-585, 1974.

FERGUSON et al.(1992). Changes in the Extracellular Matrix of the Normal Human Breast During the Menstrual Cycle.Cell Tissue Res.

FRANTZ AG: The breast. In Textbook of Endocrinology.Edited by RH Willians.Philadelphia, WB Saunders, 1981,pp 400-402

GOING et al. (1998). Proliferative and Secretory Activity in the Human Breast During Natural and Artifial Menstrual Cycles. American Journal of Pathology.

GONZALEZ, F. T; GÓMEZ, A T. (1986). Tratamiento del Cancer Del Mama. Barcelona. Salvat.

GONZALEZ, R.C.; WOODS, R.E. (1992). Digital Image Processing, $3^{\text {rd }}$ Ed., Addison- Wesley, Massachusetts.

GRAY, F. R. S. H; GOSS, A . B. C. M. (1977). Anatomia. Rio de Janeiro. Guanabara Koogman.

HAAGENSEN, C. D. (1987). Enfermedades de la Mama. Buenos Aires. Panamericana.

HAUS, A.G.; YAFFE, M.J. (2000). Screen-film and digital mammography: image quality and radiation dose considerations. Radiologic Clinics of North America, v.38, n.4, p.871-898. 
ISHIDA, M.; DOI, K.; LOO, L.N.; METZ, C.E.; LEHR, J.L. (1984). Digital image processing: effect on detectability of simulated low-contrast radiographic patterns. Radiology, v.150, p.569-575.

JI, T.L.; SUNDARESHAN, M.K.; ROEHRIG, H. (1994). Adaptive image contrast enhancement based on human visual properties. IEEE Transactions on Medical Imaging, v.13, p.573-584.

JIANG, Y.; NISHIKAWA, R.M.; PAPAIOANNOU, J. (1998) Requirement of microcalcification detection for computerized classification of malignant and benign clustered microcalcifications. In: SPIE IMAGE PROCESSING. Proceedings, v.3338.

LAI, S.M.; LI, X.; BISCHOF, W.F. (1989). On techniques for detecting circumscribed masses in mammograms. IEEE Transactions on Medical Imaging, v.8, p.377-386.

MALBERGER et al. (1986). Cellular Changes in the Mammary Gland Epitheliun During the Menstrual Cycle. Acta Cytologic.

MARQUES FILHO, O.; VIEIRA NETO, H. (1999). Processamento Digital de Imagens, Brasport Livros e Multimídia LTDA., Rio de Janeiro (RJ).

MEYER FRANÇOIS; BRISSON JACQUES; MORRISON,ALAN S.BROWN JAMES B.. (1986). Endogenous Sex Hormones, Prolactin, and Mammographic Fectures of Breast Tissue in Premenopausal Women.Jnci, Vol 77.

MONTENEGRO, M. R; FRANCO, M.(1992). Patologia Processos Gerais. São Paulo. Atheneu.

NISHIKAWA, R.M.; GIGER, M.L.; DOI, K.; METZ, C.E.; YIN, F.F.; VYBORNY, C.J.; SCHMIDT, R.A. (1994). Effect of case selection on the performance of computer-aided detection schemes. Medical Physics, v.21, p.265-269.

NOVAK, E. R; JONES, G. S.; JONES JR, H. W. (1977). Tratado de Ginecologia. Rio de Janeiro. Guanabara Koogan. 
OLSON,BEATRIZ R;FORMAN,R.MICHELE, LANZA, ELAINE;. (1996). Relation Between Sodium Balance and Menstrual Cycle Symptomsin Normal Women. Annals of Internal Medicine.

OLSSON,H;JERNSTROM,H.;ALM,P.;KREIPE,H.;INGVAR,C.;JONSSON,. 1996). Proliferation of the Breast Epithelium in Relation to Menstrual Cycle Phase, Hormonal Use, and Reproductive Factors. Kluwer Academic Publishers.

PIATO, S. (1979). Diagnostico e Terapêutica em Mastologia. São Paulo. Atheneu.

PORTER JC: Hormone regulation of breast developement and activity. J Invest Dermatol.63; 85;92, 1974

QIAN, W.; ClARKE, L.P.; ZHENG, B.; KALlERGI, M.; CLARK, R. (1995) Computer assisted diagnosis for digital mammography. IEEE Engineering in Medicine and Biology, v.14, n.5, p.561-569.

RAM, G. (1982). Optimization of ionizing radiation usage in medical imaging by means of image enhancement techniques. Medical Physics, v.9, p.733-737.

ROBBINS SL, Contrans RS , Kumar V: Pathologic Basic of Diseases.Philadelphia, WB Sauders , 1984 pp 1165-1166

ROSS, N. H; REITH, E. J; RONRELL, L.J.(1993). Histologia: Texto e Atlas. Colombia. Panamericana.

ROUQUAYROL, M. Z. (1988). Epidemiologia e Saúde. Rio de Janeiro. Medsi.

RUSS, J.C. (1992). The Image processing handbook. $2^{\text {nd }}$ Ed., Boca Raton, CRC Press Inc.

SICKLES, E.A. (1982). Mammographic detectability of breast microcalcifications. American Journal of Radiology, v.139, p.913-918.

SYMMERS WS: (1978), Systemic Pathologic. Edinburgh, Churchill Livingstone, 1978, pp 1960-1965. 
SODERQVIST. (1997). Proliferation of Epithelial Cells in Healthy Women During the Menstrual Cycle. Am J Obstetr. Gynecol.

SPEROFF, L.(1999). Role of Progesterone in Normal Breast Physiology. Journal of Reproductive Medicine.

STEDMAN. (1979). Dicionário Médico. Rio de Janeiro. Guanabara Koogman.

TESTUT, L; LATARJET, A .(1978). Tratado de Anatomia . Barcelona . Salvat.

URIBURU, J. V. (1986). La Mama: Estructura, Patologia, Diagnóstico y Tratamiento. Buenos Aires. Lopez.

VERONESI, U; LUINI, A; ANDREOLI, C.(1992). A conservação da Mama. São Paulo, Icone

VIEIRA, A.V. Mamografia de Alta Resolução, Centro de Medicina Nuclear da Guanabara, http://www.hps.com.br/medicinanuclear/mamoalta.htm (01/03/2002).

VOGEL,PATRICK M; GEORGIADE, NICHOLAS;FETTER, BERDARD F. G.(1981). The Correlation of Histologic Changes in Human Breast with the Menstrual Cycle. NOI( National Cancer Intitute).

WATSON,R.J; EYDEN,B.P; HOWEL, A.. (1988). Ultrastructural Observations on the Basal Lamina in the normal Human Breast. Journal Anatomy.

WINSBER, G.F.; ELKIN, M.; MACY, J.R.J.; BORDAZ, V.; WEYMOUTH, W. (1967). Detection of radiographic abnormalities in mammograms by means of optical scanning and computer analysis. Radiology, v.89, p.211-215. 


\title{
Glossário
}

\author{
Abscesso - Coleção circunscrita de pus \\ Adenose - Proliferação das células epiteliais. \\ Axilares - Ponto externo em que os membros de certos animais se unem ao \\ corpo
}

Bile - Líquido esverdeado, amargo e viscoso secretado pelo fígado.

Bilobulado -Que tem dois lóbulos.

Biopsia - Procedimento invasívo, feito em vivo, que se visa fragmento de tecido para avaliação microscópica.

Bioquímica - Ramo da química que trata de reações passada nos seres vivos

Carcinoma - Tumor de células epiteliais com capacidade de invadir e metastizar .

Cirrosa - Endurecida, amarelada.

Cistos -Lesão expansiva que se caracteriza por ser oca.

Citológico - Estudo da estrutura e função da célula

Coagulativo - Transformação do fluido ao sólido ou gel, que ganho solidez , que coagula.

Couraça -Tipo de câncer de mama que compromete a pele de forma caracaterística.

Depilação - Ato ou efeito de depilar.

Derrame Papilar - Líquido exteriorizado pela área crivosa do mamilo de forma espontânea ou estimulado.

Displasia - Distúrbio do crescimento dos tecidos.

Distrófica - Distúrbio da nutrição, que pode ser usado para se referir à distúrbio de parte do corpo, orgão ou sistema. Esta relacionada à situação assumida por deficiência de constituinte bioquímico, hormonio, vascularização ou inervação. 
Doença de Mondor - Doença da mama, quee se caracteriza por tromboflebite e outros sinais clínicos.

Ductal - Relativo aos ductos, estrutura canalicular.

Eczema - Dermatose que se caracteriza por ser dotada de crostas.

Edema - Tumefação em decorrência do aumento da presença de água nos tecidos.

Embolização -Situação de migração de material estranho ou próprio do sangue ou nos vasos sanguíneos ou linfáticos.

Encapsulado - Aquilo que tem cápsula, presente nos tumores benignos.

Epidemiologia - Estudo da difusão e propagação de uma doençana comunidade, especialmente infecciosa e epidêmica.

Epiteliose - Proliferação de células epiteliais.

Eritematosa - Vermelhidão da pele causado por fenômenos vasos-motores.

Esquirrosa - Endurecido, tipo de carcinoma mamário que se caracteriza por um endurecimento notado clinicamente.

Esteatonecrose - Lesão redundante da necrose do tecido gorduroso.

Esteroide - Derivados do ciclopentanofenatrenos

Estroma - Parte estrutural de um orgão.

Etiológico - Estudo da origem das coisas.

Fiboadenoma - Neoplasia do tecido glandular, onde no estroma é notável a presença de fibroblastos.

Fibrocística - Lesão cística circundada por tecido fibroso.

Galopante -Usado para referir à evolução rápida de doença.

Glândulas - Conjunto de células destinadas a secretarem determinadas substâncias.

Hematoma - Coleção de sangue que confere aparência de tumor.

Hiperplasia - Distúrbio de crescimento dos tecidos caracterizados por aumento.

Humores - Líquidos extracelulares do organismo: Linfa e sangue

Infartado - Situação em que a oferta de sangue não é suficiente.

Isquêmica - Situação em que a oferta de sangue oxigenado é insuficiente.

Lactocele - Coleção de leite, confinado a um cisto por obstrução do ducto. 
Ligadura - Ato de amarrar vasos sangrantes durante ato cirúrgico.

Linfática - Sistema de vasos que se comunica com o sistema sanguíneo, que circula linfa, por onde circula linfócitos e outras células.

Mastectomia - Retirada cirúrgica parcial ou total da mama.

Mastite - Termo genérico que sugere processo inflamatório na mama.

Miocutâneo - Algo relativo àmúsculo e pele.

Morbidade - Relativo a doença

Mortalidade - Relativo à quantidade de mortes.

Nefropatia - Doença dos rins, que acomete os nefrons.

Neoplasia - Crescimento anormal do tecido, decorrente de multiplicação celular.

Nódulo - Massa circunscrita de tecido orgânico.

Ooforectomia - Exerese cirúrgica dos ovários.

Organelas - Qualquer parte da célula com função determinada.

Papiro -Grande erva da família das Ceperaceas, cujas folhas forneciam material sobre o qual se esccrevia.

Papilomas -Neoplasia epitelial benigan de formato viloso.

Prognostico - Juízo medico baseado do diagnostico e nas possibilidades terapêuticas.

Patológico - Caráter doentio de algo relacionado aos seres vivos.

Proliferação - Crescimento através do aumento do número de células.

Plasma - Resultado da subtração dos elementos figurados do sangue.

Parênquima -Parte funcional de um orgão.

Recidiva - Reaparecimento de uma doença.

Retromamario - Imediatamente atraz da mama, espaço compreendido entre a glândula propriamente dito e a aponeurose.

Tumorectomia - Retirada cirúrgica do tumor. 